\title{
WestVirginiaUniversity
}

THE RESEARCH REPOSITORY @ WVU

Graduate Theses, Dissertations, and Problem Reports

2001

\section{Numerical modeling of chemical recovery from black liquor char}

Dharmarajan Hariharan

West Virginia University

Follow this and additional works at: https://researchrepository.wvu.edu/etd

\section{Recommended Citation}

Hariharan, Dharmarajan, "Numerical modeling of chemical recovery from black liquor char" (2001). Graduate Theses, Dissertations, and Problem Reports. 1159.

https://researchrepository.wvu.edu/etd/1159

This Thesis is protected by copyright and/or related rights. It has been brought to you by the The Research Repository @ WVU with permission from the rights-holder(s). You are free to use this Thesis in any way that is permitted by the copyright and related rights legislation that applies to your use. For other uses you must obtain permission from the rights-holder(s) directly, unless additional rights are indicated by a Creative Commons license in the record and/ or on the work itself. This Thesis has been accepted for inclusion in WVU Graduate Theses, Dissertations, and Problem Reports collection by an authorized administrator of The Research Repository @ WVU. For more information, please contact researchrepository@mail.wvu.edu. 


\title{
Numerical Modeling of Chemical Recovery from Black Liquor Char
}

\author{
Dharmarajan Hariharan
}

Thesis submitted to the College of Engineering and Mineral Resources at West Virginia University in partial fulfillment of the requirements for the Degree of

\author{
Master of Science \\ in \\ Chemical Engineering
}
Aubrey L. Miller. Ph.D., Chair Eung H. Cho, Ph.D. Charter D. Stinespring, Ph.D. Edward J. Boyle Ph.D.

Department of Chemical Engineering

\section{Morgantown, West Virginia. 2001.}

Keywords: Black Liquor, Chemical Recovery, Char Combustion, Modeling and Simulation. Copyright 2001 Dharmarajan Hariharan. 


\section{ABSTRACT \\ Numerical Modeling of Chemical Recovery from Black Liquor Char \\ Dharmarajan Hariharan}

A complete CFD model for the char burning stage of chemical recovery from black liquor is presented. Chemical recovery from black liquor is characterized by the occurrence of multiple, simultaneous reactions occurring in dynamic flow conditions. Rate equations for the different chemical reactions are incorporated into a multiphase CFD code MFIX. Rate equations for sulfate reduction by carbon, gasification of carbon by $\mathrm{CO}_{2}$ and $\mathrm{H}_{2} \mathrm{O}$, and, $\mathrm{COS}$ and $\mathrm{H}_{2} \mathrm{~S}$ formation, are incorporated into MFIX, to simulate the chemical kinetics occurring in the char burning stage. Oxidation of carbon and $\mathrm{Na}_{2} \mathrm{~S}_{\text {by }} \mathrm{O}_{2}$ are also included.

Pyrolysis of black liquor char in the presence of $\mathrm{N}_{2}$, gasification in the presence of $\mathrm{CO}_{2}$ and $\mathrm{H}_{2} \mathrm{O}$ were simulated. Results for pyrolysis and gasification, and variation with respect to temperature are presented. Two different models for sulfate reduction are compared with each other and with published experimental results. Competitive consumption of carbon by sodium sulfate and gasification reactions is studied and the effects of temperature, and heating rates of solids are discussed. 


\section{ACKNOWLEDGEMENTS}

The author would like to express his sincere gratitude to his advisor, Dr. Aubrey L. Miller, for his ideas, advice, and continued guidance throughout this investigation. Also acknowledged are the contributions made by the members of his academic examining committee: Dr. Edward J. Boyle, Dr. Charter D. Stinespring and Dr. Eung H. Cho.

The author is also thankful for all the assistance received from Dr. Madhava Syamlal and Dr. Chris Guenther, of National Energy Technology Laboratories, Morgantown, for their patient answers to all the queries posed to them, regarding the simulation software MFIX.

Mr. Neeraj N. Pugalia is especially thanked for all his thoughts and assistance in the various discussions the author had with him. 


\section{TABLE OF CONTENTS}

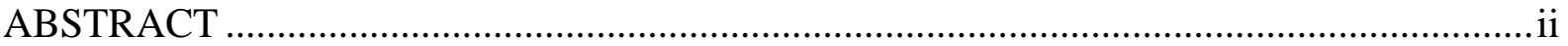

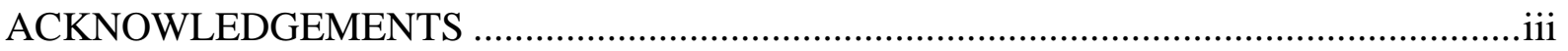

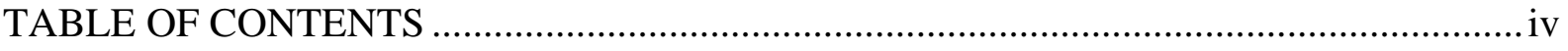

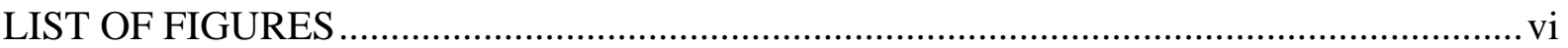

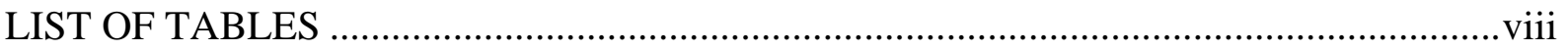

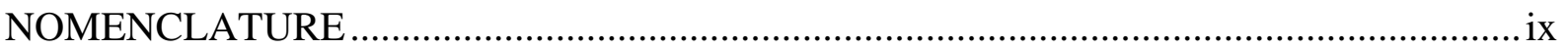

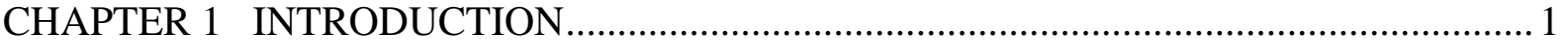

1.1 Introduction to Kraft Pulping Process ...................................................................... 1

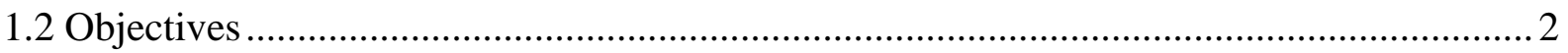

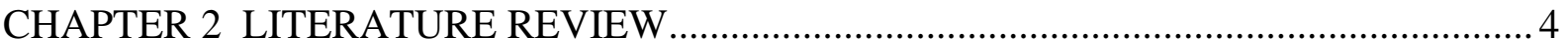

2.1 Introduction to Black Liquor Chemical Recovery .................................................... 4

2.2 Stages During Black Liquor Chemical Recovery ...................................................... 5

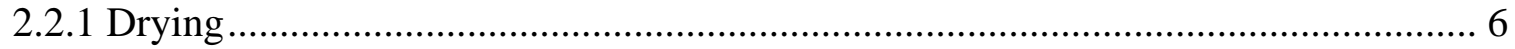

2.2.2 Devolatilization ..................................................................................... 7

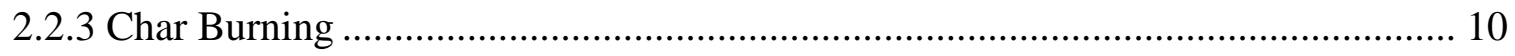

2.2.4 Models for Black Liquor Char Burning ............................................................. 14

CHAPTER 3 NUMERICAL SIMULATION …......................................................... 21

3.1 Kinetic Models for Black Liquor Chemical Recovery ............................................. 21

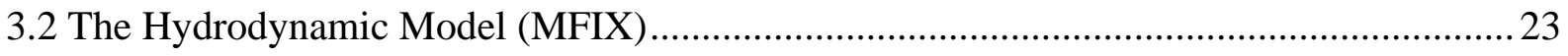

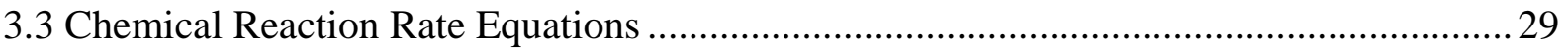

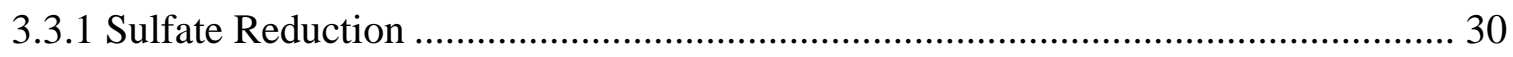

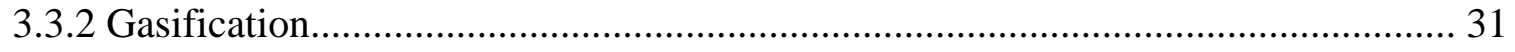

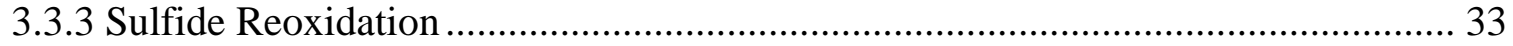

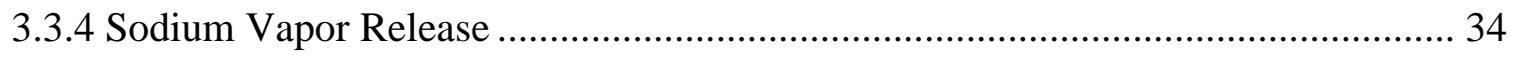

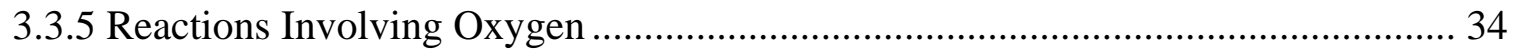

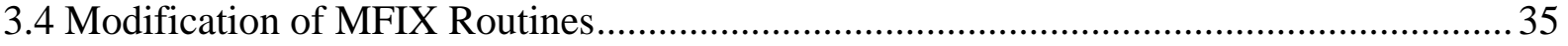

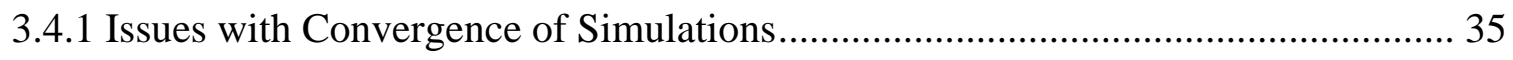

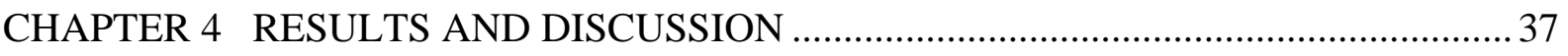

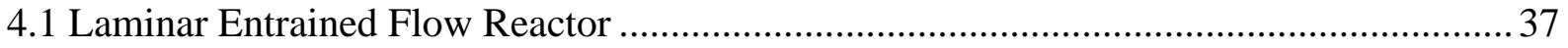




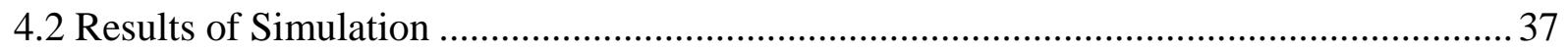

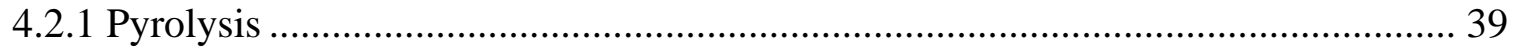

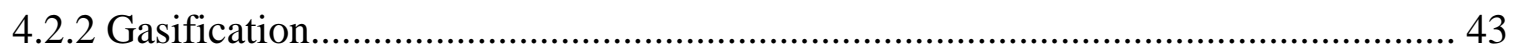

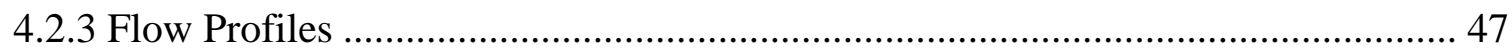

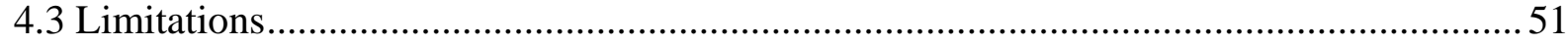

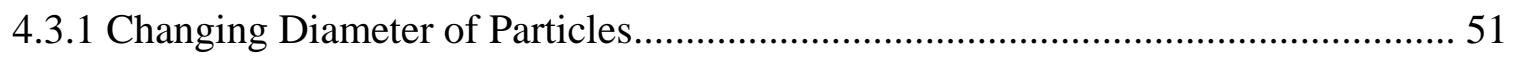

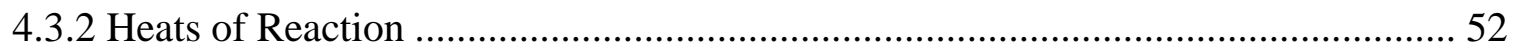

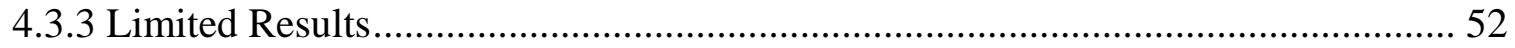

4.4 Extending the Model and Future Work ............................................................... 53

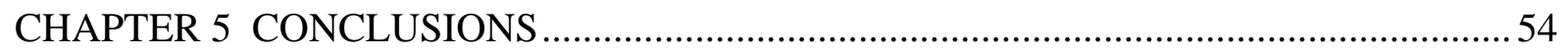

APPENDIX A Diffusion and Mass Transfer Coefficients.............................................. 55

APPENDIX B Equilibrium/Film Concentrations of Gas Species.....................................57

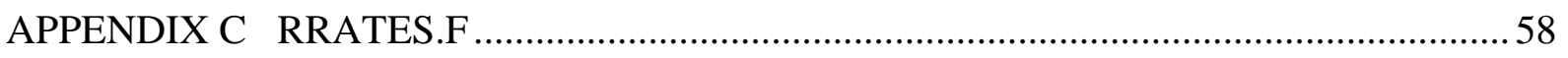

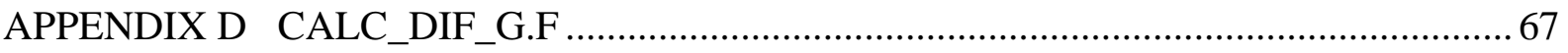

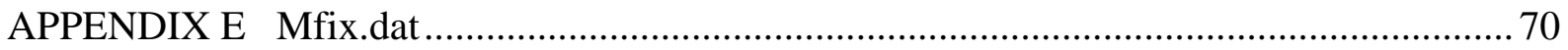

APPENDIX F Heat Capacities and Heats of Formation ............................................. 75

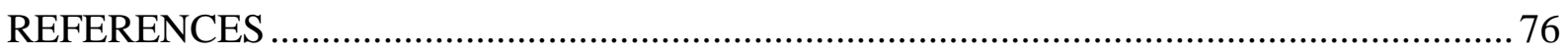




\section{LIST OF FIGURES}

Figure 2-1. Schematic diagram of the Kraft process of paper manufacture...........................5

Figure 2-2. Schematic diagram of a recovery furnace. .................................................. 6

Figure 2-3. Stages in black liquor droplet burning ..................................................... 13

Figure 2-4. Diameter changes during burning of kraft liquor in air at $800^{\circ} \mathrm{C} \ldots \ldots \ldots \ldots \ldots \ldots \ldots . . . . . . . . . .13$

Figure 2-5. Temperature changes during burning of kraft liquor in air at $800^{\circ} \mathrm{C}$................ 14

Figure 2-6. Effect of temperature on times for drying, devolatilization and char burning. .... 14

Figure 2-7. Comparison of model and experimental data by Kymäläinen et al.................... 19

Figure 2-8. Comparison of model and experimental data by Wåg et al............................. 20

Figure 2-9. Modeling results from Wåg et al. ............................................................. 20

Figure 4-1. The laminar entrained flow reactor and experimental conditions. ...................... 38

Figure 4-2a. Sulfate flow during pyrolysis of black liquor char (C-G Eqn.). ...................... 40

Figure 4-2b. Sulfide flow during pyrolysis of black liquor char (C-G Eqn.)......................40

Figure 4-2c. Carbon flow during pyrolysis of black liquor char. (C-G eqn. for sulfate

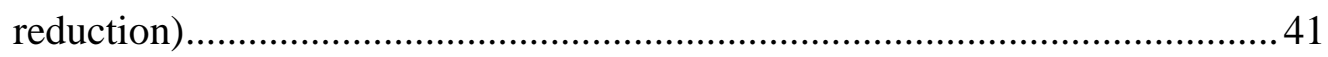

Figure 4-3a. Sulfate flow during pyrolysis of black liquor char (Wåg Eqn.)....................... 42

Figure 4-3b. Sulfide flow during pyrolysis of black liquor char (Wåg Eqn.) ....................... 42

Figure 4-3c. Carbon flow during pyrolysis of black liquor char. (Wåg Eqn. for sulfate

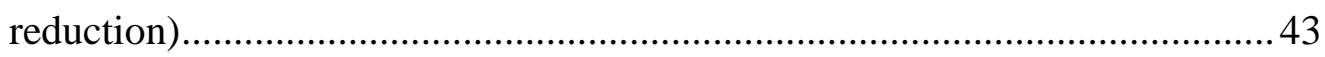

Figure 4-4a. Sulfate flow during gasification of black liquor char at $900-1100^{\circ} \mathrm{C}$. (C-G

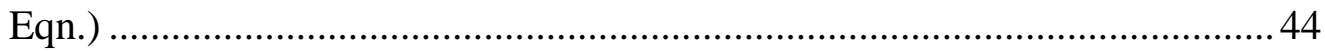

Figure 4-4b. Sulfide flow during gasification of black liquor char at $900-1100^{\circ} \mathrm{C}$. (C-G

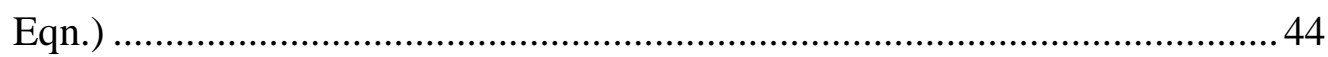

Figure 4-4c. Carbon flow during gasification of black liquor char at $900-1100^{\circ} \mathrm{C}$. (C-G

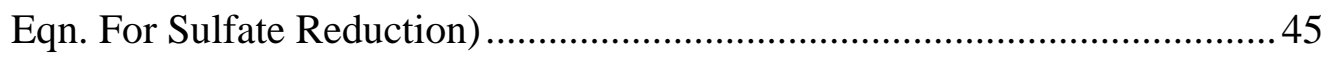

Figure 4-5a. Sulfate flow during gasification of black liquor char at 900-1100 C. (Wåg

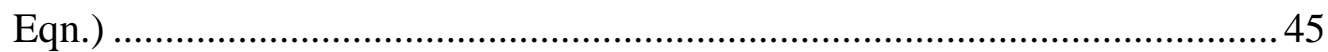

Figure 4-5b. Sulfide flow during gasification of black liquor char at $900-1100^{\circ} \mathrm{C}$. (Wåg

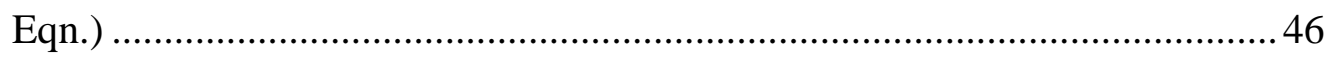


Figure 4-5c. Carbon flow during gasification of black liquor char at $900-1100^{\circ} \mathrm{C}$. (Wåg Eqn. for sulfate reduction) ............................................................. 46

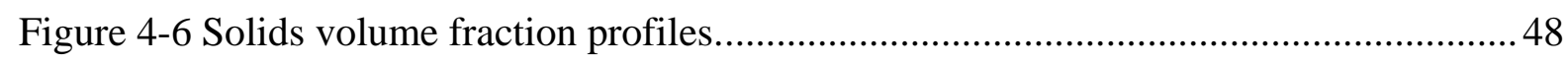

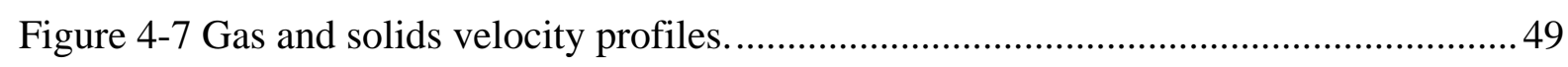

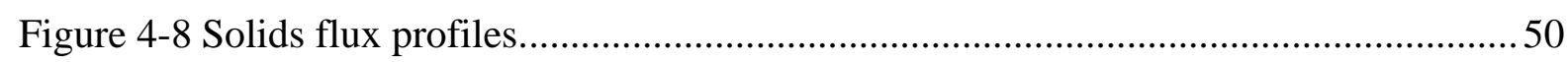

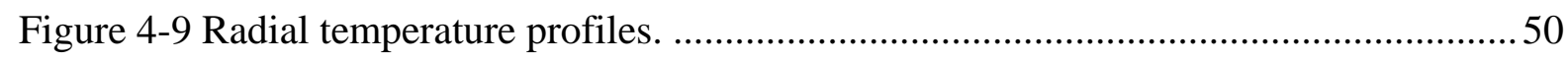

Figure 4-10 Axial temperature profiles. ................................................................... 51 


\section{LIST OF TABLES}

Table 2-1. Complete List of Reactions in the Char Burning Stage..................................... 11

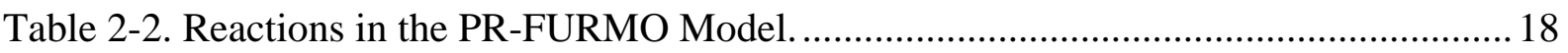

Table 3-1. Sample Composition of Dried Black Liquor Char Particles................................. 22

Table 3-2. Sample Composition of Feed Gas................................................................. 22

Table 3-3. List of Reactions Added to MFIX Routines. ..................................................... 30

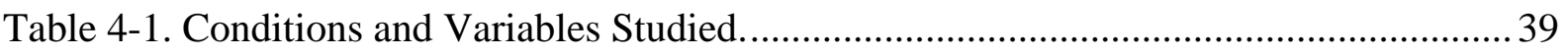

Table A-1. Constants for Shomate Equation................................................................ 75 


\section{NOMENCLATURE}

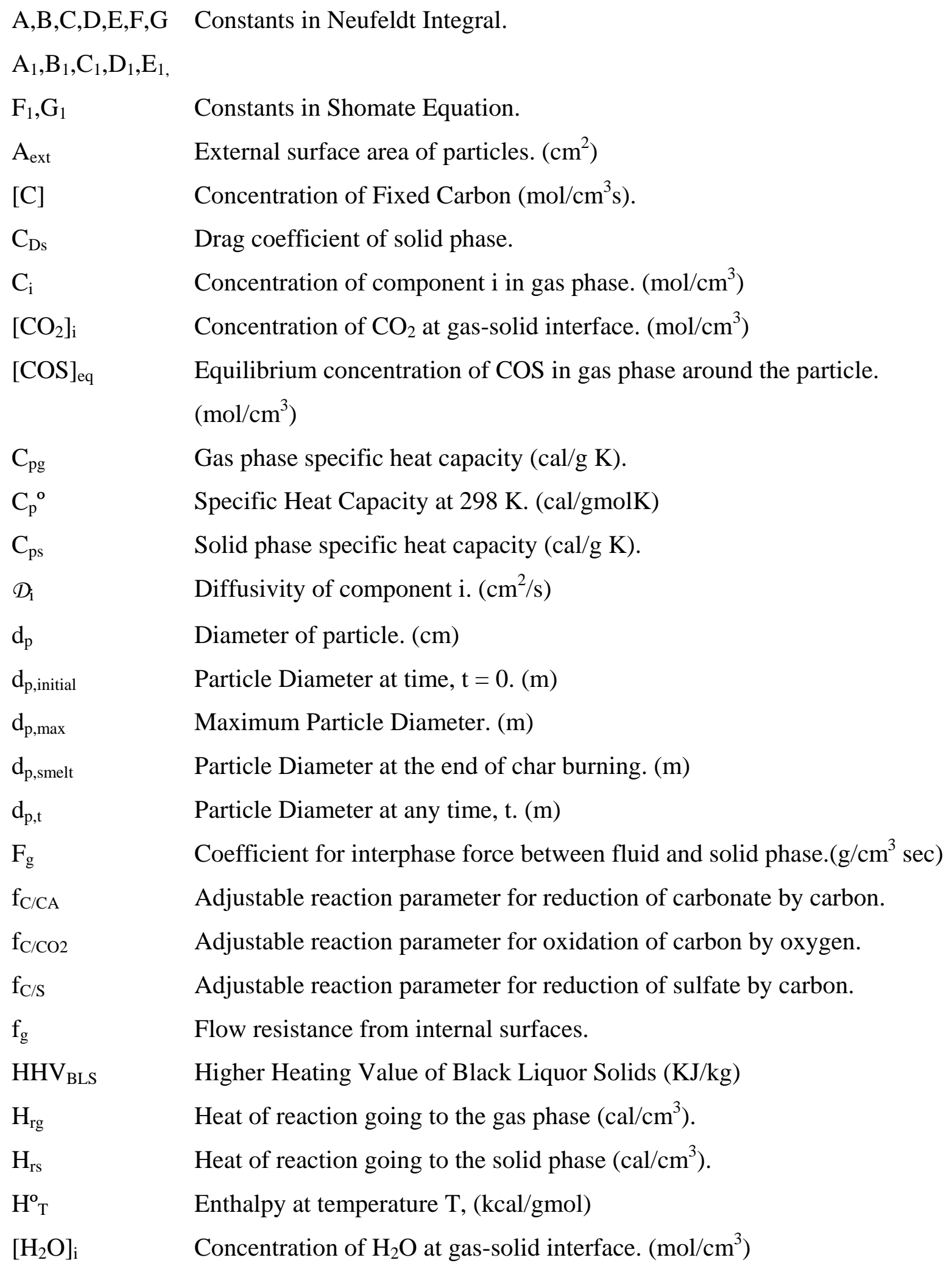




\begin{tabular}{|c|c|}
\hline$\left[\mathrm{H}_{2} \mathrm{~S}\right]_{\mathrm{eq}}$ & Equilibrium concentration of $\mathrm{H}_{2} \mathrm{~S} .\left(\mathrm{mol} / \mathrm{cm}^{3}\right)$ \\
\hline $\mathrm{I}_{\mathrm{g}}$ & Momentum transfer between solid phase and the gas phase. \\
\hline $\mathrm{k}$ & Boltzman's constant. \\
\hline $\mathrm{kg}_{\mathrm{i}}$ & Mass transfer coefficient of component $i$ in gas phase. $(\mathrm{cm} / \mathrm{s})$ \\
\hline $\mathrm{k}_{\mathrm{ri}}$ & Apparent first order reaction constant for component $\mathrm{i}$. \\
\hline $\mathrm{L}$ & Length (cm) \\
\hline $\mathrm{M}_{\mathrm{A}}, \mathrm{M}_{\mathrm{B}}$ & Molecular weight of A, B. (g/mol) \\
\hline $\mathrm{M}_{\mathrm{AB}}$ & Mean molecular weight of A and B. \\
\hline $\mathrm{M}_{\text {carbon }}$ & Mass of carbon left in the particle at time, $\mathrm{t} . \mathrm{g}$ ) \\
\hline $\mathrm{M}_{\text {carbon,total }}$ & Mass of carbon in the particle at time, $\mathrm{t}=0 .(\mathrm{g})$ \\
\hline $\mathrm{M}_{\mathrm{ti}}$ & Thiele modulus for component $\mathrm{i}$. \\
\hline $\mathrm{MW}_{\mathrm{g}}$ & Molecular weight of Gas. \\
\hline$\left[\mathrm{Na}_{2} \mathrm{CO}_{3}\right]$ & Concentration of $\mathrm{Na}_{2} \mathrm{CO}_{3} \cdot\left(\mathrm{mol} / \mathrm{cm}^{3}\right)$ \\
\hline$\left[\mathrm{Na}_{2} \mathrm{~S}\right]$ & Concentration of $\mathrm{Na}_{2} \mathrm{~S} .\left(\mathrm{mol} / \mathrm{cm}^{3}\right)$ \\
\hline $\mathrm{N}_{\mathrm{SCI}}$ & Schmidt Number of species $i$ in gas phase. \\
\hline $\mathrm{N}_{\mathrm{SHI}}$ & Sherwood Number of species $i$ in gas phase. \\
\hline $\mathrm{Nu}$ & Solid phase Nusselt number. \\
\hline $\mathrm{P}$ & Pressure (dynes $\left./ \mathrm{cm}^{2}\right)$ \\
\hline $\mathrm{P}_{\mathrm{g}}$ & Pressure $\left(\right.$ dynes $\left./ \mathrm{cm}^{2}\right)$ \\
\hline $\mathrm{P}_{\mathrm{i}}$ & Partial pressure of component $\mathrm{i}$ in gas phase. $\left(\right.$ dynes $/ \mathrm{cm}^{2}$ ) \\
\hline $\mathrm{q}_{\mathrm{g}}$ & Conductive heat flux in gas phase. \\
\hline $\mathrm{q}_{\mathrm{s}}$ & Conductive heat flux in the solid phase. \\
\hline $\mathrm{Q}_{\mathrm{t}}$ & Heat consumed until time, t. $(\mathrm{J})$ \\
\hline $\mathrm{Q}_{\text {Total }}$ & Total heat required. (J) \\
\hline $\mathrm{R}$ & Universal gas constant. \\
\hline $\mathrm{R}_{0}$ & Mass transferred between gas and solid phase. \\
\hline $\mathrm{r}_{\mathrm{C}, \mathrm{CO} 2}$ & Rate of gasification of carbon by $\mathrm{CO}_{2}\left(\mathrm{~mol} / \mathrm{cm}^{3} \mathrm{~s}\right)$. \\
\hline $\mathrm{r}_{\mathrm{C}, \mathrm{H} 2 \mathrm{O}}$ & Rate of gasification of carbon by water vapor $\left(\mathrm{mol} / \mathrm{cm}^{3} \mathrm{~s}\right)$. \\
\hline $\mathrm{R}_{\mathrm{ci}}$ & Reaction rate due to chemical kinetics $\left(\mathrm{mol} / \mathrm{cm}^{3} \mathrm{~s}\right)$. \\
\hline $\mathrm{r}_{\mathrm{COS}}$ & Rate of generation of carbonyl sulfide. $\left(\mathrm{mol} / \mathrm{cm}^{3} \mathrm{~s}\right)$ \\
\hline $\operatorname{Re}$ & Particle Reynolds number. \\
\hline
\end{tabular}




\begin{tabular}{|c|c|}
\hline $\mathrm{R}_{\mathrm{gn}}$ & Rate of production of $\mathrm{n}^{\text {th }}$ chemical species in the fluid phase. $\left(\mathrm{g} / \mathrm{cm}^{3} \mathrm{sec}\right)$ \\
\hline$r_{\mathrm{H} 2 \mathrm{~S}}$ & Rate of generation of hydrogen sulfide. $\left(\mathrm{mol} / \mathrm{cm}^{3} \mathrm{~s}\right)$ \\
\hline $\mathrm{R}_{\mathrm{i}}$ & Total reaction rate $\left(\mathrm{mol} / \mathrm{cm}^{3} \mathrm{~s}\right)$. \\
\hline $\mathrm{R}_{\mathrm{mi}}$ & Rate of mass transfer to the particle $\left(\mathrm{mol} / \mathrm{cm}^{2} \mathrm{~s}\right)$. \\
\hline $\mathrm{r}_{\mathrm{Na} 2 \mathrm{CO} 3}$ & Rate of consumption of $\mathrm{Na}_{2} \mathrm{CO}_{3} \cdot\left(\mathrm{mol} / \mathrm{cm}^{3} \mathrm{~s}\right)$ \\
\hline $\mathrm{R}_{\mathrm{sn}}$ & Rate of production of $\mathrm{n}^{\text {th }}$ chemical species in the solid phase. $\left(\mathrm{g} / \mathrm{cm}^{3} \mathrm{sec}\right)$ \\
\hline $\mathrm{r}_{\mathrm{SO} 4}$ & Rate of consumption of sodium sulfate by carbon $\left(\mathrm{mol} / \mathrm{cm}^{3} \mathrm{~s}\right)$. \\
\hline$\overline{\bar{S}}_{g}$ & Fluid phase stress tensor. $(\mathrm{Pa})$ \\
\hline$\left[\mathrm{SO}_{4}\right]$ & Concentration of Sodium Sulfate $\left(\mathrm{mol} / \mathrm{cm}^{3} \mathrm{~s}\right)$. \\
\hline$\left[\mathrm{SO}_{4}\right]_{1}$ & Ratio of Sodium Sulfate to total Sodium. ( $\left.\mathrm{mol} \mathrm{Na}_{2} \mathrm{SO}_{4} / \mathrm{mol} \mathrm{Na}_{2}\right)$ \\
\hline$\overline{\bar{S}}_{\mathrm{s}}$ & Solid phase stress tensor. $(\mathrm{Pa})$ \\
\hline $\mathrm{t}$ & Reduced temperature $(\mathrm{T} / 1000) \mathrm{K}$ \\
\hline $\mathrm{T}_{\mathrm{c}}$ & Critical temperature. $\mathrm{K}$ \\
\hline $\mathrm{T}_{\mathrm{g}}$ & Gas Temperature $(\mathrm{K})$. \\
\hline $\mathrm{T}_{\mathrm{s}}$ & Temperature of the solid phase. $(\mathrm{K})$ \\
\hline$V_{\text {avg }}$ & Average Velocity $(\mathrm{cm} / \mathrm{s})$ \\
\hline $\mathrm{V}_{\mathrm{c}}$ & Critical Volume $\left(\mathrm{cm}^{3}\right)$ \\
\hline $\mathrm{V}_{\mathrm{g}}$ & Gas phase velocity vector. \\
\hline $\mathrm{Vp}$ & Volume of particle. $\left(\mathrm{cm}^{3}\right)$ \\
\hline $\mathrm{V}_{\mathrm{r}}$ & Terminal settling velocity in a multiparticle system. \\
\hline $\mathrm{V}_{\mathrm{s}}$ & Solid phase velocity vector. \\
\hline $\mathrm{X}_{\mathrm{gn}}$ & Mass fraction of $\mathrm{n}^{\text {th }}$ chemical species in the fluid phase \\
\hline Xs & Conversion sodium sulfide. \\
\hline $\mathrm{X}_{\mathrm{sn}}$ & Mass fraction of $\mathrm{n}^{\text {th }}$ chemical species in the $\mathrm{m}^{\text {th }}$ solid phase \\
\hline$\alpha_{c s}$ & Fraction of black liquor solids remaining as char. \\
\hline$\alpha_{\text {io }}$ & Fraction of black liquor solids remaining as inorganics. \\
\hline$\alpha_{\mathrm{vl}}$ & Fraction of black liquor solids volatilized. \\
\hline$\Delta \mathrm{H}_{\mathrm{f}}^{\mathrm{o}}$ & Standard Heat of Formation. (kcal/mol) \\
\hline$\Delta \mathrm{H}_{\mathrm{rxn}}$ & Heat of Reaction (cal/gmol) \\
\hline$\varepsilon_{\mathrm{g}}$ & Gas volume fraction. \\
\hline
\end{tabular}




$\begin{array}{ll}\varepsilon_{\mathrm{s}} & \text { Volume fraction of } \mathrm{m}^{\text {th }} \text { solid phase. } \\ \gamma_{\mathrm{g}} & \text { Heat transfer coefficient }\left(\mathrm{W} / \mathrm{m}^{2} \mathrm{~K}\right) . \\ \eta_{\mathrm{i}} & \text { Effectiveness factor. } \\ v & \text { Kinematic viscosity. }\left(\mathrm{cm}^{2} / \mathrm{s}\right) \\ \rho^{\prime} & \text { Macroscopic density of the gas phase. } \\ \rho^{\prime}{ }_{\mathrm{s}} & \text { Macroscopic density of the solid phase. } \\ \rho_{\mathrm{g}} & \text { Material density of the gas phase. } \\ \rho_{\mathrm{s}} & \text { Material density of the solid phase. } \\ \sigma_{\mathrm{A}} & \text { Characteristic length. Angstroms. } \\ \tau & \text { Residence time (s) } \\ \Omega_{\mathrm{D}} & \text { Collision integral. }\end{array}$




\section{CHAPTER 1}

\section{INTRODUCTION}

\subsection{Introduction to Kraft Pulping Process}

Kraft pulping process is one of the most widely used processes in the manufacture of paper. Chemical recovery units are an integral part of this process. Not only do they contribute to recycle and reuse of chemicals, they are also critical in optimizing energy consumption. The energy generated from recovery boilers is very significant in quantity, contributing nearly $40 \%$ of the total energy use in pulp industry [2].

The Kraft process has been in use for more than half a century, but research and development continues to enhance the efficiency of chemical and energy recovery and make the process environmentally safe.

Black liquor is the residue from chemical treatment of wood to extract fiber for papermaking. It is a mixture of water, organic matter, and inorganic compounds. Black liquor has emerged as an important fuel. It is reputed to be the sixth most important fuel in the world and "is the largest single volume organic product manufactured by industry apart from agricultural products" [2].

Chemicals and energy are obtained from the black liquor by combustion in a recovery boiler where it undergoes thermal decomposition, and subsequent gasification. The main objective of this recovery process is to recycle the chemicals used for pulping of wood fiber and to generate steam and power from the residual matter. Black liquor droplets burn in four contiguous stages; drying, devolatilization, char burning and smelt coalescence.

While the first stage is characterized by evaporation of water from the liquor droplets, transforming it into particles, the second and subsequent stages involve multiple and 
simultaneous chemical reactions. Drying and devolatilization are characterized by an increase in the size of the particle, while during the char burning stage the particle shrinks leaving only the inorganic constituents in a molten form.

\subsection{Objectives}

The objectives of this research project are to study the chemical recovery processes in Kraft pulping process with the use of numerical simulation and to test and develop models to approximate both the fluid dynamics and reaction kinetics in a recovery reactor. These objectives are realized by simulation of dilute flow reactors (as used by Wåg et al. [8]) to test the kinetics. The software code, "Multiphase Flow with Interphase Exchanges" (henceforth MFIX) is especially suited for such flow conditions.

Thus, the objectives may be summarized as,

- This research aims to be of significance in modeling complete, industrial scale reactors, to benefit the design and operation of recovery boilers.

- Incorporating published rate equations, for the chemical reactions during black liquor chemical recovery, into MFIX, to develop a complete model, which involves both three-dimensional, multiphase hydrodynamics and reaction kinetics.

- Testing the models for the flow conditions published in literature.

- Combine elements from literature and produce an integrated model, unifying the empirical and semi-empirical equations already published.

- Study the flow and reaction behaviors during chemical recovery along dimensions of space and that of time, thus obtaining a reasonably complete description of the many processes. 
- Improving the model behavior and predictability through sensitivity analysis and finding critical parameters affecting the progress.

Chapter 2 of this document provides an introduction to the literature regarding black liquor chemical recovery and the various models found in literature. Chapter 3 details the hydrodynamic model (MFIX), the model for kinetics and the conditions for which results are reported in this thesis. The results are presented in Chapter 4, followed by a discussion and the Appendices. 


\section{CHAPTER 2}

\section{LITERATURE REVIEW}

\subsection{Introduction to Black Liquor Chemical Recovery}

The spent liquor from chemical treatment of wood, in the Kraft pulping process, is known as black liquor. A schematic diagram of the Kraft process for paper manufacture is presented in Figure 2-1. This by-product is subjected to chemical recovery and is also a major source of energy. The liquor, which consists of water, organic matter and inorganic salts, is dilute when fresh from the pulping process. Industrially, starting from "weak liquor", the steps involved in chemical recovery involve evaporating the "weak liquor" in multiple effect evaporators to yield "strong" black liquor, which contains about 50-60\% solids [31]. This "strong black liquor is then sprayed into a furnace through nozzles, as shown in Figure 2-2.

Black liquor droplets go through distinct stages in the chemical recovery furnace. The droplets undergo drying to eliminate remaining moisture. This stage is followed by an intense burning process known as "devolatilization" where most organic matter is burnt away, producing heat. This occurs in the oxidizing section of the furnace, as shown in Figure 2-2. Subsequent to devolatilization, multiple-parallel reactions occur during a stage generally referred to as "char burning" which yields chemicals that are eventually reused to treat wood (reducing section in Figure 2-2.) Air is introduced into the furnace at various points to dry as well as burn away the organic constituents in the black liquor solids. The smelt collected at the bottom, consists of molted inorganic salts, which are further cleaned to recover the chemicals used as pulping agents for wood fiber. While devolatilization is important with 
respect to energy generation, the char burning stage is relevant for chemical recovery from black liquor solids.

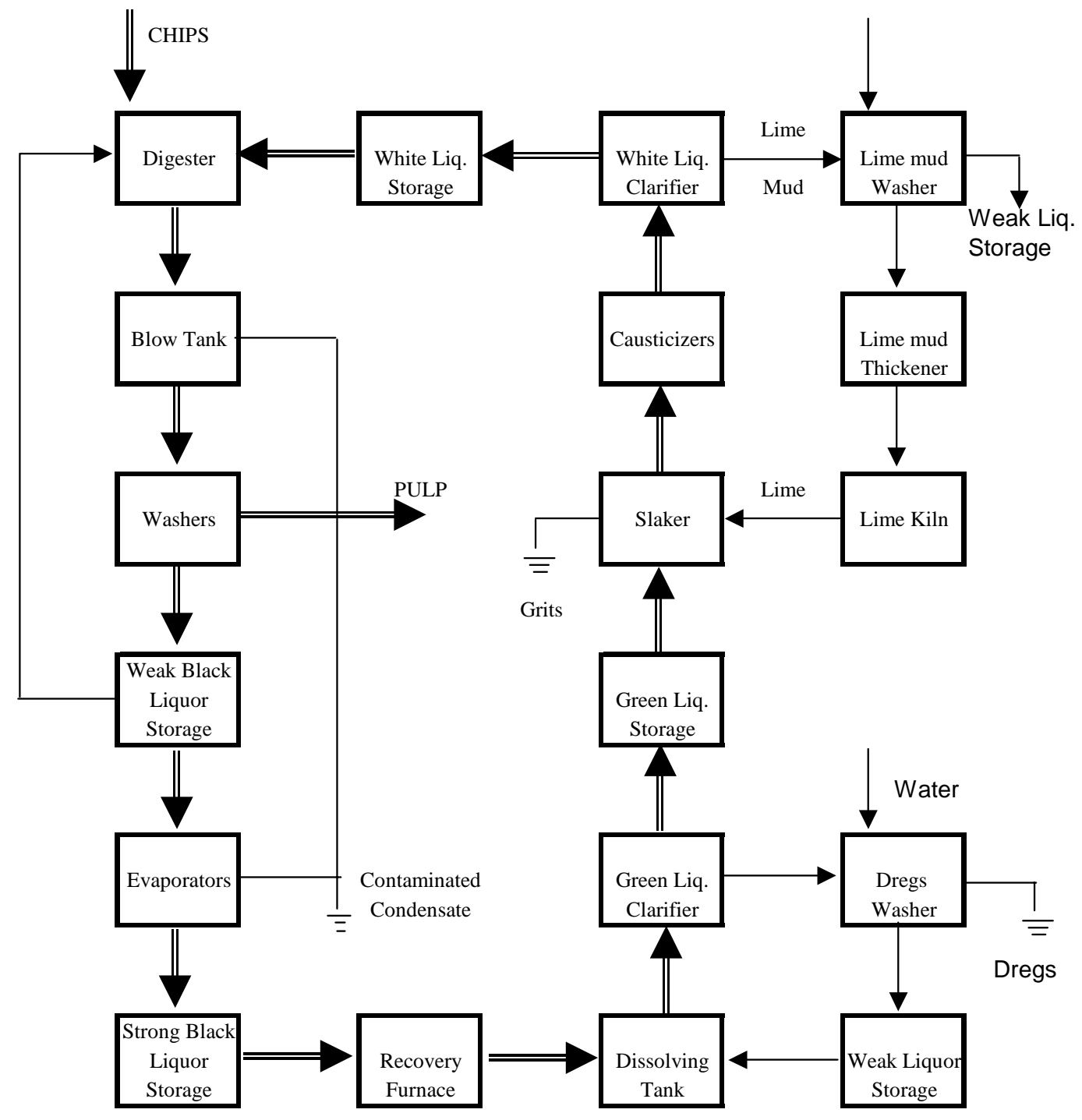

Figure 2-1. Schematic diagram of the Kraft process of paper manufacture.

\subsection{Stages During Black Liquor Chemical Recovery}

Black liquor burns in a manner similar to other carbon based solid fuels. However, black liquor char is several orders of magnitude more reactive than other coal chars due to the presence of alkali salts. The burning of black liquor in recovery furnaces proceeds in four stages, a) drying, b) devolatilization, c) char burning, d) smelt coalescence, as shown in 
Figure 2-3. Smelt coalescence is the final phase where the inorganic salts in the black liquor char particle coalesce due to surface tension effects and the particle falls to the bottom of the furnace, in a semi molten state. This stage is not discussed any further in this document.

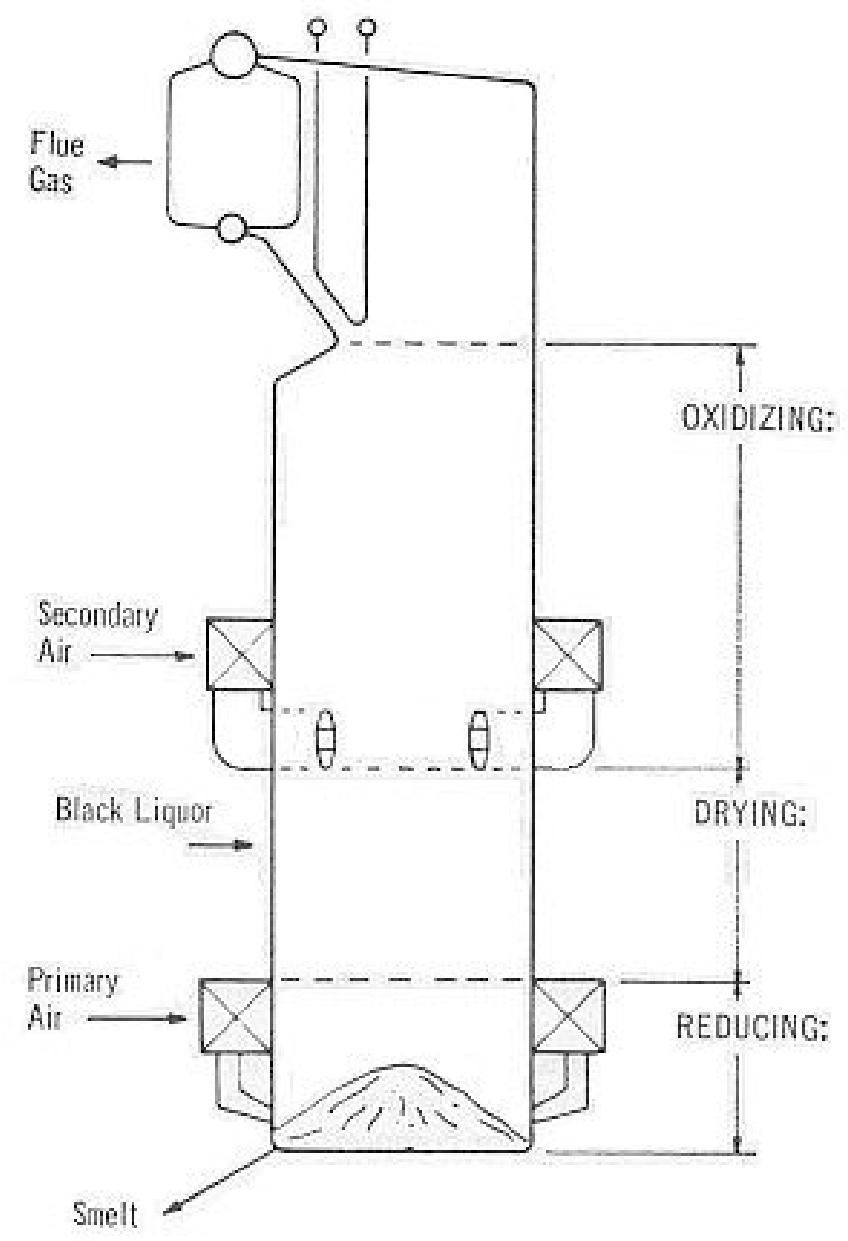

Figure 2-2. Schematic diagram of a recovery furnace.

\subsubsection{Drying}

The drying stage occurs when the black liquor droplet enters the furnace [1]. The moisture content drops from around $60 \%$ to near zero. There is no flame during this stage. The time taken for the particle to begin burning is called "time to ignition".

Drying may well continue into time of ignition, i.e., the particle may continue to dry after it has started to burn. This process is completely controlled by heat transfer. 
Research by Frederick et al. [1] has shown that the droplet may swell by a factor of around 1.5 during drying and this expansion is independent of furnace conditions, temperature, and initial droplet mass. During drying, the particle expands and collapses in rapid succession, expanding its surface area and mixing its contents [1]. This mixing also determines the ability of the particle to absorb heat. An increase in the viscosity of the liquor sprayed into the furnace reduces the swelling and hence the heat-flux to the core of the particle. This leads to a rise in temperature of the surface, which inhibits further heat transfer to the particle. When the black liquor droplets are nearly dry (90-95\% solids), the surface starts to burn while the core is still being dried.

A smaller initial viscosity (lower solids content in the droplets sprayed) has the reverse effect. The effect of increasing viscosity (higher solids content in the sprayed liquor) is twofold, inhibiting heat transfer on one hand while decreasing the amount of moisture that needs to be removed, on the other. A model for drying proposed by Frederick et al. [1] assumes that drying is controlled by heat transfer only.

\subsubsection{Devolatilization}

The process of burning combustible volatiles or loss of combustible mass (upon heating) is called devolatilization. Dried black liquor particles, consisting of organic compounds and inorganic salts burn rapidly. Devolatilization is marked by the appearance of a flame that quickly engulfs the particle. The black liquor particle also swells during this stage, and the flame disappears when the particle reaches its maximum size. This time for which the flame is visible is referred to as the "devolatilization" time [1].

The onset of devolatilization and end of drying are not distinctly separable. This has a bearing on the trajectories of particles and the heat release in recovery boilers. Higher 
temperatures increase the overlap between drying and devolatilization. The organic materials in black liquor degrade thermally (pyrolyze) and release volatiles like $\mathrm{CO}_{2}, \mathrm{CO}, \mathrm{H}_{2} \mathrm{O}, \mathrm{H}_{2}$, light hydrocarbons, tars, $\mathrm{H}_{2} \mathrm{~S}$ etc. The remaining solid materials include residual non-volatile organic compounds and inorganic salts.

The interior temperature of the droplet rises rapidly during devolatilization. This is illustrated in Figure 2-5, which represents the particle temperature estimation for 1.3mm black liquor droplets with $60 \%$ solids burnt in air, at $800^{\circ} \mathrm{C}$. Frederick et al. [4] report a broad distribution in the times of ignition for different liquors at the same furnace temperature and conclude that this might be due to liquor specific pyrolysis occurring at the onset of devolatilization. The time to ignition has an impact on the stability of operation; with the liquors that take longer to ignite presenting a greater difficult in their burning.

The time of devolatilization is a function of initial droplet size and the amount of oxygen present to burn up the organic matter. Figure 2-6 illustrates the time taken for different stages of the chemical recovery and the variation with the temperature of the furnace. The data are for black liquor droplets of $1.5 \mathrm{~mm}$ diameter and initial solids content of $60 \%$ [29]. Some of the carbonaceous compounds are reduced to elemental carbon due to the lack of oxygen to combust all of the organic compounds. This unconsumed elemental carbon is important for the reduction of alkali sulfates during char burning stage.

Other important features of the process of devolatilization include the change in particle size and the evolution of various species like sulfur compounds and alkali metals or alkali salts. It is known that small bits of the black liquor particles escape as ejecta $(1-30 \mu \mathrm{m})$ and they often contain molten salts of sodium and potassium, which combined with the release of metallic sodium, can be troublesome in the operation of commercial reactors. Lack 
of data is cited as a major reason for the lack of reliable models to accurately predict such and other emissions. Sodium is released during devolatilization by the vaporization of $\mathrm{NaCl}$, ejection of particles from the solids, and through reduction of $\mathrm{Na}_{2} \mathrm{CO}_{3}$ (at higher temperatures, $>800^{\circ} \mathrm{C}$.) The relative importance of these paths is dependent on the temperature of the gases and the particle heating-rate. Larger particles result in greater losses of solids in the form of ejecta [5]. Sulfur release starts with the decomposition of the organic materials in the black liquor solids during devolatilization. The rate of sulfur release is dependent on the chemical kinetics and the heating rate of the particles. Heat transfer is more significant at higher temperatures $\left(>700^{\circ} \mathrm{C}\right)$ and thus is the controlling factor in most reactors [5]. The amount of sulfur released depends on the heating rates of the particles. Experimental results from pyrolysis of black liquor particles, indicate that the amounts were unaffected by temperature between the range $400-1000^{\circ} \mathrm{C}$, at low heating rates $\left(\sim 1^{\circ} \mathrm{C} / \mathrm{s}\right)$ [5]. At higher heating rates $\left(\sim 100^{\circ} \mathrm{C} / \mathrm{s}\right)$, the amount of sulfur released went through a maximum between 400 and $700^{\circ} \mathrm{C}$. Even higher heating rates reduced this temperature for maximum sulfur release [5].

Substantial change in the size of particles is an important feature of black liquor combustion. Frederick et al. [4] model the change in diameter as a function of the heat consumed/formed during devolatilization. They propose an equation of the form indicated below, where, the factor $n_{v}$ is reported to be 0.8 and the $Q_{\text {total }}$ refers to the total heat of devolatilization.

$$
\frac{\mathrm{d}_{\mathrm{p}, \mathrm{t}}-\mathrm{d}_{\mathrm{p}, \text { initial }}}{\mathrm{d}_{\mathrm{pMAX}}-\mathrm{d}_{\mathrm{p} \text {,initial }}}=\left(\frac{\mathrm{Q}_{\mathrm{t}}}{\mathrm{Q}_{\text {Total }}}\right)^{0.8}
$$

Figure 2-4 presents a characteristic picture of the nature of changes in the size of a black liquor particle (for a particle burnt in air at $800^{\circ} \mathrm{C}$.) It can be noted that the drying and 
devolatilization stages are characterized by the increase in the size of the particles and the end of devolatilization is characterized by the maximum diameter reached by the particle.

Modeling devolatilization is a difficult task due to lack of sufficient and precise data, and complex stoichiometry. Hence, the lack of rate equations for the different chemical reactions imposes a limitation on the detail and complexity that can be achieved in numerically modeling this stage. Existing models for devolatilization either aggregate the processes into a general process [18] (also see Table 2-2), or involve simple mass and species balance to calculate the distribution of species and heat of volatilization.

\subsubsection{Char Burning}

The remaining char, after devolatilization, mainly consist of $\mathrm{Na}_{2} \mathrm{CO}_{3}, \mathrm{Na}_{2} \mathrm{SO}_{4}$, carbon and some $\mathrm{Na}_{2} \mathrm{~S}$. An important reaction occurring in the char is the reduction of $\mathrm{Na}_{2} \mathrm{SO}_{4}$ to $\mathrm{Na}_{2} \mathrm{~S}$ which is essential for the recycling of process chemicals. In addition to this reaction, the carbon present is gasified by $\mathrm{CO}_{2}, \mathrm{H}_{2} \mathrm{O}$, and $\mathrm{O}_{2}$ present in the gas phase [1]. Char burning is less complex than devolatilization, but consists of parallel reactions. The particles shrink during char burning, typically by a factor of six in diameter (see Figure 2-4) [1]. The time for char burning is related to the diameter of the solid particle, as char burning is also controlled by mass transfer, in addition to chemical reaction rates. The temperature of a particle may rise well above the furnace temperature, when burnt in the presence of oxygen.

Figure 2-4 shows the change in diameter of a black liquor particle being burnt in air [1]. Figure 2-5 presents the temperature changes in a particle during the entire process. It can be noted that the maximum volume corresponds to the end of devolatilization and onset of char burning and the temperatures reaches a maximum during char burning. Figure 2-6 shows the times for onset of devolatilization (time of ignition), completion of devolatilization, and 
char burning time, as a function of furnace temperature. The effect of heat transfer in speeding up these processes is evident from Figure 2-6. The list of possible reactions at the char burning stage is presented in Table 2-1 [10].

Char burning involves both oxidation and gasification reactions. Black liquor char is depleted of carbon rapidly due to the reduction of sodium sulfate to sodium sulfide and gasification/combustion of carbon by $\mathrm{CO}_{2}, \mathrm{H}_{2} \mathrm{O}$ and $\mathrm{O}_{2}$. Black liquor char is reported to be more reactive than other coal chars [4]. It is about an order of magnitude more reactive than activated carbon with the same alkali content and is about three times more reactive than activated carbon with no alkali content. Under conditions usually prevalent in reactors (high temperatures), the char burning is predominantly a mass transfer controlled process.

Table 2-1. Complete List of Reactions in the Char Burning Stage.

\begin{tabular}{|c|c|}
\hline 1 & $\mathrm{C}(\mathrm{s})+\mathrm{O}_{2}(\mathrm{~g}) \rightarrow \mathrm{CO}_{2}(\mathrm{~g})$ \\
\hline 2 & $\mathrm{C}(\mathrm{s})+\mathrm{CO}_{2}(\mathrm{~g}) \rightarrow 2 \mathrm{CO}(\mathrm{g})$ \\
\hline 3 & $\mathrm{C}(\mathrm{s})+\mathrm{H}_{2} \mathrm{O}(\mathrm{g}) \rightarrow \mathrm{CO}(\mathrm{g})+\mathrm{H}_{2}(\mathrm{~g})$ \\
\hline 4 & $\mathrm{C}(\mathrm{s})+\mathrm{Na}_{2} \mathrm{CO}_{3}(\mathrm{~s}, \mathrm{l}) \rightarrow 2 \mathrm{Na}(\mathrm{g})+3 \mathrm{CO}(\mathrm{g})$ \\
\hline 5 & $\mathrm{C}(\mathrm{s})+\mathrm{K}_{2} \mathrm{CO}_{3}(\mathrm{~s}, \mathrm{l}) \rightarrow 2 \mathrm{~K}(\mathrm{~g})+3 \mathrm{CO}(\mathrm{g})$ \\
\hline 6 & $2 \mathrm{C}(\mathrm{s})+\mathrm{Na}_{2} \mathrm{SO}_{4}(\mathrm{~s}, \mathrm{l}) \rightarrow \mathrm{Na}_{2} \mathrm{~S}(\mathrm{~s}, \mathrm{l})+2 \mathrm{CO}_{2}(\mathrm{~g})$ \\
\hline 7 & $\mathrm{Na}_{2} \mathrm{~S}(\mathrm{~s}, \mathrm{l})+2 \mathrm{O}_{2}(\mathrm{~g}) \rightarrow \mathrm{Na}_{2} \mathrm{SO}_{4}(\mathrm{~s}, \mathrm{l})$ \\
\hline 8 & $\mathrm{Na}_{2} \mathrm{~S}(\mathrm{~s}, \mathrm{l})+2 \mathrm{CO}_{2}(\mathrm{~g}) \rightarrow \mathrm{Na}_{2} \mathrm{CO}_{3}(\mathrm{~s}, \mathrm{l})+\mathrm{COS}(\mathrm{g})$ \\
\hline 9 & $\mathrm{Na}_{2} \mathrm{~S}(\mathrm{~s}, \mathrm{l})+\mathrm{CO}_{2}(\mathrm{~g})+\mathrm{H}_{2} \mathrm{O}(\mathrm{g}) \rightarrow \mathrm{Na}_{2} \mathrm{CO}_{3}(\mathrm{~s}, \mathrm{l})+\mathrm{H}_{2} \mathrm{~S}(\mathrm{~g})$ \\
\hline 10 & $\mathrm{NaCl}(\mathrm{s}, \mathrm{l}) \leftrightarrow \mathrm{NaCl}(\mathrm{g})$ \\
\hline 11 & $\mathrm{KCl}(\mathrm{s}, 1) \leftrightarrow \mathrm{KCl}(\mathrm{g})$ \\
\hline 12 & $\mathrm{CO}(\mathrm{g})+1 / 2 \mathrm{O}_{2}(\mathrm{~g}) \rightarrow \mathrm{CO}_{2}(\mathrm{~g})$ \\
\hline 13 & $\mathrm{H}_{2}(\mathrm{~s})+1 / 2 \mathrm{O}_{2}(\mathrm{~g}) \rightarrow \mathrm{H}_{2} \mathrm{O}(\mathrm{g})$ \\
\hline 14 & $2 \mathrm{Na}(\mathrm{g})+1 / 2 \mathrm{O}_{2}(\mathrm{~g}) \rightarrow \mathrm{Na}_{2} \mathrm{O}(\mathrm{g})$ \\
\hline 15 & $2 \mathrm{~K}(\mathrm{~g})+1 / 2 \mathrm{O}_{2}(\mathrm{~g}) \rightarrow \mathrm{K}_{2} \mathrm{O}(\mathrm{g})$ \\
\hline 16 & $\mathrm{Na}_{2} \mathrm{O}(\mathrm{g})+\mathrm{CO}_{2}(\mathrm{~g}) \rightarrow \mathrm{Na}_{2} \mathrm{CO}_{3}(\mathrm{~s}, \mathrm{l})$ \\
\hline 17 & $\mathrm{~K}_{2} \mathrm{O}(\mathrm{g})+\mathrm{CO}_{2}(\mathrm{~g}) \rightarrow \mathrm{K}_{2} \mathrm{CO}_{3}(\mathrm{~s}, 1)$ \\
\hline 18 & $2 \mathrm{Na}_{2} \mathrm{O}(\mathrm{g})+2 \mathrm{SO}_{2}(\mathrm{~g})+\mathrm{O}_{2}(\mathrm{~g}) \rightarrow 2 \mathrm{Na}_{2} \mathrm{SO}_{4}(\mathrm{~s}, \mathrm{l})$ \\
\hline 19 & $2 \mathrm{~K}_{2} \mathrm{O}(\mathrm{g})+2 \mathrm{SO}_{2}(\mathrm{~g})+\mathrm{O}_{2}(\mathrm{~g}) \rightarrow 2 \mathrm{~K}_{2} \mathrm{SO}_{4}(\mathrm{~s}, \mathrm{l})$ \\
\hline
\end{tabular}


At high temperatures $\left(>1100^{\circ} \mathrm{C}\right)$ the chemical reactions are rapid and occur mostly at the surface of the particle [1]. Since the transition temperature (for the transition from chemical reaction controlled regime to mass transfer controlled regime) for the carbon consumption by oxygen or $\mathrm{CO}_{2}$ is higher than that for the sulfate-sulfide cycle (reduction of $\mathrm{Na}_{2} \mathrm{SO}_{4}$ to $\mathrm{Na}_{2} \mathrm{~S}$ by carbon and oxidation of $\mathrm{Na}_{2} \mathrm{~S}$ by $\mathrm{O}_{2}$ ), the gasification/combustion of carbon occurs throughout the particle. However, with higher temperatures $\left(\sim 1100{ }^{\circ} \mathrm{C}\right)$, internal diffusion becomes a limiting factor and more of the gasification/combustion of carbon occurs at the surface [1].

As seen from Figure 2-4, the size of the particle decreases during char burning stage. An empirical equation developed by Frederick et al. [1] relates the change in diameter to carbon consumption, as shown below [29].

$$
\frac{\mathrm{d}_{\mathrm{p}, \mathrm{t}}^{3}-\mathrm{d}_{\mathrm{p}, \mathrm{MAX}}^{3}}{\mathrm{~d}_{\mathrm{p}, \text { MAX }}^{3}-\mathrm{d}_{\mathrm{p}, \text { smelt }}^{3}}=\left(1-\frac{\mathrm{M}_{\text {carbon }}}{\mathrm{M}_{\text {carbon,Total }}}\right)
$$

Some amount of sodium release also takes place during this stage. Sodium release during char burning is relatively less significant compared to sodium release during devolatilization. The primary method for sodium release is through the reduction of sodium carbonate by elemental carbon and this reaction occurs at temperatures above $800^{\circ} \mathrm{C}$. Presence of $\mathrm{CO}$ and $\mathrm{CO}_{2}$ inhibits the sodium vapor release at lower temperatures.

Release of sulfur primarily occurs due to the reaction of $\mathrm{Na}_{2} \mathrm{~S}$ with $\mathrm{CO}_{2}$ and $\mathrm{H}_{2} \mathrm{O}$, forming $\mathrm{H}_{2} \mathrm{~S}$ and COS. The rate of formation of these species is strongly affected by chemical equilibrium. Formation of $\mathrm{COS}$ and $\mathrm{H}_{2} \mathrm{~S}$ is higher at lower temperatures than at higher temperatures. 
Drying

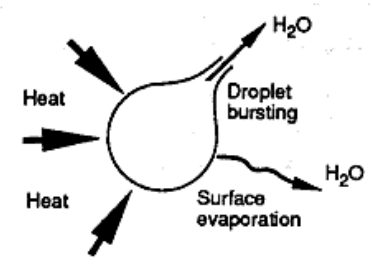

Char Burning

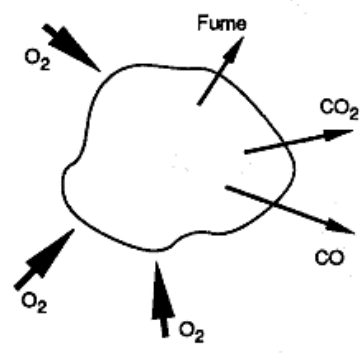

Devolatilization

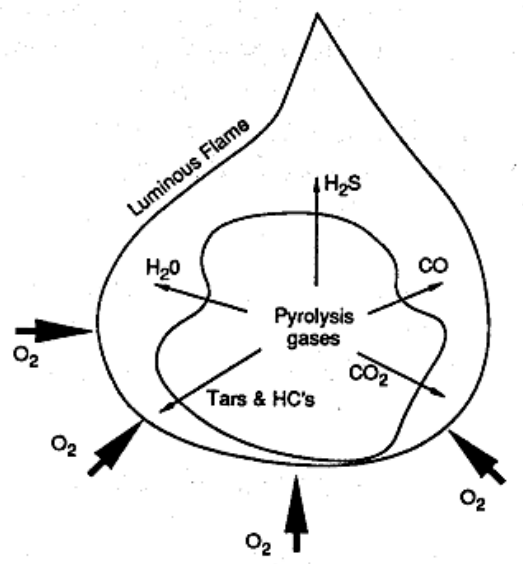

Smelt Coalescence

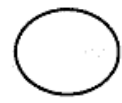

Figure 2-3. Stages in black liquor droplet burning.

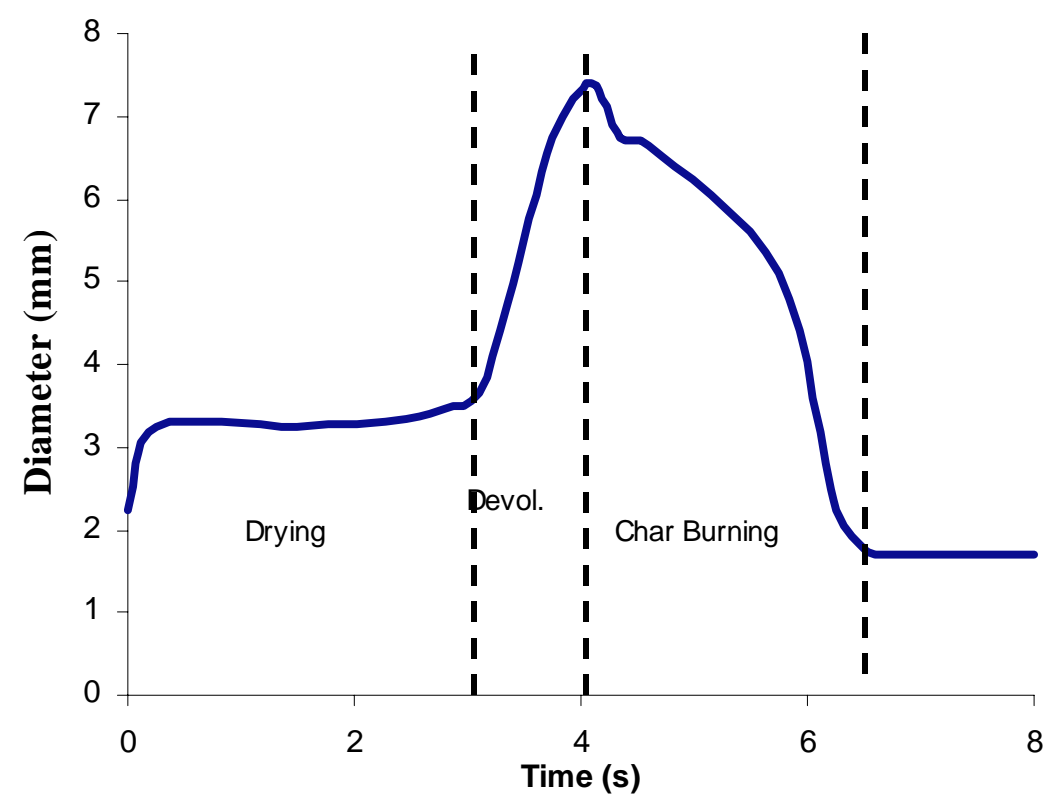

Figure 2-4. Diameter changes during burning of kraft liquor in air at $800^{\circ} \mathrm{C}$. 


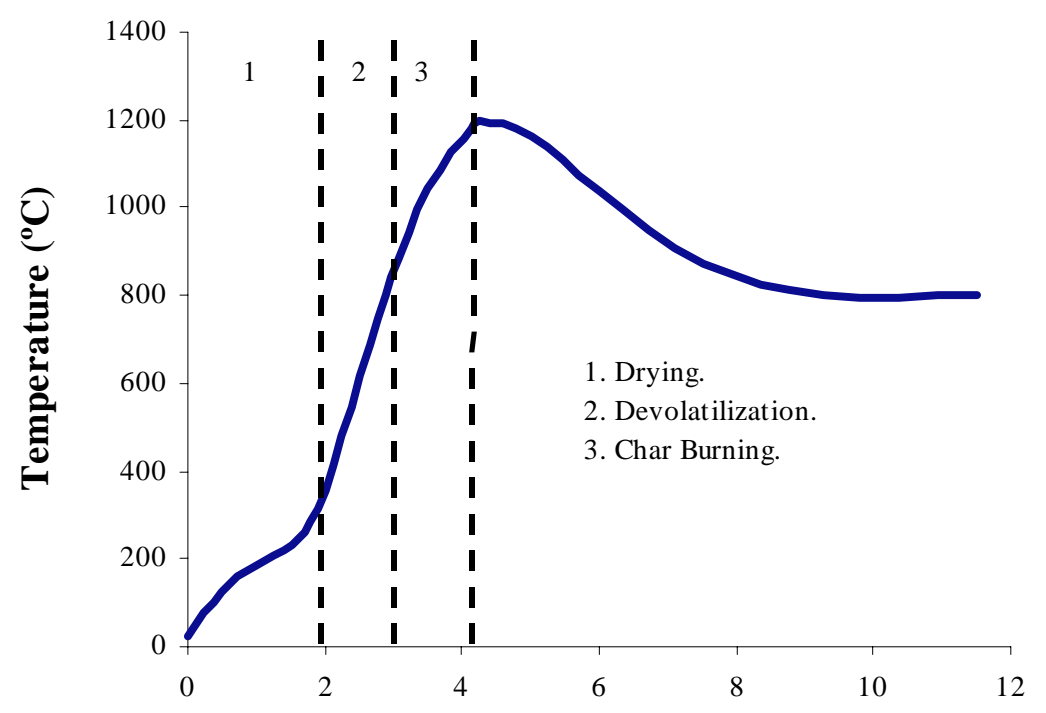

Time (s)

Figure 2-5. Temperature changes during burning of kraft liquor in air at $800^{\circ} \mathrm{C}$.

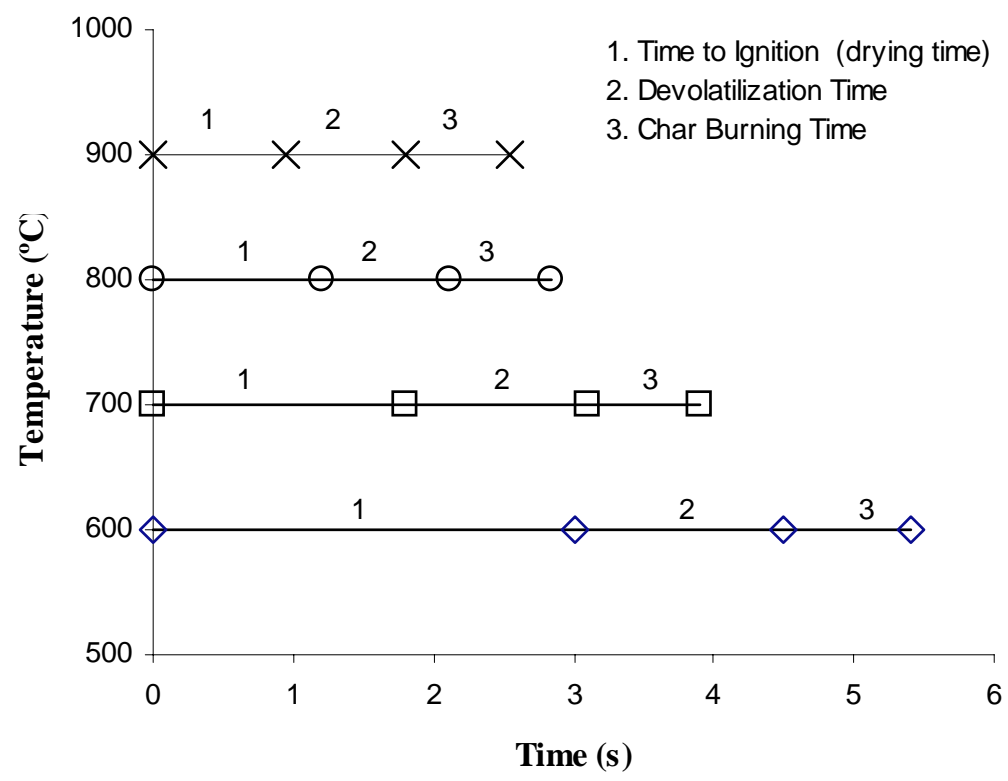

Figure 2-6. Effect of temperature on times for drying, devolatilization and char burning.

\subsubsection{Models for Black Liquor Char Burning}

The main objective of burning the char particles is to convert alkali sulfates to sulfides or carbonates, and convert the carbon to gaseous compounds like $\mathrm{CO}$ and $\mathrm{CO}_{2}$. Since carbon 
is required for reduction of sulfate it is important that the carbon not be gasified too rapidly. The simultaneous occurrence of reduction of sulfates and gasification of carbon make the modeling of the char burning process more complicated than modeling the combustion of coal chars [23].

Reduction of sulfate typically occurs at high temperatures $\left(>800^{\circ} \mathrm{C}\right)$ in a recovery furnace. High temperature, the presence of inorganic salts in molten form, and their corrosive nature, make the study of this reaction difficult. Research by Cameron et al. [23] showed that the reduction of sulfates is accelerated by the presence of gases such as $\mathrm{CO}$ and $\mathrm{CO}_{2}$, which increase the active sites on the surface of carbon in the char particles. They report that the rate of reduction is first order with respect to carbon, and zero order with respect to sulfate at low sulfate concentrations which changes to first order at high sulfate concentrations [23]. Wag et al. [29] report that the rate equation for sulfate reduction proposed by Cameron et al. underpredicts sulfate reduction by an order of magnitude. They proposed an alternative rate equation derived from experimental data for sulfate reduction in black liquor chars.

In addition to the reduction of sulfate to sulfide, carbon is converted to gases such as $\mathrm{CO}$ and $\mathrm{CO}_{2}$ in a recovery furnace. $\mathrm{Li}$ et al. $[11,24]$ report that the gasification of carbon by $\mathrm{CO}_{2}$ and $\mathrm{H}_{2} \mathrm{O}$ is catalyzed by the alkali salts present in the char particle. This catalytic effect is reported to be due to the formation of alkali oxide groups on the carbon surface. They also report significantly higher reactivity of carbon in black liquor char relative to other carbonaceous chars doped with alkali salts, due to the fine dispersion of alkali salts in black liquor char.

Other reactions occurring during black liquor char burning include the oxidation of alkali sulfides to form sulfur bearing gases like COS and $\mathrm{H}_{2} \mathrm{~S}$. Research by Li et al. [26] 
shows that these reactions are limited by the equilibrium concentrations of the product gas species in the film surrounding the particle. The formation of COS was reported to be limited by external mass transfer at low $\mathrm{CO}_{2}$ concentrations and high temperatures $\left(>750^{\circ} \mathrm{C}\right)$, at higher concentrations of $\mathrm{CO}_{2}$ the formation of $\mathrm{COS}$ was a function of conversion of sulfide. The rate of formation of $\mathrm{H}_{2} \mathrm{~S}$ goes through a maximum at $650^{\circ} \mathrm{C}$ and the rate increases with increasing steam concentration for low values of conversion, while the reverse is true for higher values of conversion.

Models for simulating the complete black liquor char burning process are fairly recent. Kinetic models found in literature for black liquor char burning [7,29] involve rate equations for reactions and usually simulate the reactions taking place in a single reactive particle. The models by Frederick et al. [1,4,6,7] and Wag et al. [29] simulate the chemical reactions occurring for a single black liquor char particle, assumed to be falling at its terminal settling velocity in a gas stream of known composition. Such models are very useful in describing the kinetic rate laws and studying the reactions in a char particle. They do not, however, approximate the more complex equations that govern the transport phenomena in recovery furnaces.

Models like PR-FURMO, developed by Verrill et al. [18] seek to model the complete process, while those of Frederick et al. [8] seek to model parts of the process. The PRFURMO model deals with simulation of black liquor chemical recovery in an industrial reactor setup. The list of chemical reactions dealt with, in this model is illustrated in Table 22. This model incorporates all the stages of black liquor chemical recovery. Performance trends were predicted over a range of operating conditions and the authors report that the results demonstrate the utility of the model for a better qualitative understanding of the reactor 
operation [18]. The model was able to provide results in both space and time dimensions, showing variations of species concentrations and other variables.

Work done by Frederick et al. [1,4,6,7,29] also covers all the parts of the process and compared favorably with experimental results. The model, however, consists of a number of sub-models dealing with the various stages. Models dealing with the char burning stage are often complicated due to the parallel reactions. Extensive work in identifying and modeling the reactions in this phase were done by Frederick et al. [10] The model for char burning, based on the work of Frederick et al. involves reactions shown in Table 2-1.

Kymäläinen et al. [7] reported results for gasification and pyrolysis of black liquor char at $1000^{\circ} \mathrm{C}$ using a Laminar Entrained Flow Reactor and compared them to the results obtained from a model for char burning. The model included sulfate reduction equation developed by Cameron and Grace [23], equations for $\mathrm{CO} / \mathrm{CO}_{2}$ gasification of carbon and $\mathrm{H}_{2} \mathrm{~S}$ and COS formation equations developed by Li and Van Heiningen [26].

Comparison of this model with experimental results is presented in Figure 2-7. The results indicated that the Cameron-Grace equation for sulfate reduction under-predicted the sulfate reduction. When the Cameron-Grace equation for sulfate reduction was multiplied by 11.6, the results were in reasonable agreement for sulfate reduction with experimental data for pyrolysis of black liquor char at $1000^{\circ} \mathrm{C}$. These results are illustrated in Figure 2-7. The authors also reported that the equations proposed by Li and Van Heiningen [26] approximate carbon conversion well, while alternative models for gasification by Whitty et al. and Wåg et al. do not predict the gasification rates well. The model results for gasification did not match the experimental results, as seen in Figure 2-7. 
Table 2-2. Reactions in the PR-FURMO Model.

\begin{tabular}{|l|l|}
\hline 1.Drying & $\mathrm{H}_{2} \mathrm{O}_{(\mathrm{l})} \rightarrow \mathrm{H}_{2} \mathrm{O}_{(\mathrm{g})}$ \\
\hline 2.Devolatilization & $\mathrm{BLSolids}_{(\mathrm{s})} \rightarrow \alpha_{\mathrm{vl}}$ Volatiles $_{(\mathrm{g})}+\alpha_{\mathrm{cs}} \mathrm{C}_{(\mathrm{s})}+\alpha_{\mathrm{io}}$ Inorganics $_{(\mathrm{s})}$ \\
\hline 3.Physical Ejection & $\mathrm{BLSolids}_{(\text {particles })} \rightarrow$ BLSolids $_{(\mathrm{ejecta})}$ \\
\hline 4.Gasification by $\mathrm{CO}_{2}$ & $\mathrm{C}+\mathrm{CO}_{2} \rightarrow 2 \mathrm{CO}$ \\
\hline 5.Gasification by $\mathrm{H}_{2} \mathrm{O}$ & $\mathrm{C}+\mathrm{H}_{2} \mathrm{O} \rightarrow \mathrm{H}_{2}+\mathrm{CO}$ \\
\hline 6. Oxidation by $\mathrm{O}_{2}$ & $\mathrm{C}+0.5\left(2-\mathrm{f}_{\mathrm{c} / \mathrm{o}_{2}}\right) \mathrm{O}_{2} \rightarrow \mathrm{f}_{\mathrm{c} / \mathrm{o}_{2}} \mathrm{CO}+\left(1-\mathrm{f}_{\mathrm{c} / \mathrm{o}_{2}}\right) \mathrm{CO}_{2}$ \\
\hline $\begin{array}{l}\text { 7.Alkali-Sulfate } \\
\text { reduction. }\end{array}$ & $\mathrm{C}+0.25\left(2-\mathrm{f}_{\mathrm{c} / \mathrm{s}}\right) \mathrm{M}_{2} \mathrm{SO}_{4} \rightarrow 0.25\left(2-\mathrm{f}_{\mathrm{c} / \mathrm{s}}\right) \mathrm{M}_{2} \mathrm{~S}+\left(1-\mathrm{f}_{\mathrm{c} / \mathrm{s}}\right) \mathrm{CO}_{2}+\mathrm{f}_{\mathrm{c} / \mathrm{s}} \mathrm{CO}$ \\
\hline $\begin{array}{l}\text { 8.Alkali-Carbonate } \\
\text { reduction by Carbon }\end{array}$ & $\mathrm{C}+\left(2-\mathrm{f}_{\mathrm{c} / \mathrm{c}}\right) \mathrm{M}_{2} \mathrm{CO}_{3} \rightarrow 2\left(2-\mathrm{f}_{\mathrm{c} / \mathrm{ca}}\right) \mathrm{M}_{(\mathrm{g})}+\left(3-2 \mathrm{f}_{\mathrm{c} / \mathrm{ca}}\right) \mathrm{CO}_{2}+\mathrm{f}_{\mathrm{c} / \mathrm{ca}} \mathrm{CO}$ \\
\hline $\begin{array}{l}\text { 9. Alkali-Sulfide } \\
\text { oxidation. }\end{array}$ & $\mathrm{M}_{2} \mathrm{~S}+2 \mathrm{O}_{2} \rightarrow \mathrm{M}_{2} \mathrm{SO}_{4}$ \\
\hline $\begin{array}{l}\text { 10.Alkali-chloride } \\
\text { Vaporization. }\end{array}$ & $\mathrm{MCl}_{(\mathrm{s})} \rightarrow \mathrm{MCl}_{(\mathrm{g})}$ \\
\hline $\begin{array}{l}\text { 11.Alkali-Carbonate } \\
\text { reduction by smelt. }\end{array}$ & $\mathrm{M}_{2} \mathrm{CO}_{3}+\frac{1}{4} \mathrm{M}_{2} \mathrm{~S} \rightarrow \frac{1}{4} \mathrm{M}_{2} \mathrm{SO}_{4}+2 \mathrm{M}_{(\mathrm{g})}+\mathrm{CO}_{2}$ \\
\hline & $\mathrm{Note}_{\mathrm{M} \mathrm{can} \mathrm{be} \mathrm{Na} \mathrm{or} \mathrm{K.}}$ \\
\hline
\end{tabular}

Wåg et al. [29] developed a model to describe sulfate reduction and carbon removal during char burning. This model, built upon the work of Kymäläinen et al. [7], includes gasification of carbon by water vapor and carbon dioxide, direct carbon oxidation by oxygen, reaction between oxygen and combustibles like carbon monoxide in the boundary layer, simultaneous sulfate reduction with carbon and sulfide re-oxidation with oxygen, and volatilization of sodium, in one char particle assumed to be falling at terminal settling velocity in a gas [29].

Comparison of model results with experimental data is presented in Figure 2-8 and the authors claim better prediction of experimental sulfate reduction data. The models by Wåg et al. [29] form the basis for the work presented in Chapters 3 and 4. Hence, a more detailed explanation of the reactions and rate equations will be found in the following chapters. The Wag model for sulfate reduction matches experimental results (see Figure 2-8) with 
reasonable accuracy. Wag et al. investigated the effect of temperature and droplet size on sulfate reduction and the results predict an increase in the time required for 95\% sulfate reduction as the size increases. The results also show that the reduction time decreases with increasing temperature (Figure 2-9.) The variation in char burnout times (the time required for $95 \%$ of the carbon to be consumed) was also reported for temperatures between $900-1100^{\circ} \mathrm{C}$. These results indicate that char burnout time decreases with increasing concentration of $\mathrm{CO}_{2}$ or $\mathrm{H}_{2} \mathrm{O}$ for a given temperature. Char burnout time seems unaffected by $\mathrm{O}_{2}$ concentration for a given temperature. These results are also illustrated in Figure 2-9.

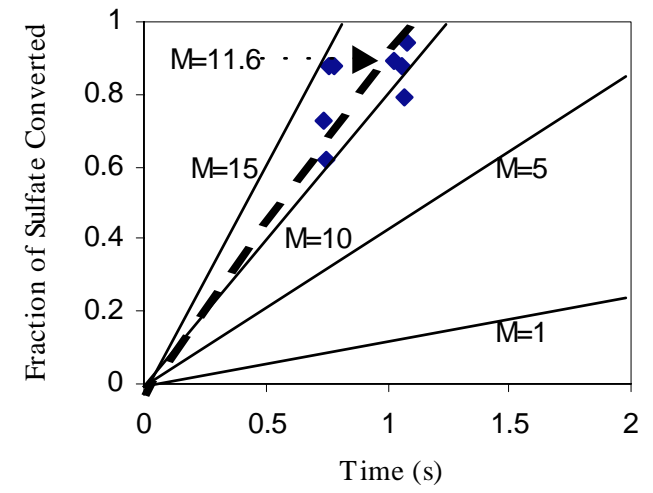

$\mathrm{P}$ yro lys is of chars at $1000^{\circ} \mathrm{C}$. So lid lines indicate predicted reduction based on Cameron-Grace eqn. multiplied by a factor M.

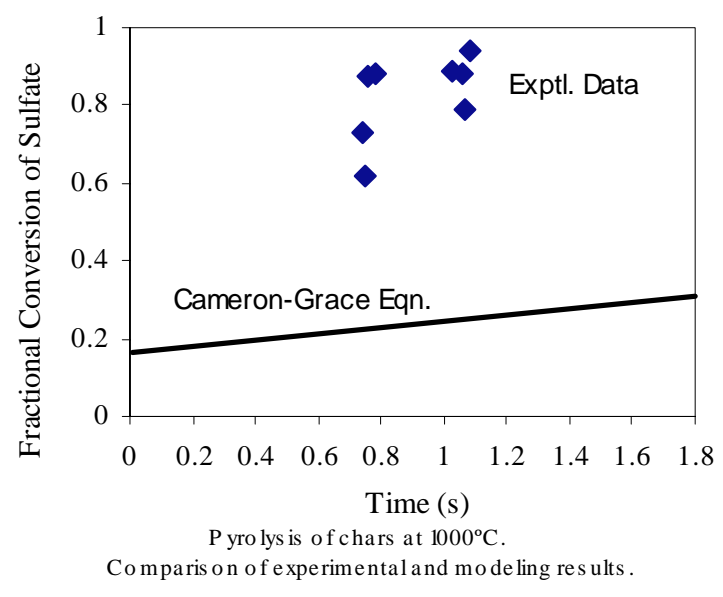

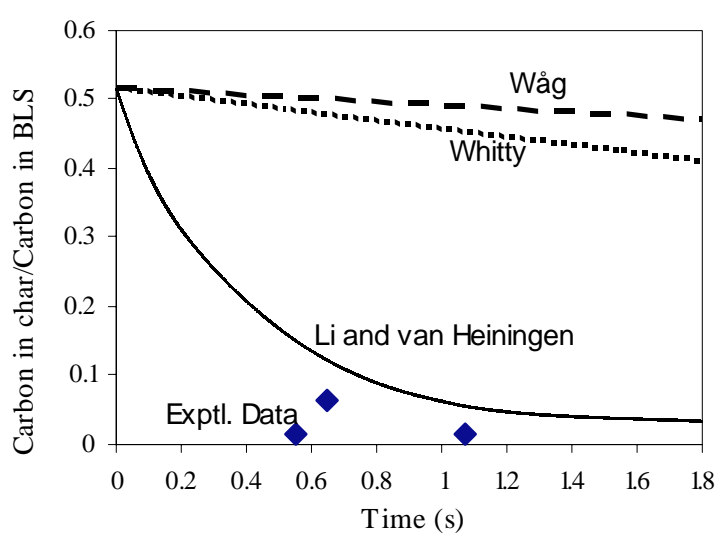

Gas ification of chars at $1000^{\circ} \mathrm{C}$. Comparis on of Gas ific ation Models .

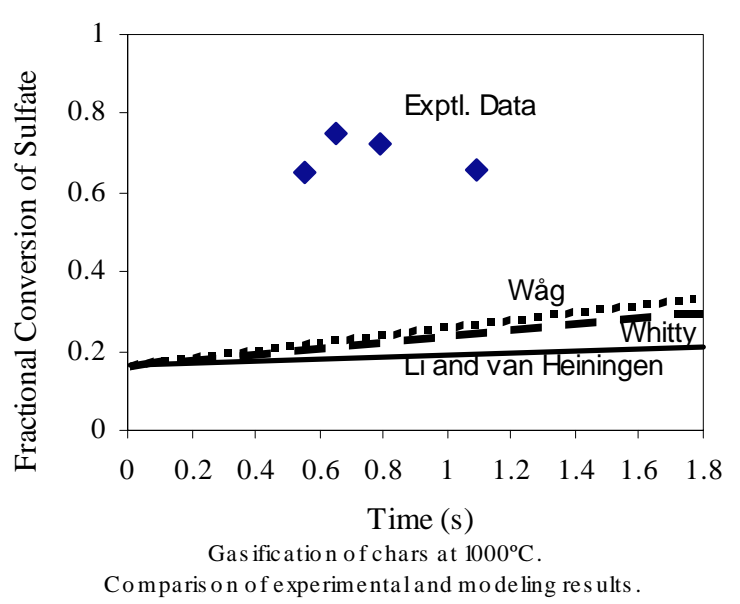

Figure 2-7. Comparison of model and experimental data by Kymäläinen et al. 


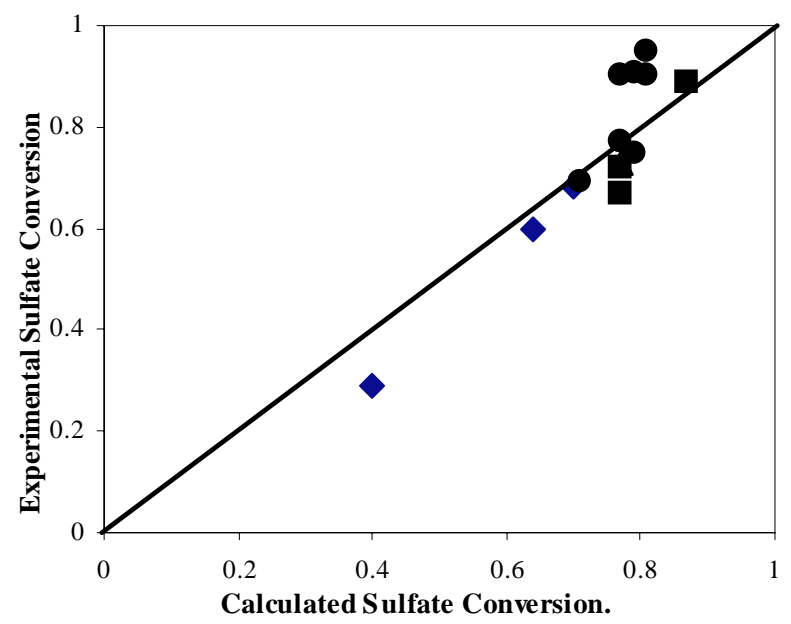

Figure 2-8. Comparison of model and experimental data by Wåg et al.
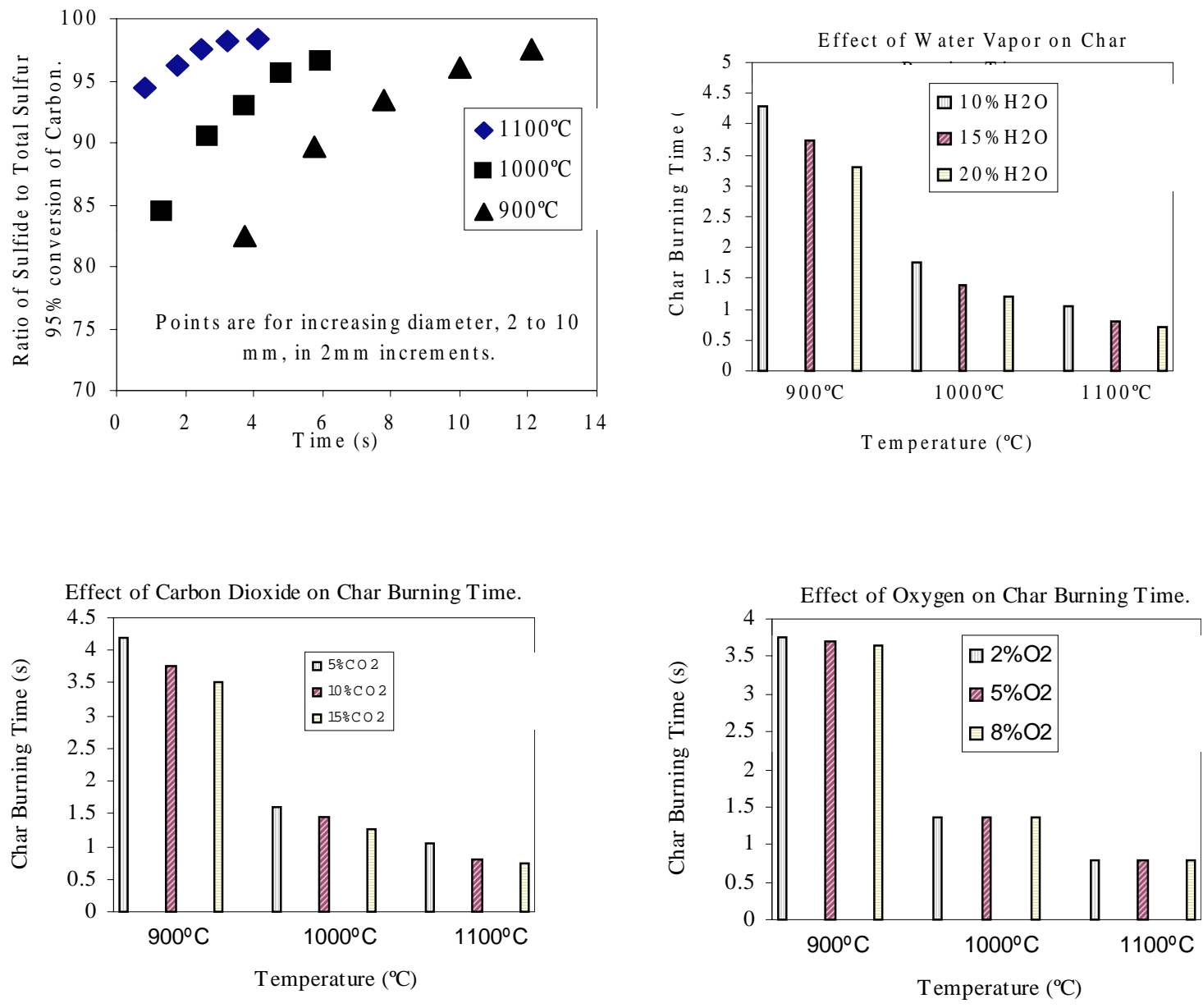

Figure 2-9. Modeling results from Wåg et al. 


\section{CHAPTER 3}

\section{NUMERICAL SIMULATION}

\subsection{Kinetic Models for Black Liquor Chemical Recovery}

While few models are reported in literature, not all of them are easily adaptable to the MFIX software. Work by Wåg [29] contains models for devolatilization of black liquor solids (obtained after the drying stage) and separate model for char burning. The model for devolatilization does not contain rate equations for all the chemical reactions and hence cannot be incorporated into MFIX. This forms a basic limitation in the use of MFIX for modeling different stages in black liquor chemical recovery process.

Different models follow reaction schemes slightly different from each other. The reaction schemes from the works of Wåg et al., [6], Kymäläinen et al., [7] and Sricharoenchaikul et al., [8,9] are reported to match experimental results better than most other models. The basic composition of black liquor char particles consists of sodium sulfate, sodium carbonate, fixed carbon, with small quantities of sulfide, thiosulfate, sulfite of sodium also being present [7,29]. A sample composition of the black liquor char is given in Table 3-1. The gas fed to the Laminar Entrained Flow Reactor (LEFR) consists of $\mathrm{N}_{2}$, during pyrolysis, and a mixture of $\mathrm{N}_{2}, \mathrm{CO}_{2}, \mathrm{CO}, \mathrm{H}_{2}$ and $\mathrm{H}_{2} \mathrm{O}$, during gasification. A sample composition of the feed gas is presented in Table 3-2 [7].

The objective of this research is to develop an integrated model for simulating fluid flow and reaction kinetics during black liquor char burning, in an industrial/experimental setup. This objective is achieved by incorporating the rate equations for chemical reactions 
occurring during char burning into a generic multiphase computational fluid dynamics code (MFIX).

Table 3-1. Sample Composition of Dried Black Liquor Char Particles.

\begin{tabular}{|l|l|}
\hline \multicolumn{1}{|c|}{ Species } & Wt. \% \\
\hline Fixed Carbon, C & 26.7 \\
\hline Sodium, Na & 23.4 \\
\hline Sulfur, S & 5.4 \\
\hline
\end{tabular}

Table 3-2. Sample Composition of Feed Gas.

\begin{tabular}{|c|c|}
\hline Species & Mol. \% \\
\hline \multicolumn{2}{|c|}{ Pyrolysis } \\
\hline Nitrogen, $\mathrm{N}_{2}$ & 100 \\
\hline \multicolumn{2}{|c|}{ Gasification } \\
\hline Nitrogen & 40 \\
\hline Carbon Dioxide & 20 \\
\hline Carbon Monoxide & 10 \\
\hline Hydrogen & 10 \\
\hline Oxygen & 0 \\
\hline Water Vapor & 20 \\
\hline
\end{tabular}

The model presented here is capable of solving microscopic mass, momentum and energy transport equations derived from first principles. It is also capable of simulating actual experimental or industrial reactor and give the variation of process variables with respect to all three dimensions in space and with respect to time. The numerical model presented here is capable of being extended to actual combustors in that it takes into account the following additional details:

1. The effect of temperature and concentration gradients affected by the gas-solid flow profiles.

2. Transport Phenomena in the entrance region of the reactor.

3. Multidimensional effects on the transport phenomena. 
4. All equations are based on first principles. No empirical relationships are used in the formulation of the basic transport equations.

5. Transient effects that would be anticipated in an actual combustor.

6. Unlike earlier models, MFIX simulations did not use empirical equations for predicting the temperature of solids, as our model is capable of solving heat transport equations. The heats of reaction were estimated from data obtained from JANAF Thermochemical Tables [33].

\subsection{The Hydrodynamic Model (MFIX)}

The theoretical foundations of the CFD code MFIX are based on a hydrodynamic theory of multiphase flows. The gas-solid system is assumed to consist of a sufficient number of particles so that discontinuities can be smoothed out and hence various properties can be treated as being continuous.

The fluids and solids in two-phase flows are treated as two interpenetrating continua. The constitutive relationships for such multiphase systems are derived by the use of Reynolds Transport Theorem to principles of conservation of mass, momentum and energy to derive the microscopic form of the conservation laws. The model uses an averaging approach to derive equations that describe interpenetrating continua [32]. The point variables are averaged over a region that is large compared with the particle spacing but much smaller than the flow domain. This CFD code is capable of tracking gas and four different solid phases. Each solid phase is characterized by an unique diameter and density.

The space occupied by one phase cannot be occupied by another at the same time. This leads to the use of volume fractions of the phases in the formulation of all transport relationships. Any reactor is divided into small finite volume cells, over which all the 
conservation equations are integrated. The equations are linearized and solved using linear equation solving techniques. All of these tasks are built into the CFD code, MFIX. MFIX code can be easily modified to incorporate chemical reactions, which form the components of the source terms in the different balance equations. A more detailed account of the equations used and discretization methods can be found in the Theory and Numerical Technique guides for MFIX [32,34]. A description of the basic transport relationships that are incorporated into MFIX are shown below:

Conservation of Mass

The continuity equations for gas and the solid phase are

$$
\begin{aligned}
& \frac{\partial}{\partial \mathrm{t}}\left(\rho_{\mathrm{g}} \varepsilon_{\mathrm{g}}\right)+\nabla \cdot\left(\rho_{\mathrm{g}} \varepsilon_{\mathrm{g}} \overrightarrow{\mathrm{v}}_{\mathrm{g}}\right)=\sum_{\mathrm{n}=1}^{\mathrm{N}_{\mathrm{g}}} \mathrm{R} \mathrm{gn} \\
& \frac{\partial}{\partial \mathrm{t}}\left(\rho_{\mathrm{s}} \varepsilon_{\mathrm{s}}\right)+\nabla \cdot\left(\rho_{\mathrm{s}} \varepsilon_{\mathrm{s}} \overrightarrow{\mathrm{v}}_{\mathrm{s}}\right)=\sum_{\mathrm{n}=1}^{\mathrm{N}_{\mathrm{s}}} \mathrm{R}_{\mathrm{sn}}
\end{aligned}
$$

The first two terms on the left of Equations 3.1 and 3.2 account for the rate of accumulation of mass and net rate of mass outflow through the averaging volume for the gas and solids phases, respectively. The term on the right accounts for rate of generation of mass in the phases though chemical reactions or interphase mass transfer. Though there can be a total of four different solid phases, we only utilize one solids phase in our simulations.

\section{Conservation of Momentum}

The gas phase momentum balance is

$$
\begin{aligned}
\frac{\partial}{\partial t}\left(\rho_{g} \varepsilon_{g} \vec{v}_{g}\right)+\nabla \cdot\left(\rho_{g} \varepsilon_{g} \vec{v}_{g} \vec{v}_{g}\right) & =-\nabla P_{g}+\nabla \cdot \tau_{g}+\rho_{g} \varepsilon_{g} \vec{g}+F_{g s}\left(\vec{v}_{s}-\vec{v}_{g}\right) \\
& -R_{o s}\left(\xi_{o s} \vec{v}_{s}+\bar{\xi}_{o s} \vec{v}_{g}\right)
\end{aligned}
$$


The first two terms on the right of Equations 3.3account for the surface forces expressed in the form of the pressure gradient and gas phase stress tensor. Body forces are accounted for only in terms of the weight of the gas. The last two terms on the right represent the momentum transfer between gas and solid phases due to drag and mass transfer. $R_{o s}$ is the mass transferred from the gas to the solid phase and the value of $\xi_{\text {os }}$ is given by,

$$
\begin{aligned}
& \xi_{\mathrm{os}}=\left\{\begin{array}{l}
1 \text { for } \mathrm{R}_{0 \mathrm{~s}}<0 \\
0 \text { for } \mathrm{R}_{0 \mathrm{~s}} \geq 0
\end{array}\right. \\
& \text { and } \\
& \bar{\xi}_{\mathrm{os}}=1-\xi_{\mathrm{o}}
\end{aligned}
$$

Gas-solid drag is calculated using a modified terminal settling velocity correlation.

$$
\mathrm{F}_{\mathrm{gs}}=\frac{3 \varepsilon_{\mathrm{s}} \rho_{\mathrm{g}}}{4 \mathrm{~V}_{\mathrm{rs}}^{2} \mathrm{~d}_{\mathrm{p}}}\left(0.63+\frac{4.8}{\sqrt{\mathrm{V}_{\mathrm{rs}} / \operatorname{Re}_{\mathrm{s}}}}\right)^{2}\left|\overrightarrow{\mathrm{v}}_{\mathrm{s}}-\overrightarrow{\mathrm{v}}_{\mathrm{g}}\right|
$$

where, $\mathrm{V}_{\mathrm{rs}}$ is the terminal settling velocity correlation for the solid phase. An explicit formula used for calculating $\mathrm{V}_{\mathrm{rs}}$ is of the form

$$
\mathrm{V}_{\mathrm{rs}}=0.5\left(\mathrm{~A}-0.06 \operatorname{Re}_{\mathrm{s}}+\sqrt{\left(0.06 \operatorname{Re}_{\mathrm{s}}\right)^{2}+0.12 \operatorname{Re}_{\mathrm{s}}(2 \mathrm{~B}-\mathrm{A})+\mathrm{A}^{2}}\right)
$$

where,

$$
\begin{aligned}
& \mathrm{A}=\varepsilon_{\mathrm{g}}^{4.14} \text { and } \\
& \mathrm{B}=\left\{\begin{array}{lll}
0.8 \varepsilon_{\mathrm{g}}{ }^{1.28} & \text { if } & \varepsilon_{\mathrm{g}} \leq 0.85 \\
\varepsilon_{\mathrm{g}}^{2.65} & \text { if } & \varepsilon_{\mathrm{g}}>0.85
\end{array}\right.
\end{aligned}
$$

The Reynolds number of the solid phase is given by,

$$
\operatorname{Re}_{\mathrm{s}}=\frac{\mathrm{d}_{\mathrm{p}}\left|\overrightarrow{\mathrm{v}}_{\mathrm{s}}-\overrightarrow{\mathrm{v}}_{\mathrm{g}}\right| \rho_{\mathrm{g}}}{\mu_{\mathrm{g}}}
$$

The gas phase shear stress is calculated by,

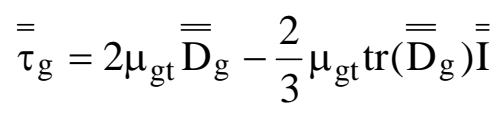


where, $\mu_{\mathrm{gt}}$ is the sum of molecular and turbulent viscosity. The molecular viscosity was assumed constant for simulations of char burning. Equations governing the use and calculation of the turbulent viscosity are found in the theory guide for MFIX [11].

The solid phase momentum balance is

$$
\begin{gathered}
\frac{\partial}{\partial \mathrm{t}}\left(\rho_{\mathrm{s}} \varepsilon_{\mathrm{s}} \overrightarrow{\mathrm{v}}_{\mathrm{s}}\right)+\nabla \cdot\left(\rho_{\mathrm{s}} \varepsilon_{\mathrm{s}} \overrightarrow{\mathrm{v}}_{\mathrm{s}} \overrightarrow{\mathrm{v}}_{\mathrm{s}}\right)=-\nabla \cdot \overline{\overline{\mathrm{S}}}_{\mathrm{s}}+\rho_{\mathrm{s}} \varepsilon_{\mathrm{s}} \overrightarrow{\mathrm{g}}-\mathrm{F}_{\mathrm{gs}}\left(\overrightarrow{\mathrm{v}}_{\mathrm{s}}-\overrightarrow{\mathrm{v}}_{\mathrm{g}}\right) \\
-\mathrm{R}_{\mathrm{osl}}\left(\xi_{\mathrm{os}} \overrightarrow{\mathrm{v}}_{\mathrm{s}}+\bar{\xi}_{\mathrm{os}} \overrightarrow{\mathrm{v}}_{\mathrm{g}}\right)
\end{gathered}
$$

The terms on the right of Equations 3.9 account for the surface forces in the solid phase, body force, gas-solid interphase drag, gas-solid and solid-solid momentum transfer due to mass transfer, and solid-solid drag, respectively. The momentum balance for the solids phase ignores solids pressure and assumes that none of the gas phase pressure drop resides in the solids phase momentum balance ([35]: Model B).

Kinetic theory was utilized to develop the stress tensor in the solid phase. The resulting relationship contains a quantity called "granular temperature", which is proportional to the specific kinetic energy of the random fluctuating component of the particle velocity. The conservation rule for the transport of granular energy in the solid phase is of the form

$$
\frac{3}{2}\left[\frac{\partial}{\partial \mathrm{t}}\left(\rho_{\mathrm{s}} \varepsilon_{\mathrm{s}} \Theta_{\mathrm{s}}\right)+\nabla \cdot\left(\rho_{\mathrm{s}} \varepsilon_{\mathrm{s}} \Theta_{\mathrm{s}}\right) \overrightarrow{\mathrm{v}}_{\mathrm{s}}\right]=\overline{\overline{\mathrm{S}}}_{\mathrm{s}}: \nabla \overrightarrow{\mathrm{v}}_{\mathrm{s}}-\nabla \cdot \overrightarrow{\mathrm{q}}_{\theta_{\mathrm{s}}}-\gamma_{\theta_{\mathrm{s}}}+\phi_{\mathrm{gs}}
$$

where $\gamma_{\theta_{\mathrm{s}}}$ is the rate of granular energy dissipation due to inelastic collisions, and $q_{\theta_{\mathrm{s}}}$ is the diffusive flux of granular energy, $\phi_{\mathrm{gs}}$ accounts for the transfer of granular energy between the gas and solid phases.

To simplify the numerical computation of Equation 3.10, it was assumed that the accumulation terms on the left were negligible. This assumption results in the granular 
temperature being expressed in an algebraic equation instead of a partial differential equation as given $[11,12]$

$$
\Theta \mathrm{s}=\left\{\frac{\varepsilon_{\mathrm{s}} \mathrm{K}_{4 \mathrm{~s}} \operatorname{tr}\left(\overline{\bar{D}}_{\mathrm{s}}\right)+\sqrt{\mathrm{K}_{1 \mathrm{~s}}^{2} \operatorname{tr}^{2}\left(\overline{\bar{D}}_{\mathrm{s}}\right)_{\mathrm{s}}^{2}+4 \varepsilon_{\mathrm{s}} \mathrm{K}_{4 \mathrm{~s}}\left[\mathrm{~K}_{2 \mathrm{~s}} \mathrm{tr}^{2}\left(\overline{\bar{D}}_{\mathrm{s}}\right)+2 \mathrm{~K}_{3 \mathrm{~s}} \mathrm{tr}\left(\overline{\overline{\mathrm{D}_{\mathrm{s}}^{2}}}\right)\right]}}{2 \varepsilon_{\mathrm{s}} \mathrm{K}_{4 \mathrm{~s}}}\right\}^{2}
$$

The granular stress term in the momentum balance for the mth solid phase is computed in the following manner [11].

$$
\overline{\overline{\mathrm{S}}}_{\mathrm{s}}= \begin{cases}\overline{\bar{\tau}_{\mathrm{p}}^{\mathrm{p}}} & \text { if } \varepsilon_{\mathrm{g}} \leq \varepsilon_{\mathrm{g}}^{*} \\ \overline{\bar{\tau}} & \text { if } \varepsilon_{\mathrm{g}}>\varepsilon_{\mathrm{g}}^{*}\end{cases}
$$

where $\varepsilon_{\mathrm{g}}^{*}$ is the void fraction when the solids are closely packed. Equations 3.13 and 3.14 apply when the void fraction is greater than $\varepsilon_{\mathrm{g}}^{*}$. The stress tensor for the solid phase in viscous flow conditions is given by

$$
\bar{\tau}_{\mathrm{s}}^{\mathrm{v}}=\lambda_{\mathrm{s}}^{\mathrm{v}} \operatorname{tr}\left(\overline{\overline{\mathrm{D}}}_{\mathrm{s}}\right) \overline{\overline{\mathrm{I}}}+2 \mu_{\mathrm{s}}^{\mathrm{v}} \overline{\overline{\mathrm{D}}}_{\mathrm{s}}
$$

where

$$
\begin{aligned}
& \lambda_{\mathrm{s}}^{\mathrm{v}}=\mathrm{K}_{2 \mathrm{~s}} \varepsilon_{\mathrm{s}} \sqrt{\Theta_{\mathrm{s}}} \\
& \mu_{\mathrm{s}}^{\mathrm{v}}=\mathrm{K}_{3 \mathrm{~s}} \varepsilon_{\mathrm{s}} \sqrt{\Theta_{\mathrm{s}}}
\end{aligned}
$$

\section{Conservation of Energy}

The energy balance for the gas phase is written in the convective form as follows:

$$
\begin{aligned}
\rho_{\mathrm{g}} \varepsilon_{\mathrm{g}} \mathrm{C}_{\mathrm{Pg}}\left(\frac{\partial \mathrm{T}_{\mathrm{g}}}{\partial \mathrm{t}}+\overrightarrow{\mathrm{v}}_{\mathrm{g}} \cdot \nabla \mathrm{T}_{\mathrm{g}}\right)=-\nabla \cdot \overrightarrow{\mathrm{q}}_{\mathrm{g}}+\gamma_{\mathrm{gs}}\left(\mathrm{T}_{\mathrm{s}}-\mathrm{T}_{\mathrm{g}}\right) & -\sum_{\mathrm{i}=1}^{\mathrm{n}} \mathrm{R}_{\mathrm{i}} \Delta \mathrm{H}_{\mathrm{rg}, \mathrm{i}} \\
& +\mathrm{H}_{\text {wall }}\left(\mathrm{T}_{\text {wall }}-\mathrm{T}_{\mathrm{g}}\right)
\end{aligned}
$$


Terms on the right are the gas-phase conductive heat flux, gas-solids interphase heat transfer, the rate of heat generation in the gas phase, and the heat loss to the wall tough convection, respectively. In simulations of char burning, we assumed the reactor was adiabatic $\left(\mathrm{H}_{\text {wall }}=0\right)$ and the effect of radiation was negligible. The gas-solid heat transfer coefficient, $\gamma_{\mathrm{gs}}$, is determined from the heat transfer coefficient in the absence of mass transfer $\left(\gamma_{\mathrm{gs}}^{\mathbf{o}}\right)$, and then corrected for interphase mass transfer by using the following equations derived from film theory [11].

$$
\begin{aligned}
& \gamma_{\mathrm{gs}}^{\mathrm{o}}=\frac{6 \mathrm{k}_{\mathrm{g}} \varepsilon_{\mathrm{s}} \mathrm{Nu}_{\mathrm{s}}}{\mathrm{d}_{\mathrm{p}}{ }^{2}} \\
& \gamma_{\mathrm{gs}}=\frac{\mathrm{C}_{\mathrm{Pg}} \mathrm{R}_{\mathrm{os}}}{\mathrm{e}^{\left(\mathrm{C}_{\mathrm{gg}} \mathrm{R}_{0 \mathrm{~s}} / \gamma_{\mathrm{gs}}^{\mathrm{o}}\right)}-1}
\end{aligned}
$$

The Nusselt number for the individual particles constituting the solids phase is determined using a correlation applicable for a porosity range of $0.35-1.0$ and a Reynolds number up to $10^{5}[14]$

$$
\mathrm{Nu}_{\mathrm{s}}=\left(7-10 \varepsilon_{\mathrm{s}}+5 \varepsilon_{\mathrm{s}}{ }^{2}\right)\left(1+0.7 \operatorname{Re}_{\mathrm{s}}^{0.2} \operatorname{Pr}^{1 / 3}\right)+\left(1.3-2.4 \varepsilon_{\mathrm{s}}+1.2 \varepsilon_{\mathrm{s}}{ }^{2}\right) \operatorname{Re}_{\mathrm{s}}^{0.7} \operatorname{Pr}^{1 / 3}
$$

The energy balance for the solid phase is similarly expressed in a convective form as:

$$
\rho_{\mathrm{s}} \varepsilon_{\mathrm{s}} \mathrm{C}_{\mathrm{Ps}}\left(\frac{\partial \mathrm{T}_{\mathrm{s}}}{\partial \mathrm{t}}+\overrightarrow{\mathrm{v}}_{\mathrm{s}} \cdot \nabla \mathrm{T}_{\mathrm{s}}\right)=-\nabla \cdot \overrightarrow{\mathrm{q}}_{\mathrm{s}}+\gamma_{\mathrm{gs}}\left(\mathrm{T}_{\mathrm{s}}-\mathrm{T}_{\mathrm{g}}\right)-\sum_{\mathrm{j}=1}^{\mathrm{n}} \mathrm{R}_{\mathrm{j}} \Delta \mathrm{H}_{\mathrm{rs}, \mathrm{j}}
$$

where the rate of heat generation pertains to chemical reactions occurring in the solids phase and a specified fraction of the heat generation for gas-solid reactions that involve species in both phases. 


\section{Species Balance Equations}

The species conservation equation for the gas and solid phases are

$$
\begin{gathered}
\frac{\partial}{\partial t}\left(\varepsilon_{\mathrm{g}} \rho_{\mathrm{g}} \mathrm{X}_{\mathrm{gn}}\right)+\nabla \cdot\left(\varepsilon_{\mathrm{g}} \rho_{\mathrm{g}} \mathrm{X}_{\mathrm{gn}} \overrightarrow{\mathrm{v}}_{\mathrm{g}}\right)=\nabla \cdot \mathrm{D}_{\mathrm{gn}} \nabla \cdot \mathrm{X}_{\mathrm{gn}}+\mathrm{R}_{\mathrm{gn}} \\
\frac{\partial}{\partial \mathrm{t}}\left(\varepsilon_{\mathrm{s}} \rho_{\mathrm{s}} \mathrm{X}_{\mathrm{sm}}\right)+\nabla \cdot\left(\varepsilon_{\mathrm{s}} \rho_{\mathrm{s}} \mathrm{X}_{\mathrm{sm}} \overrightarrow{\mathrm{v}}_{\mathrm{s}}\right)=\mathrm{R}_{\mathrm{sm}}
\end{gathered}
$$

where $X_{(\mathrm{gn} / \mathrm{sm})}$ is the mass fraction of the particular species and $R_{(\mathrm{gn} / \mathrm{sm})}$ is the rate of formation of the species- $\mathrm{n} / \mathrm{m}$. The rate of formation of species-n is calculated from the chemical reactions rate equations. The above equations consider the accumulation, convection, consumption or formation due to chemical reaction and the diffusive flux of species in the gas phase

The above list of constitutive relationships illustrates the equations built into MFIX to solve multiphase flow problems [32]. MFIX also lends itself to easy modification and many of the sections dealing with different aspects of the problem can be modified. This is critical in giving the modeler the ability to fine-tune things to any extent. The most important reason for using a sophisticated software like MFIX, is the ability to generate results for most reactor configurations, over a wide range of conditions and study the performance over all the dimensions of space as well as that of time.

\subsection{Chemical Reaction Rate Equations}

The scheme of reactions incorporated was based on the work of Wåg et al. [29]. A set of ten reactions was chosen to be incorporated into MFIX, as shown in Table 3-3. Reactions I and VI in the table are considered to be a homogenous reactions occurring in the solid phase (black liquor char particles) and are chemical reaction controlled. 
Reactions II, III, IV, V, IX, X in the table are gas-solid reactions and reactions VII and VIII occur in the gas phase only. The rate equations for each of these reactions (Table 3-3) are described below.

Table 3-3. List of Reactions Added to MFIX Routines.

\begin{tabular}{|c|c|}
\hline \multicolumn{2}{|l|}{ Sulfate Reduction } \\
\hline I. $\mathrm{Na}_{2} \mathrm{SO}_{4}+2 \mathrm{C} \rightarrow \mathrm{Na}_{2} \mathrm{~S}+2 \mathrm{CO}_{2}$ & $\Delta \mathrm{H}_{\mathrm{R} 298 \mathrm{~K}}=54.43 \mathrm{kcal} / \mathrm{gmol}$ \\
\hline \multicolumn{2}{|l|}{ Gasification of Carbon } \\
\hline $\begin{array}{l}\text { II. } \mathrm{C}+\mathrm{CO}_{2} \rightarrow 2 \mathrm{CO} \\
\text { III. } \mathrm{C}+\mathrm{H}_{2} \mathrm{O} \rightarrow \mathrm{CO}+\mathrm{H}_{2}\end{array}$ & $\begin{aligned} & \Delta \mathrm{H}_{\mathrm{R} 298 \mathrm{~K}}=41.22 \mathrm{kcal} / \mathrm{gmol} \\
& \Delta \mathrm{H}_{\mathrm{R} 298 \mathrm{~K}}=31.38 \mathrm{kcal} / \mathrm{gmol}\end{aligned}$ \\
\hline \multicolumn{2}{|l|}{ Sulfide Reoxidation } \\
\hline $\begin{array}{l}\text { IV. } \mathrm{Na}_{2} \mathrm{~S}+2 \mathrm{CO}_{2} \rightarrow \mathrm{Na}_{2} \mathrm{CO}_{3}+\mathrm{COS} \\
\text { V. } \mathrm{Na}_{2} \mathrm{~S}+\mathrm{CO}_{2}+\mathrm{H}_{2} \mathrm{O} \rightarrow \mathrm{Na}_{2} \mathrm{CO}_{3}+\mathrm{H}_{2} \mathrm{~S}\end{array}$ & $\begin{array}{r}\Delta \mathrm{H}_{\mathrm{R} 298 \mathrm{~K}}=-27.73 \mathrm{kcal} / \mathrm{gmol} \\
\Delta \mathrm{H}_{\mathrm{R} 298 \mathrm{~K}}=-35.8 \mathrm{kcal} / \mathrm{gmol}\end{array}$ \\
\hline \multicolumn{2}{|l|}{ Sodium Vapor Release } \\
\hline V. $\mathrm{Na}_{2} \mathrm{CO}_{3}+2 \mathrm{C} \rightarrow 2 \mathrm{Na}+3 \mathrm{CO}$ & $\Delta \mathrm{H}_{\mathrm{R} 298 \mathrm{~K}}=-79.25 \mathrm{kcal} / \mathrm{gmol}$ \\
\hline \multicolumn{2}{|l|}{ Reactions Involving Oxygen } \\
\hline $\begin{array}{l}\text { VII. } \mathrm{CO}+0.5 \mathrm{O}_{2} \rightarrow \mathrm{CO}_{2} \\
\text { VIII. } \mathrm{H}_{2}+0.5 \mathrm{O}_{2} \rightarrow \mathrm{H}_{2} \mathrm{O} \\
\text { IX C }+\mathrm{O}_{2} \rightarrow \mathrm{CO}_{2} \\
X . \mathrm{Na}_{2} \mathrm{~S}+2 \mathrm{O}_{2} \rightarrow \mathrm{Na}_{2} \mathrm{SO}_{4}\end{array}$ & $\begin{array}{r}\Delta \mathrm{H}_{\mathrm{R} 298 \mathrm{~K}}=-67.63 \mathrm{kcal} / \mathrm{gmol} \\
\Delta \mathrm{H}_{\mathrm{R} 298 \mathrm{~K}}=-57.79 \mathrm{kcal} / \mathrm{gmol} \\
\Delta \mathrm{H}_{\mathrm{R} 298 \mathrm{~K}}=-94.05 \mathrm{kcal} / \mathrm{gmol} \\
\Delta \mathrm{H}_{\mathrm{R} 298 \mathrm{~K}}=-242.54 \mathrm{kcal} / \mathrm{gmol}\end{array}$ \\
\hline
\end{tabular}

\subsubsection{Sulfate Reduction}

Two different rate expressions were found in the literature for sulfate reduction by carbon (Reaction I in Table 3.3). Cameron and Grace [23] developed an expression for the reduction of sulfate based on experiments conducted between $760-844^{\circ} \mathrm{C}$.

$$
\mathrm{r}_{\mathrm{Na}_{2} \mathrm{SO}_{4}}=1310\left(\frac{\left[\mathrm{SO}_{4}\right]}{0.22+\left[\mathrm{SO}_{4}\right]}\right)[\mathrm{C}] \mathrm{e}^{(-\mathrm{E} / \mathrm{RT})}
$$

where, $\mathrm{r}_{\mathrm{Na} 2 \mathrm{SO} 4}=$ Rate of sulfate reduction $\left(\mathrm{kmol} / \mathrm{m}^{3} \mathrm{~s}\right)$

$[\mathrm{SO} 4]=$ concentration of sulfate. $\left(\mathrm{kmol} / \mathrm{m}^{3}\right)$

$[\mathrm{C}]=$ Concentration of Carbon $\left(\mathrm{kmol} / \mathrm{m}^{3}\right)$

$\mathrm{E}=$ Activation Energy $=29,200(\mathrm{cal} / \mathrm{mol})$ 
Wåg et al. [29] reported that the above equation under-predicts sulfate reduction and published an alternative equation developed from experimental data from combustion of different black liquor chars at $900-1100^{\circ} \mathrm{C}$.

$$
\mathrm{r}_{\mathrm{Na}_{2} \mathrm{SO}_{4}}=3790\left[\mathrm{SO}_{4}\right]_{1}^{1.4}[\mathrm{C}] \mathrm{e}^{(-E / \mathrm{RT})}
$$

where, $\mathrm{r}_{\mathrm{Na} 2 \mathrm{SO} 4}=$ Rate of sulfate reduction $\left(\mathrm{mol} / \mathrm{cm}^{3} \mathrm{~s}\right)$

$[\mathrm{SO} 4]_{1}=$ Ratio of Sodium Sulfate to total Sodium. $\left(\mathrm{mol} \mathrm{Na}_{2} \mathrm{SO}_{4} / \mathrm{mol} \mathrm{Na}_{2}\right)$

$[\mathrm{C}]=$ Concentration of Carbon $\left(\mathrm{mol} / \mathrm{cm}^{3}\right)$

$\mathrm{E}=$ Activation Energy $=18700(\mathrm{cal} / \mathrm{mol})$

\subsubsection{Gasification}

Carbon is also consumed by $\mathrm{CO}_{2}$ and $\mathrm{H}_{2} \mathrm{O}$, as shown by Reactions II and III in Table 3.3. The chemical kinetic rate $\left(\mathrm{R}_{\mathrm{ci}}\right)$ is given by Equations 3.22 and 3.23 , which are expressions for the amount of carbon consumed by $\mathrm{H}_{2} \mathrm{O}$ and $\mathrm{CO}_{2}$ respectively. These intrinsic reaction kinetics were developed by $\mathrm{Li}$ et al. [5] from experimental data for char carbon gasification in a Thermogravimetric Analyzer between $700-800^{\circ} \mathrm{C}$. Li et al. report that gasification of carbon by $\mathrm{CO}_{2}$ and $\mathrm{H}_{2} \mathrm{O}$ are first order with respect to carbon and a LangmuirHinshelwood type of kinetic dependence on the composition of gas phase species.

$$
\mathrm{r}_{\mathrm{C}, \mathrm{CO} 2}=63 \times 10^{9}[\mathrm{C}]\left(\frac{\mathrm{P}_{\mathrm{CO} 2}}{\mathrm{P}_{\mathrm{CO} 2}+3.4 \mathrm{P}_{\mathrm{CO}}}\right) \mathrm{e}^{(-\mathrm{E} / \mathrm{RT})}
$$

where, $\mathrm{r}_{\mathrm{C}, \mathrm{CO} 2}=$ Rate of carbon consumption by $\mathrm{CO}_{2}\left(\mathrm{~mol} / \mathrm{cm}^{3} \mathrm{~s}\right)$

$\mathrm{P}_{\mathrm{i}}=$ Partial Pressure of component $\mathrm{i}$ in bulk gas phase. (Bar)

$[\mathrm{C}]=$ Concentration of Carbon $\left(\mathrm{mol} / \mathrm{cm}^{3}\right)$

$\mathrm{E}=$ Activation Energy $=15133.36(\mathrm{cal} / \mathrm{mol})$ 


$$
\mathrm{r}_{\mathrm{C}, \mathrm{H} 2 \mathrm{O}}=2.56 \times 10^{9}[\mathrm{C}]\left(\frac{\mathrm{P}_{\mathrm{H} 2 \mathrm{O}}}{\mathrm{P}_{\mathrm{H} 2 \mathrm{O}}+1.42 \mathrm{P}_{\mathrm{H} 2}}\right) \mathrm{e}^{(-\mathrm{E} / \mathrm{RT})}
$$

$\mathrm{r}_{\mathrm{C}, \mathrm{CO} 2}=$ Rate of carbon consumption by $\mathrm{H}_{2} \mathrm{O}\left(\mathrm{mol} / \mathrm{cm}^{3} \mathrm{~s}\right)$

$P_{i}=$ Partial Pressure of component $i$ in bulk gas phase. (Bar)

$[C]=$ Concentration of Carbon $\left(\mathrm{mol} / \mathrm{cm}^{3}\right)$

$\mathrm{E}=$ Activation Energy $=12732.76(\mathrm{cal} / \mathrm{mol})$

Based on the work of Wag et al.[29], the dominant resistances for these heterogeneous reactions are the resistance due to external and internal mass transfer, and intrinsic chemical reaction resistance. The overall rate of reaction is expressed with a Thiele modulus as follows:

$$
\frac{1}{\mathrm{R}_{\mathrm{i}}}=\frac{1}{\mathrm{R}_{\mathrm{mi}}}+\frac{1}{\eta_{\mathrm{i}} \mathrm{R}_{\mathrm{ci}}}
$$

The overall rate of reaction consists of two parts. They are, $R_{m i}$, the rate of mass transfer of component $i$, and $R_{c i}$, the kinetic rate of reaction of component $i$, with the $\eta_{i}$ (effectiveness factor) accounting for intra-particular diffusion. The rate limiting effect of intra-particle diffusion $\left(\eta_{i}\right)$ is given by

$$
\eta_{\mathrm{i}}=\frac{\tanh \left(\mathrm{M}_{\mathrm{ti}}\right)}{\mathrm{M}_{\mathrm{ti}}}
$$

$\mathrm{M}_{\mathrm{Ti}}$ is the Thiele modulus and is computed using Equations 3.26 and 3.27.

$$
\begin{gathered}
M_{t i}=\frac{d_{p}}{6\left(k_{r, i} / \mathcal{D}_{i}\right)^{0.5}} \\
\mathrm{k}_{\mathrm{r}, \mathrm{i}}=\frac{\mathrm{R}_{\mathrm{ci}}}{\left(\mathrm{V}_{\mathrm{p}} \mathrm{C}_{\mathrm{i}}\right)}
\end{gathered}
$$


The term $\mathrm{k}_{\mathrm{r}, \mathrm{i}}$ in equation 3.26 refers to the apparent first order rate constant calculated from the equation for the kinetic rate, $\mathrm{R}_{\mathrm{c} i}$, by equation 3.27 .

The rate of mass transfer through the film, $R_{m i}$, is modeled as,

$$
\mathrm{R}_{\mathrm{mi}}=\mathrm{kg}_{\mathrm{i}} \mathrm{A}_{\text {ext }}\left(\mathrm{C}_{\mathrm{i} \text { Bulk }}-\mathrm{C}_{\mathrm{i} \text { Interface }}\right)
$$

The mass transfer coefficient, $\mathrm{k}_{\mathrm{gi}}$, was calculated using a correlation developed by D.J. Gunn [14] as shown in equation 3.29. This correlation is valid for a porosity range of $0.35-1.0$ and a Reynolds number up to $10^{5}$. Further details can be found in Appendix A.

$$
\mathrm{N}_{\mathrm{SHi}}=\left(7-10 \varepsilon_{\mathrm{s}}+5 \varepsilon_{\mathrm{s}}{ }^{2}\right)\left(1+0.7 \operatorname{Re}^{0.2} \mathrm{~N}_{\mathrm{SCi}}^{\frac{1}{3}}\right)+\left(1.3-2.4 \varepsilon_{\mathrm{s}}+1.2 \varepsilon_{\mathrm{s}}{ }^{2}\right) \operatorname{Re}^{0.7} \mathrm{~N}_{\mathrm{SCi}}^{\frac{1}{3}}
$$

\subsubsection{Sulfide Reoxidation}

According to $\mathrm{Li}$ et al. [5] the sulfide reoxidation reactions (Reactions IV and $\mathrm{V}$ in Table 3.3) are governed by film mass transfer resistance only. Since they are assumed to be at equilibrium, these reactions are limited by the equilibrium partial pressures of carbonyl sulfide and hydrogen sulfide in the gas film surrounding the particle.

The formation of hydrogen sulfide and carbonyl sulfide are given by Equations 3.30 and 3.31. Here, $X_{\mathrm{s}}$ is the fraction of sodium sulfide that has reacted.

$$
\mathrm{r}_{\mathrm{COS}}=\mathrm{k}_{\mathrm{gcos}} \frac{\mathrm{A}_{\text {ext }}}{\mathrm{V}_{\text {particle }}}[\mathrm{COS}]_{\mathrm{eq}}\left(1-\mathrm{X}_{\mathrm{s}}\right)
$$

where, $\mathrm{r}_{\mathrm{COS}}=$ Rate of formation of carbonyl sulfide $\left(\mathrm{mol} / \mathrm{cm}^{3} \mathrm{~s}\right)$

$[\mathrm{COS}]_{\mathrm{eq}}=$ Equilibrium concentration of carbonyl sulfide $\left(\mathrm{mol} / \mathrm{cm}^{3}\right)$ $\mathrm{X}_{\mathrm{s}}=$ Fraction of sodium sulfide that has reacted . 


$$
\mathrm{r}_{\mathrm{H}_{2} \mathrm{~S}}=\mathrm{k}_{\mathrm{gH} 2 \mathrm{~S}} \frac{\mathrm{A}_{\text {ext }}}{\mathrm{V}_{\text {particle }}}[\mathrm{H} 2 \mathrm{~S}]_{\mathrm{eq}}\left(1-\mathrm{X}_{\mathrm{s}}\right)
$$

where, $\mathrm{r}_{\mathrm{H} 2 \mathrm{~S}}=$ Rate of formation of hydrogen sulfide $\left(\mathrm{mol} / \mathrm{cm}^{3} \mathrm{~s}\right)$

$\left[\mathrm{H}_{2} \mathrm{~S}\right]_{\mathrm{eq}}=$ Equilibrium concentration of hydrogen sulfide $\left(\mathrm{mol} / \mathrm{cm}^{3}\right)$

$\mathrm{X}_{\mathrm{s}}=$ Fraction of sodium sulfide that has reacted .

$$
\left(1-\mathrm{X}_{\mathrm{s}}\right)=\frac{\left[\mathrm{Na}_{2} \mathrm{~S}\right]_{\mathrm{t}}}{\left(\left[\mathrm{Na}_{2} \mathrm{SO}_{4}\right]+\left[\mathrm{Na}_{2} \mathrm{~S}\right]\right)_{\text {initial }}}
$$

Calculation of quantities like, the mass transfer coefficients, $\mathrm{k}_{\mathrm{gCOS}}$ and $\mathrm{k}_{\mathrm{gH} 2 \mathrm{~S}}$, and the equilibrium concentrations of $\mathrm{H}_{2} \mathrm{~S}$ and COS are illustrated in the Appendix B.

\subsubsection{Sodium Vapor Release}

Sodium vapor release reaction (Reaction VI in Table 1.1) is assumed to be controlled by intrinsic chemical kinetics. Sodium release is significant only at higher temperatures $\left(\sim 800^{\circ} \mathrm{C}\right)$. Li et al. [5] suggested that this reaction is suppressed by the presence of $\mathrm{CO}$ and $\mathrm{CO}_{2}$ in the gas phase. However, Wag et al. suggest that this effect was negligible at $1000^{\circ} \mathrm{C}$ for typical furnace conditions and suggested the following equation.

$$
\mathrm{r}_{\mathrm{Na}_{2} \mathrm{CO}_{3}}=2 \times 10^{9}\left[\mathrm{Na}_{2} \mathrm{CO}_{3}\right] \mathrm{e}^{(-29335 / \mathrm{T})}
$$

where, $\mathrm{r}_{\mathrm{Na} 2 \mathrm{CO} 3}=$ Rate of consumption of $\mathrm{Na}_{2} \mathrm{CO}_{3}\left(\mathrm{~mol} / \mathrm{cm}^{3} \mathrm{~s}\right)$

$\left[\mathrm{Na}_{2} \mathrm{CO}_{3}\right]=$ Concentration of $\mathrm{Na}_{2} \mathrm{CO}_{3}\left(\mathrm{~mol} / \mathrm{cm}^{3}\right)$

$\mathrm{E}=$ Activation Energy $=14763.46(\mathrm{cal} / \mathrm{mol})$

\subsubsection{Reactions Involving Oxygen}

Consumption of oxygen is assumed to be controlled by mass transfer only [6]. The rate of mass transfer of oxygen is given by,

$$
\mathrm{R}_{\mathrm{mO}_{2}}=\mathrm{kg}_{\mathrm{O}_{2}} \mathrm{~A}_{\mathrm{ext}} \mathrm{PO}_{2} / \mathrm{RT}
$$


There are four different ways in which oxygen is consumed, as shown by Reactions VII to $\mathrm{X}$ in Table 3-3. This process is modeled as follows,

- Each $\mathrm{CO}$ released from the particle reacts with $0.5 \mathrm{O}_{2}$ to form $\mathrm{CO}_{2}$.

- Each $\mathrm{H}_{2}$ released from the particle reacts with $0.5 \mathrm{O}_{2}$ to form $\mathrm{H}_{2} \mathrm{O}$.

- The remaining $\mathrm{O}_{2}$ (if any) reacts with both $\mathrm{Na}_{2} \mathrm{~S}$ and fixed carbon.

- A fraction "p" (equal to the mole fraction of carbon in the solid phase) of the oxygen eventually reaching the particle surface reacts with carbon, while the rest "(1-p)" reacts with $\mathrm{Na}_{2} \mathrm{~S}$.

Lack of kinetic data for these reactions occurring in parallel was cited as a reason for the use of such a parameter [6].

\subsection{Modification of MFIX Routines}

MFIX routines are modified to incorporate these reaction equations and the associated equations for the various quantities. Calculation of consumption and production of various species, net mass transfer from solid to gas phase and so on, involve many conditional requirements. The modified routines and a sample data file specifying the dimensions of the reactor, initial and boundary conditions etc., are presented in Appendices $\mathrm{C}$ through $\mathrm{E}$. The equations and constants used to calculate specific heat capacities and heats of formation of different species is illustrated in Appendix F.

\subsubsection{Issues with Convergence of Simulations}

The simulations of LEFR have exhibited some unique problems with respect to the use of MFIX for such simulations. Firstly, the reactor does not have substantial amount of solids flowing in it and a major part of the reactor does not have any solids flow at all. This presents 
some unique problem of modifying the routines to account for the absence of solids in any finite-volume cell. Also, the narrow inlet through which solids enter places some restriction on choosing grid sizes.

The reactor is empty (no solids) at the beginning, and the solids enter the reactor and flow downwards, creating a moving interface between a region with solids and one with no solids. This moving interface, along with strong gradients in species concentration and temperatures at the inlet, contributes to very slow convergence. The solution to this, as with many finite volume simulations, is to have very small grid sizes and small time steps. Even with relatively few cells (a two-dimensional reactor instead of a three-dimensional reactor), the time step needs to be around $10^{-5}$ to ensure convergence during the initial 2 seconds of reactor operation (real time). Constraints of computing capacity and the need to achieve results in a meaningful amount of time represent the nature of trade-off that are made in this and other such simulations. The presence of at least eight species in the gas phase and four species in the solid phase makes the convergence of simulations, a slow process. 


\section{CHAPTER 4}

\section{RESULTS AND DISCUSSION}

\subsection{Laminar Entrained Flow Reactor}

A LEFR consists of a tube (as shown in Figure 4-1), $7 \mathrm{~cm}$ diameter $1 \mathrm{~m}$ long [29]. The solid particles (90-125 microns) are entrained in a primary gas stream consisting of $\mathrm{N}_{2}(0.15$ $\mathrm{L} / \mathrm{min} \mathrm{NTP}$ ) at a feed rate of $1.0 \mathrm{~g} / \mathrm{min}$ of solids. For experiments involving pyrolysis, a stream of $\mathrm{N}_{2}$, co-current with the entering stream of particles is fed at the rate of $20 \mathrm{~L} / \mathrm{min}$ (NTP), while gasification is usually done with a stream consisting of $20 \% \mathrm{CO}_{2}, 20 \% \mathrm{H}_{2} \mathrm{O}$ vapor, $10 \%$ $\mathrm{CO}, 10 \% \mathrm{H}_{2}, 40 \% \mathrm{~N}_{2}$. The temperature of this second stream is usually between $900-1100{ }^{\circ} \mathrm{C}$ and is referred to as the furnace temperature. The solids are expected to flow in a narrow stream.

An example of the specifications of the reactor, the initial and boundary conditions is in Appendix E.

\subsection{Results of Simulation}

These simulations investigated two different operating conditions. During pyrolysis, char is introduced into the reactor with nitrogen only. Although Reactions II, IV and VI take place their effect is minimal and the dominant reaction is Reaction I which involves the reduction of sodium sulfate by carbon. Since carbon is present in excess it is not the limiting variable in determining sulfate reduction. Thus results from simulation of pyrolysis conditions illustrate the effects of sulfate concentration and furnace temperature on sulfate reduction. The sulfate reduction reaction is mildly endothermic and the heat of reaction does not induce noticeable changes in the temperature. 


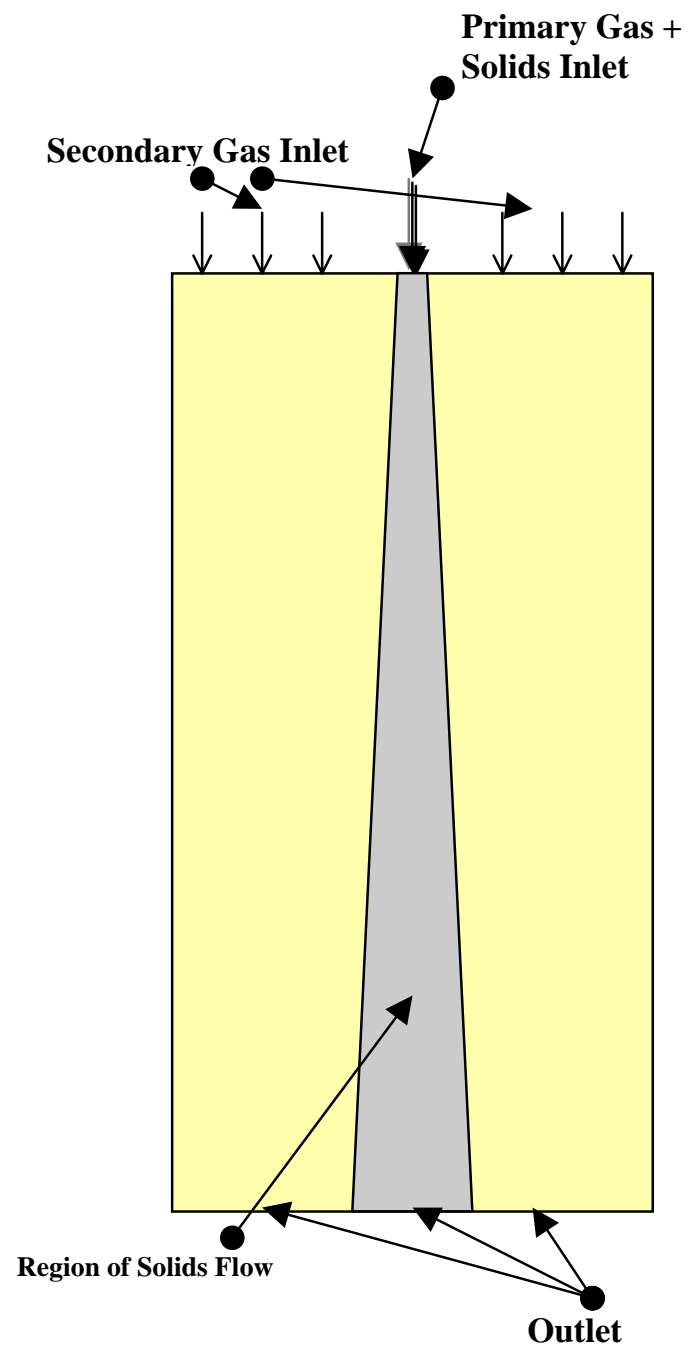

(b) LEFR as used in simulations.

Temperatures: $900-1100^{\circ} \mathrm{C}$.

Pressures: 16 psi.

Primary Gas Flow: $0.15 \mathrm{~L} / \mathrm{min}\left(\mathrm{N}_{2}\right.$ at $20^{\circ} \mathrm{C}$ and $\left.1 \mathrm{~atm}\right)$

Solids Feed Rate: $0.5-1.0 \mathrm{~g} / \mathrm{min}$ of particles.

Secondary Gas Flow: $20 \mathrm{~L} / \mathrm{min}\left(20^{\circ} \mathrm{C}\right.$ and $\left.1 \mathrm{~atm}\right)$

Figure 4-1. The laminar entrained flow reactor and experimental conditions.

$\mathrm{CO}_{2}, \mathrm{H}_{2} \mathrm{O}, \mathrm{H}_{2}$, and $\mathrm{CO}$ are introduced, in addition to $\mathrm{N}_{2}$, in the gas stream during gasification of black liquor char. All reactions except those involving oxygen occur during this operating condition. The dominant reactions are Reactions I, II and III, which involve 
sulfate reduction by carbon, gasification of carbon by carbon dioxide and water vapor. Carbon is no longer present in excess and is competitively consumed by sulfate, $\mathrm{CO}_{2}$ and $\mathrm{H}_{2} \mathrm{O}$. Hence, carbon becomes the limiting reactant during this stage. Reactions like the formation of $\mathrm{COS}, \mathrm{H}_{2} \mathrm{~S}$, and sodium vapor release (Reactions IV, V and VI) are very small relative to the rate of consumption of carbon according to Reactions I, II and III. Therefore, results from gasification illustrate the effect of competitive consumption of carbon on sulfate reduction.

Table 4-1. Conditions and Variables Studied.

\begin{tabular}{|c|c|}
\hline Pyrolysis & Gasification \\
\hline Temperatures $900-1100^{\circ} \mathrm{C}$ & Temperatures $900-1100^{\circ} \mathrm{C}$ \\
\hline \multicolumn{2}{|c|}{ Results } \\
\hline $\begin{array}{c}\text { Temperature Profiles of } \\
\text { Solids. }\end{array}$ & Temperature Profiles of Solids. \\
\hline Flow Profiles & Flow Profiles \\
\hline Variation with temperature & Variation with temperature \\
\hline
\end{tabular}

\subsubsection{Pyrolysis}

Results from pyrolysis of black liquor char, whose composition is listed in Table 3-1, are illustrated below. The simulation was done for furnace temperatures (temperature of the secondary gas feed) between $900-1100^{\circ} \mathrm{C}$. Simulation results confirm results published results regarding the behavior of different schemes for sulfate reduction by carbon [7]. While Cameron-Grace equation under-predicts the reduction of sulfate, it is reported in literature that the equation matches experimental data when multiplied by a factor 11.6 [7]. Results from our simulations support this observation.

Figures 4-2a, 4-2b and 4-2c illustrate the results from pyrolysis of black liquor char over the temperature range $900-1100^{\circ} \mathrm{C}$. Cameron-Grace equation is employed for the sulfate reduction reaction. 


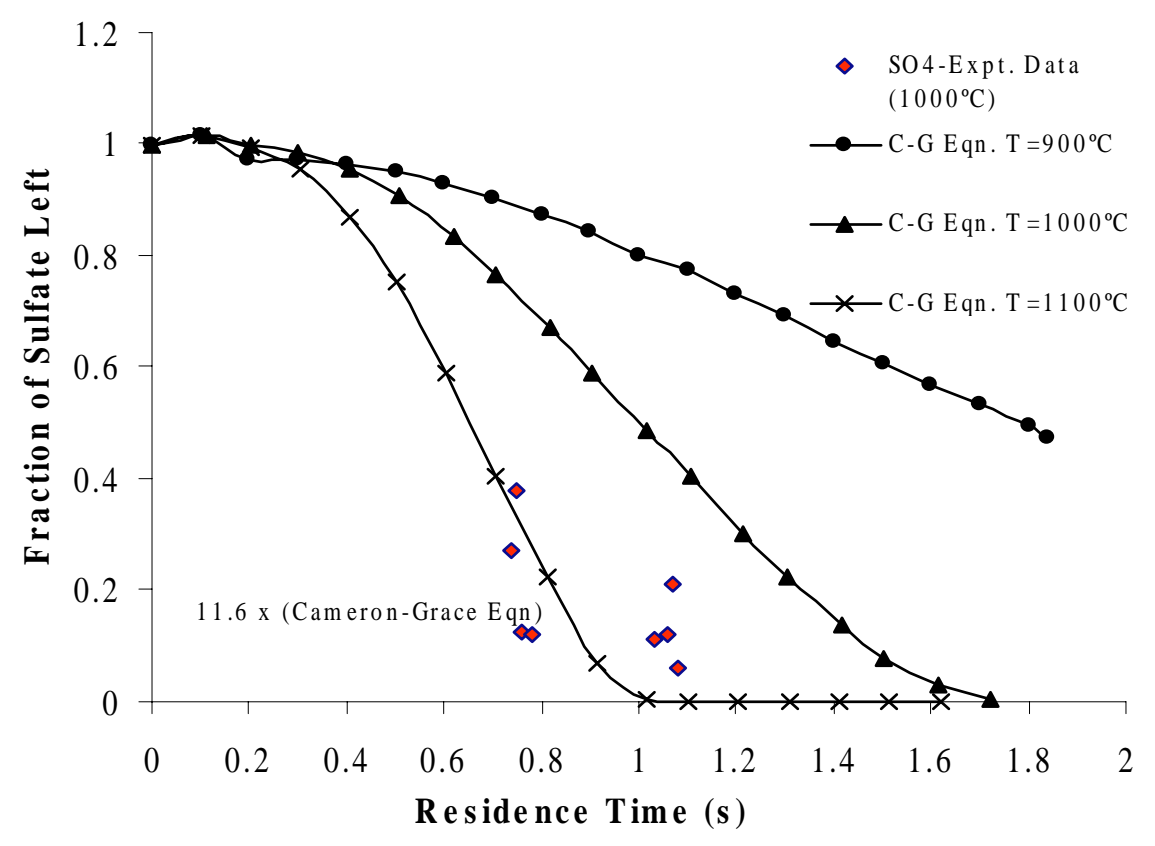

Figure 4-2a. Sulfate flow during pyrolysis of black liquor char (C-G Eqn.).

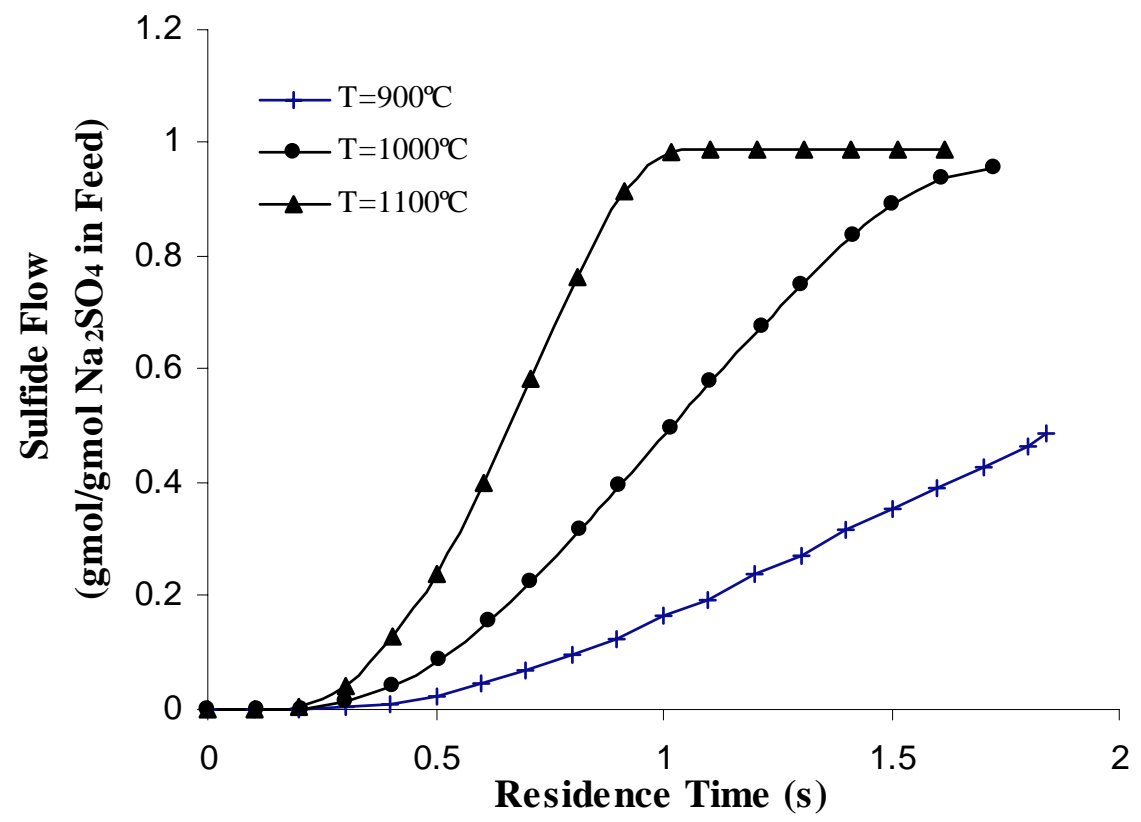

Figure 4-2b. Sulfide flow during pyrolysis of black liquor char (C-G Eqn.). 


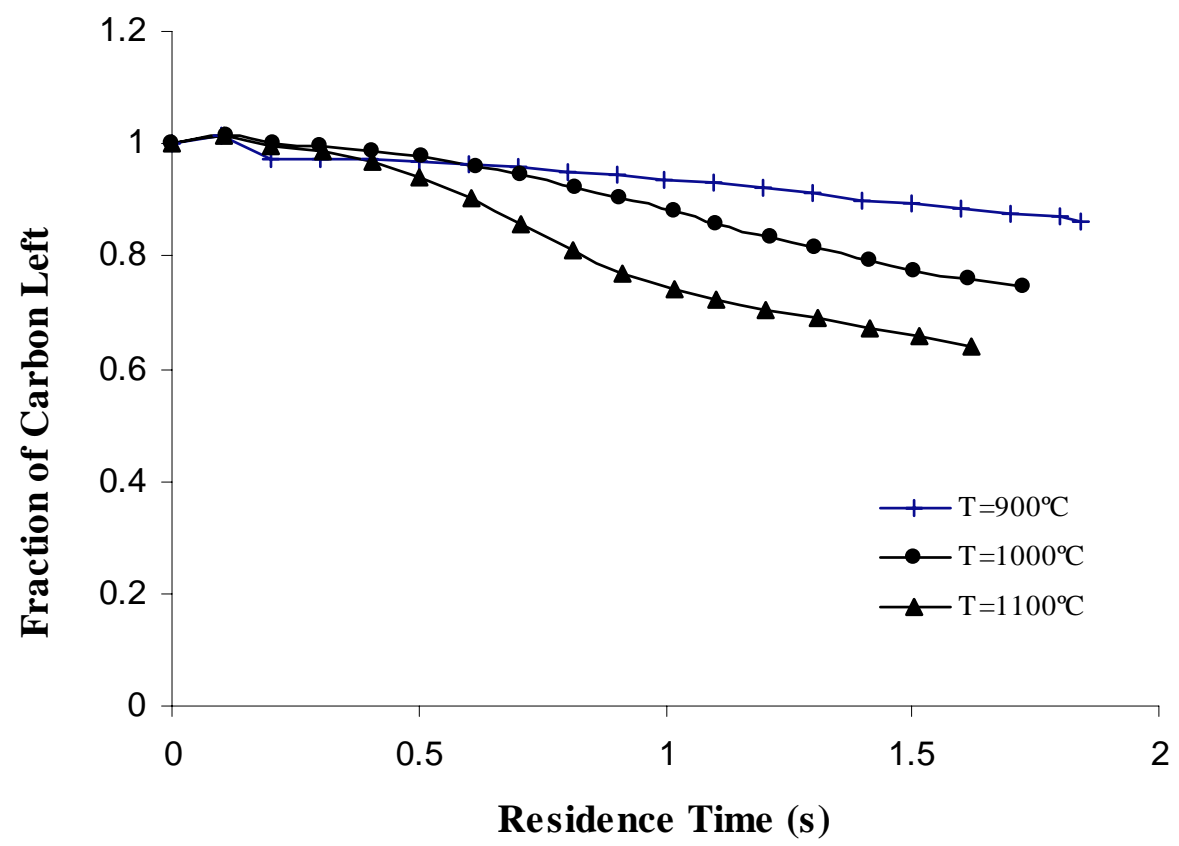

\section{Figure 4-2c. Carbon flow during pyrolysis of black liquor char (C-G eqn. for sulfate reduction).}

The two equations for sulfate reduction, Cameron-Grace and Wåg equations [6,7], show different sensitivities to temperature. The Cameron-Grace equation [6] is relatively more sensitive to temperature due to its higher activation energy.

Figures 4-3a through c show the results of pyrolysis of black liquor char between 900 and $1100^{\circ} \mathrm{C}$ using $\mathrm{W} a \mathrm{~g}$ rate equation for sulfate reduction reaction. It can be seen that the Wåg equation for sulfate reduction matches experimental results better than the CameronGrace equation. 


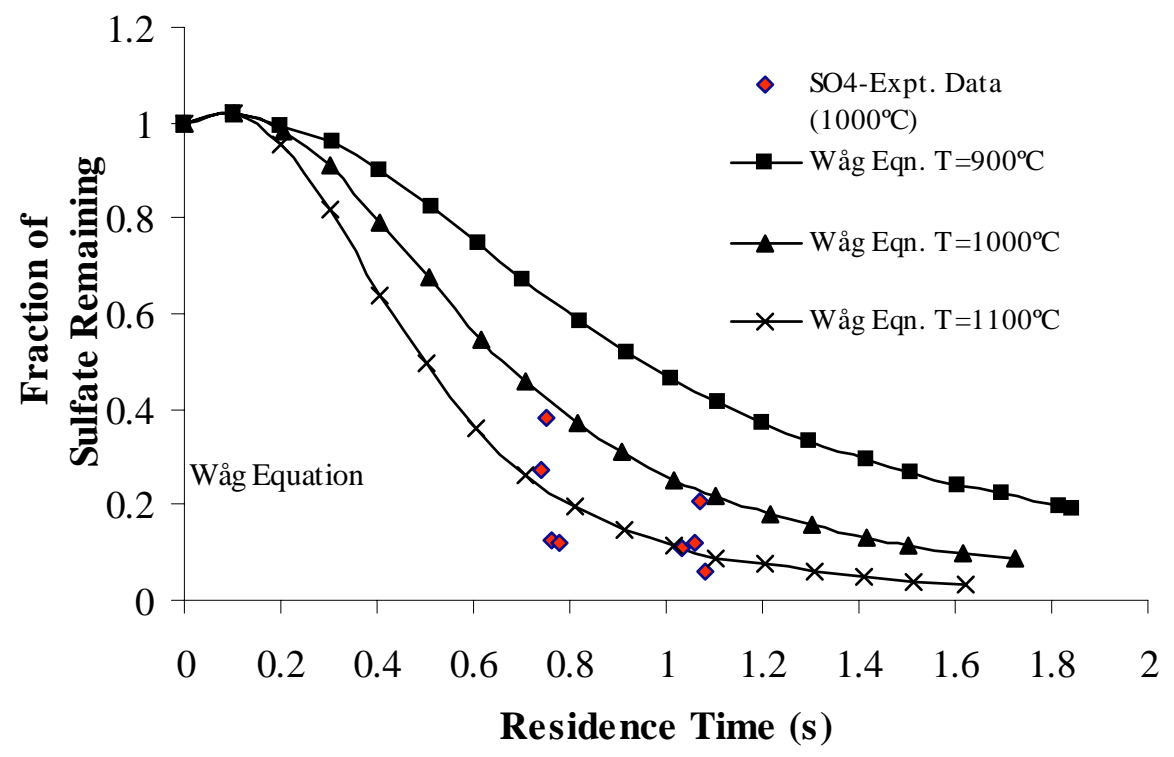

Figure 4-3a. Sulfate flow during pyrolysis of black liquor char (Wåg Eqn.).

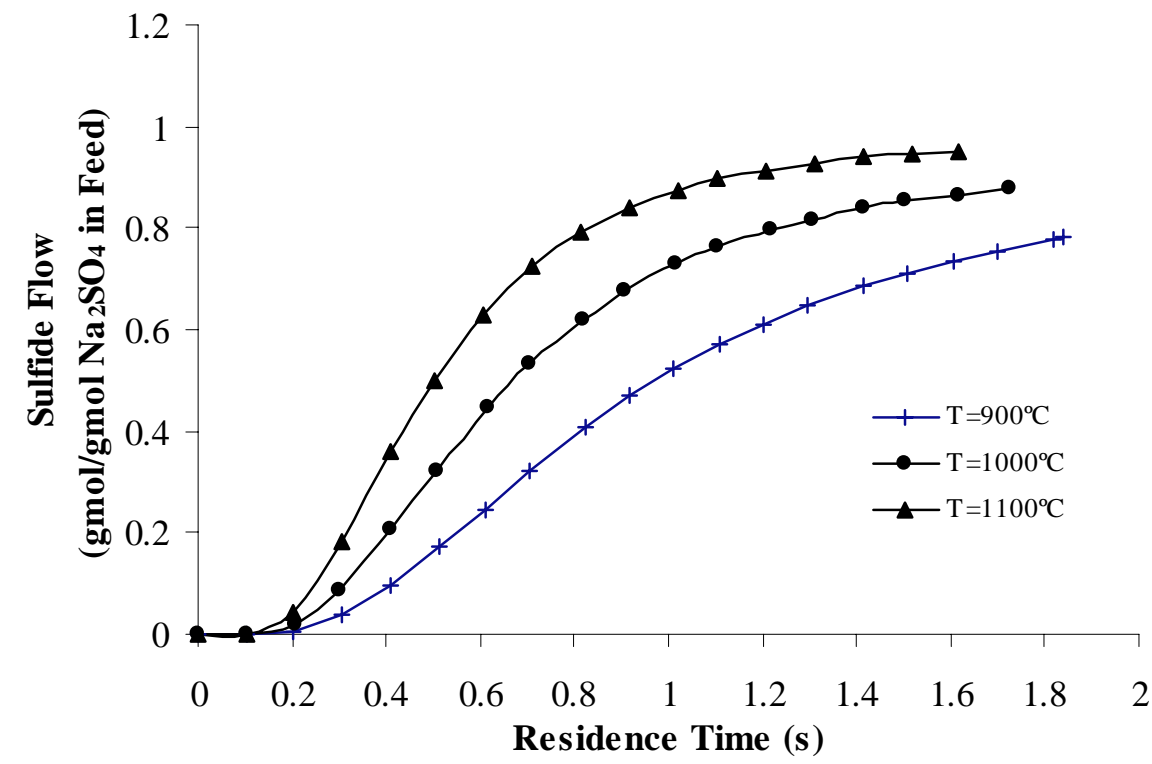

Figure 4-3b. Sulfide flow during pyrolysis of black liquor char (Wåg Eqn.). 


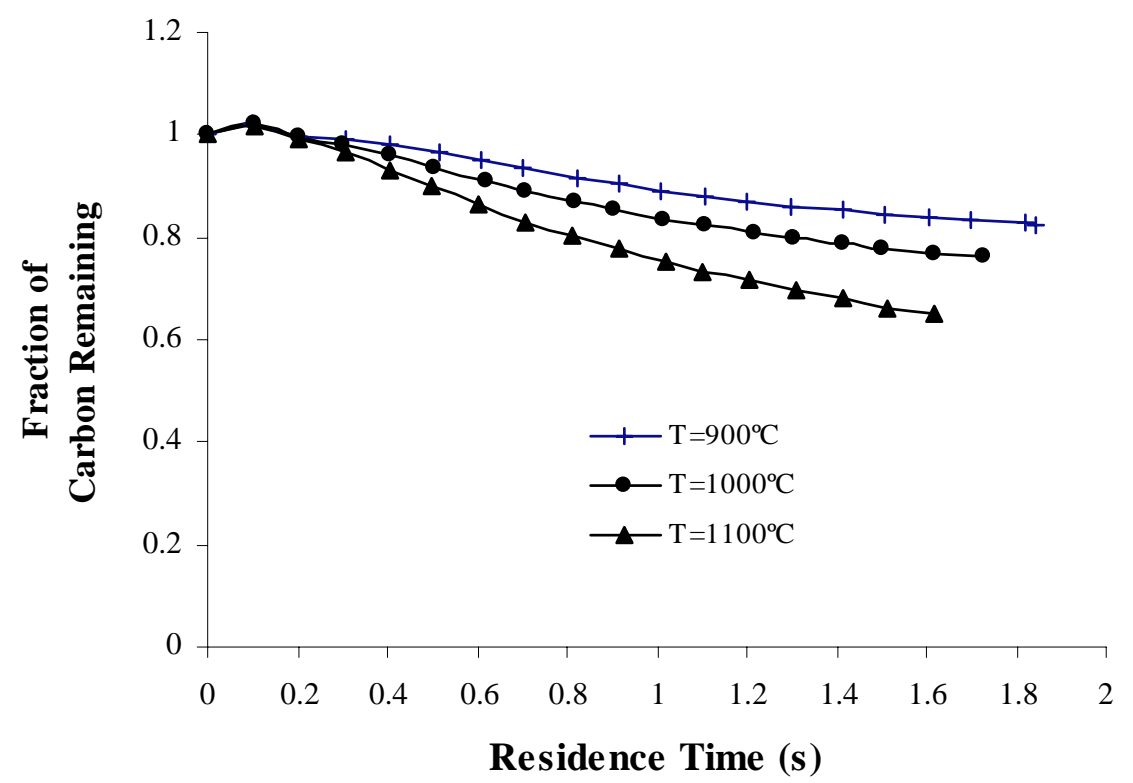

\section{Figure 4-3c. Carbon flow during pyrolysis of black liquor char (Wåg Eqn. for sulfate reduction).}

Results for pyrolysis using the modified Cameron-Grace equation (Figure 4-2a), show wider variation in the rate of sulfate reduction in terms of temperature. With increasing temperatures, the slope of the curves increase sharply. At $1100^{\circ} \mathrm{C}$ the slop is so steep that the sulfate is completely reduced to zero at a residence time of $1 \mathrm{~s}$. The Wag equation, however, does not show this rapid variation in the slope. The Langmuir-Hinshelwood type of dependence on sulfate concentration in Cameron-Grace equation results in the order of sulfate dependence varying between zero and one. The Wag equation, however, shows an order of 1.4 on sulfate concentration. Perhaps the dual effects of temperatures and reaction order are both responsible for the differences in the sulfate reduction curves.

\subsubsection{Gasification}

Results from gasification of black liquor char, with the composition of solid and gas feeds as shown in Table 3-1 and 3-2, are illustrated in Figures 4-4 and 4-5. The results are 
from simulations at $900-1100^{\circ} \mathrm{C}$ with Cameron-Grace [7] and Wåg equations [6] being used for sulfate reduction, respectively. As seen in the figures, sulfate reduction is less compared to experimental data, while the gasification of carbon matched experimental results very well. These modeling results also match the modeling results from literature [7].

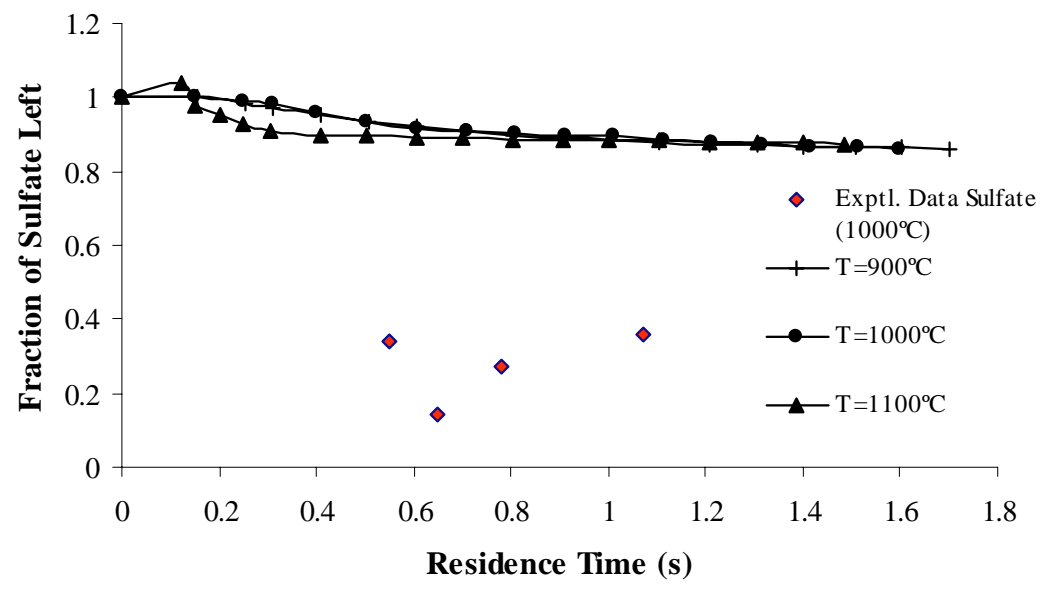

Figure 4-4a. Sulfate flow during gasification of black liquor char at $900-1100^{\circ} \mathrm{C}$ (C-G Eqn.).

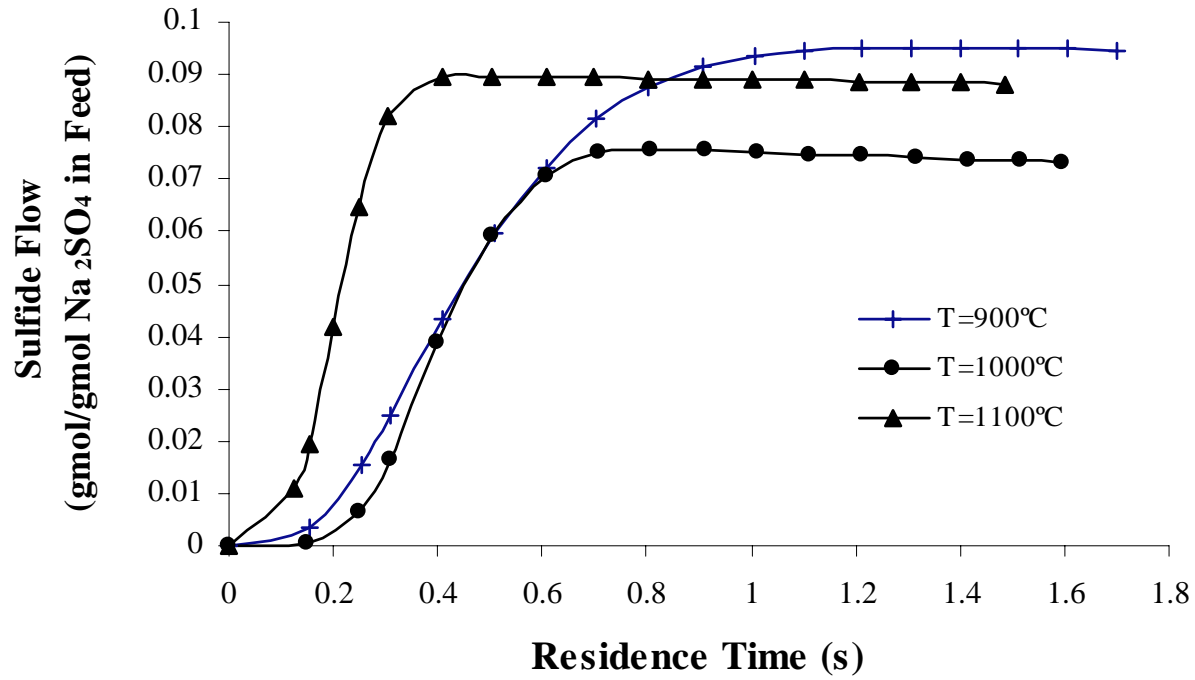

Figure 4-4b. Sulfide flow during gasification of black liquor char at $900-1100^{\circ} \mathrm{C}$ (C-G Eqn.). 


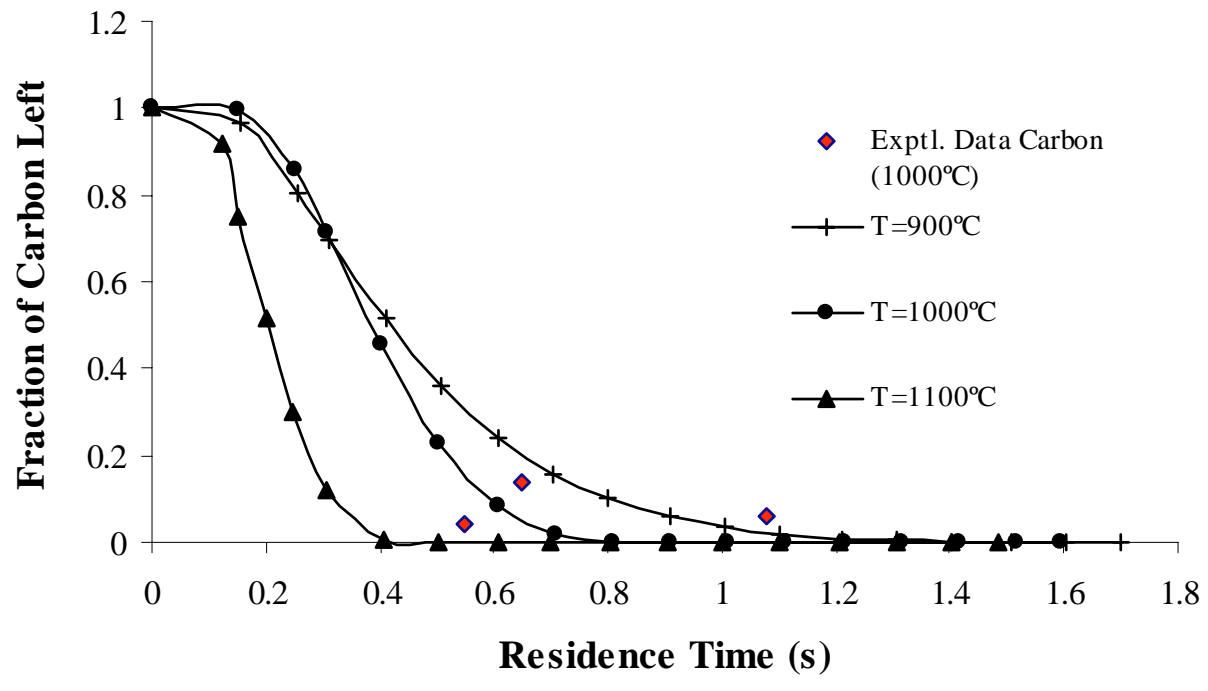

Figure 4-4c. Carbon flow during gasification of black liquor char at $900-1100^{\circ} \mathrm{C}$ (C-G Eqn. For Sulfate Reduction).

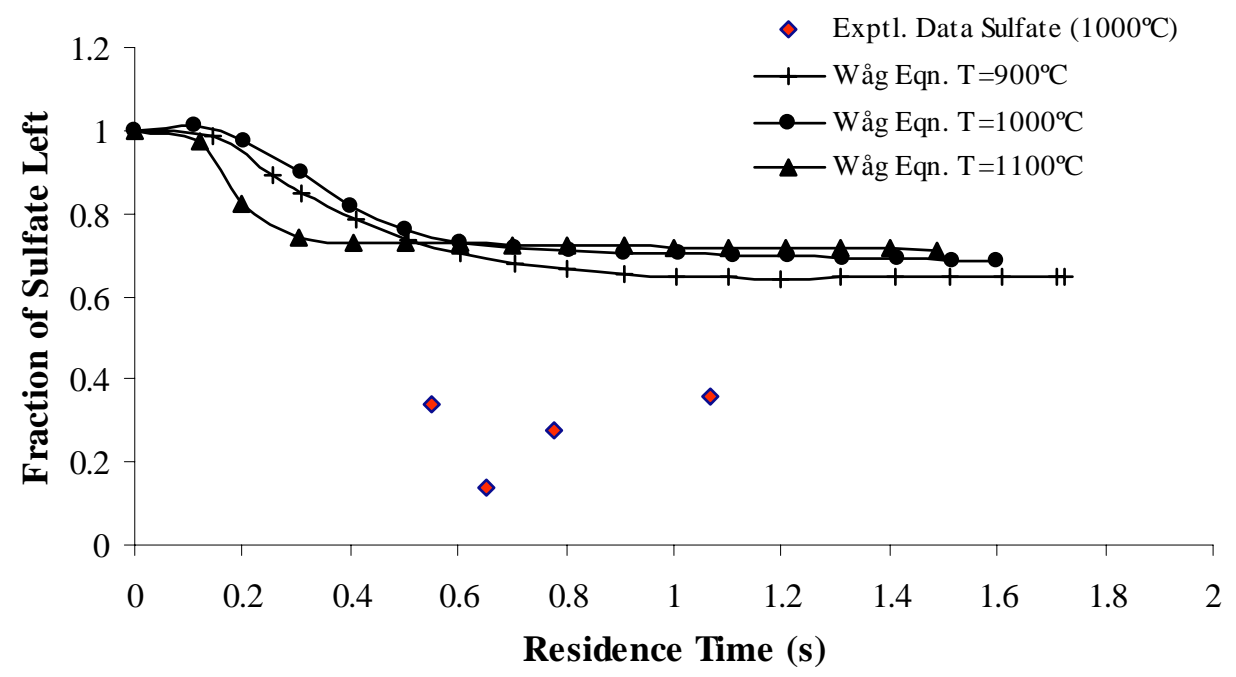

Figure 4-5a. Sulfate flow during gasification of black liquor char at $900-1100^{\circ} \mathrm{C}$ (Wåg Eqn.). 


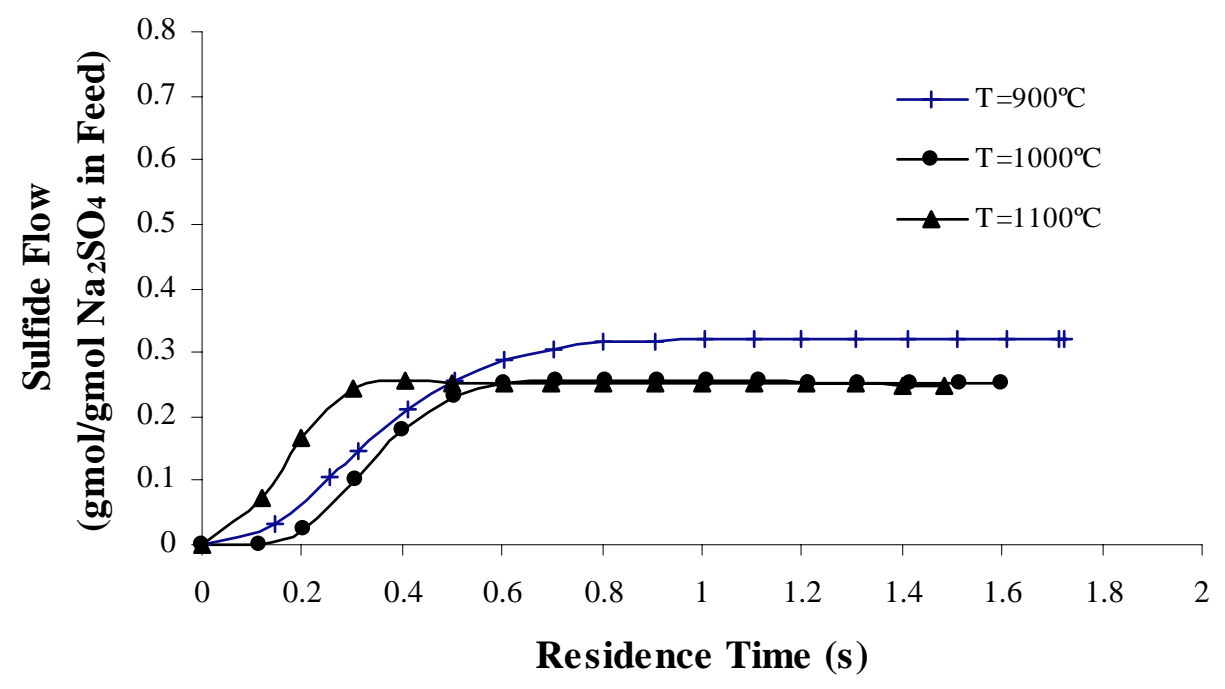

Figure 4-5b. Sulfide flow during gasification of black liquor char at $900-1100^{\circ} \mathrm{C}$ (Wåg Eqn.).

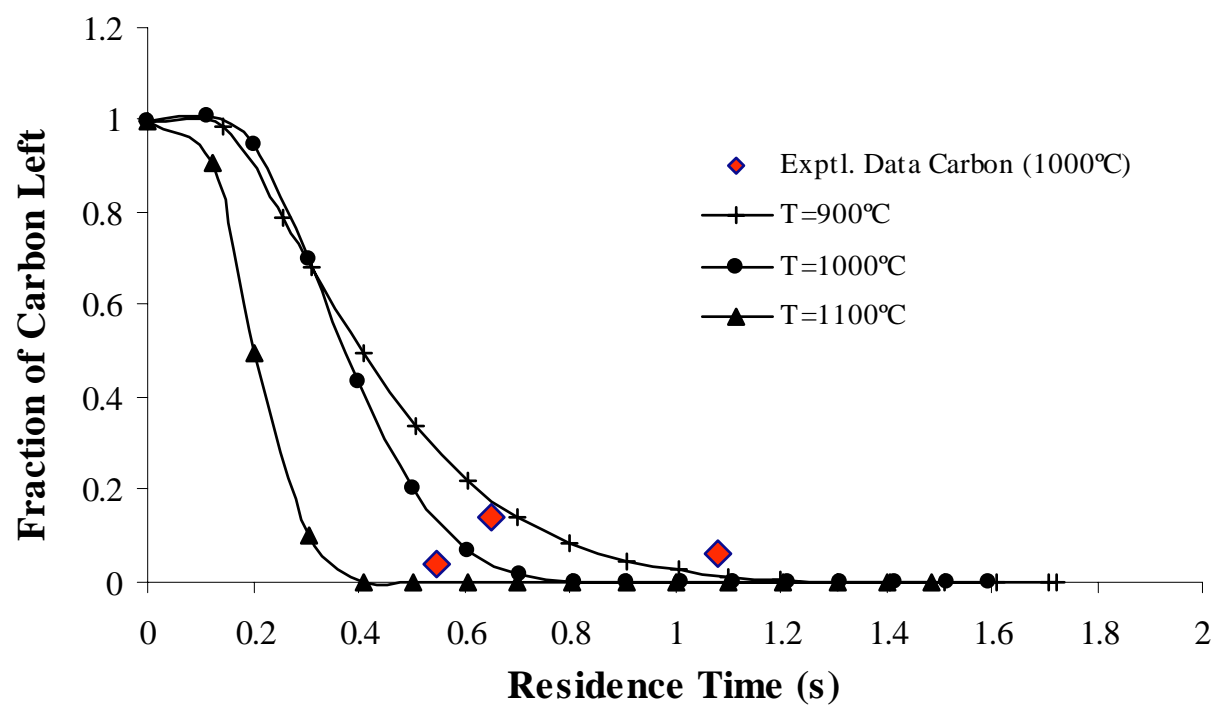

Figure 4-5c. Carbon flow during gasification of black liquor char at $900-1100^{\circ} \mathrm{C}$ (Wåg Eqn. for sulfate reduction). 


\subsubsection{Flow Profiles}

The flow profiles at 900 and $1100^{\circ} \mathrm{C}$ are presented below. As seen in solids volume fraction profiles, solids flux profiles and the velocity profiles, (Figures 4-6, 4-7 and 4-8), the solids tend to flow in a central region and there is little radial spreading. The solids velocity is higher than the velocity of gas because of the downward flow. This feature, flow in a narrow central region, and little variation in the velocity of solids permits the calculation of residence time of solids very easily. Residence time of solids is calculated by the simple formula,

$$
\tau=\mathrm{L} / \mathrm{V}_{\mathrm{avg}}
$$

Temperature profiles are shown in Figures 4-9 and 4-10. Figure 4-9 illustrates radial temperature gradients near the solids inlet and Figure 4-10 shows the rate at which the solids temperature rises with height of the reactor. The rate of heating of the particles affects the relative rates of sulfate reduction and carbon gasification. 

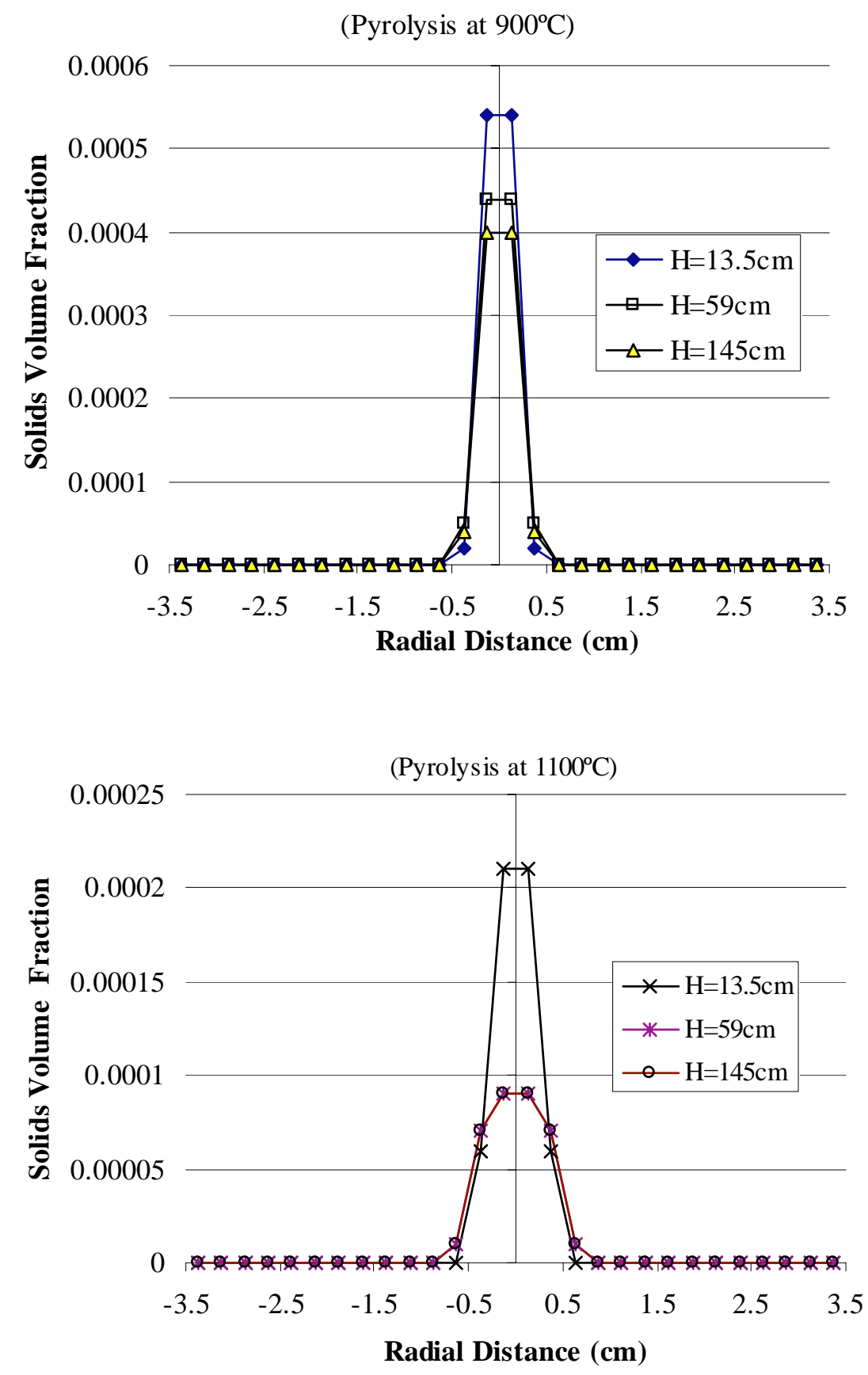

Figure 4-6 Solids volume fraction profiles. 

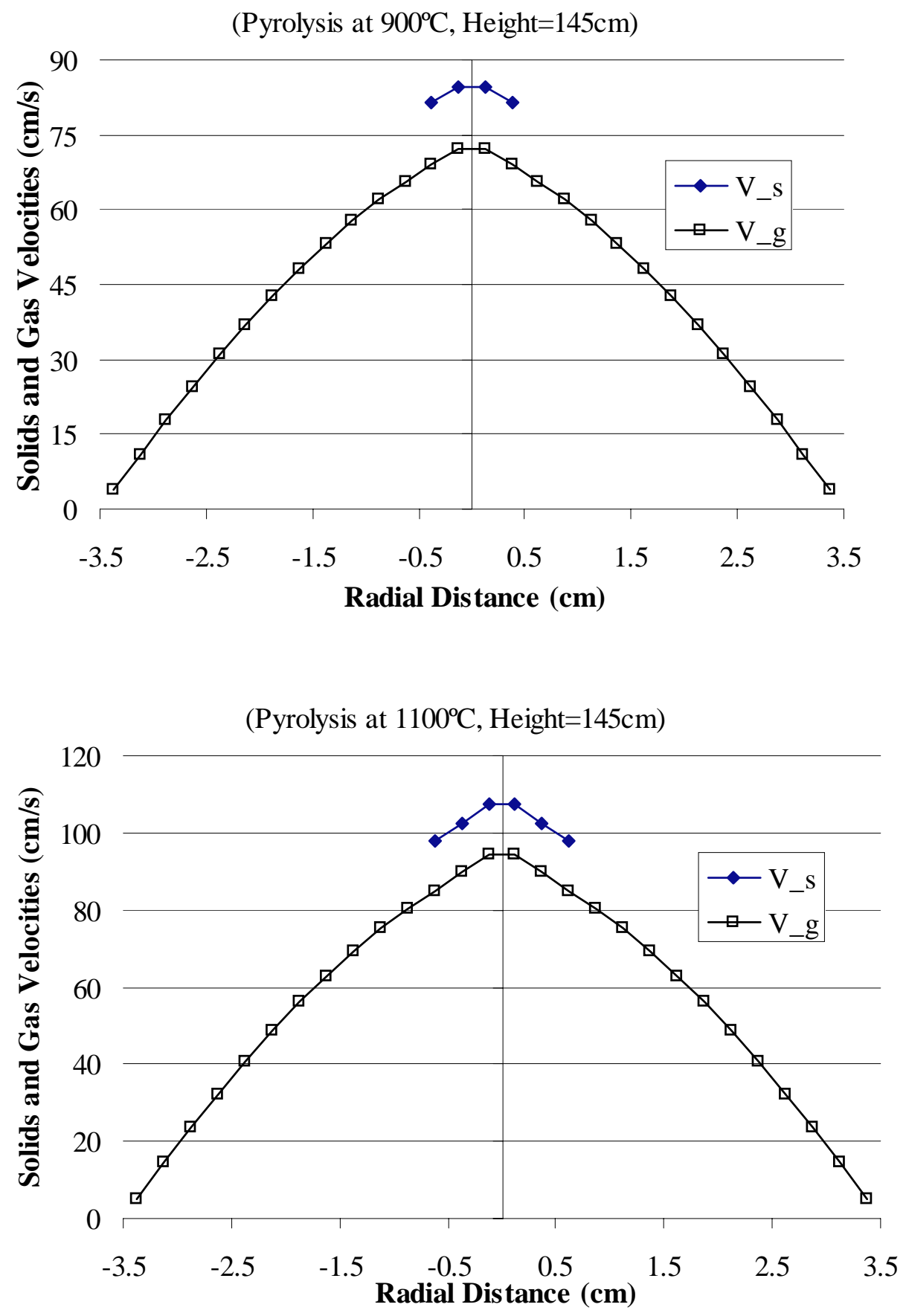

Figure 4-7. Gas and solids velocity profiles. 


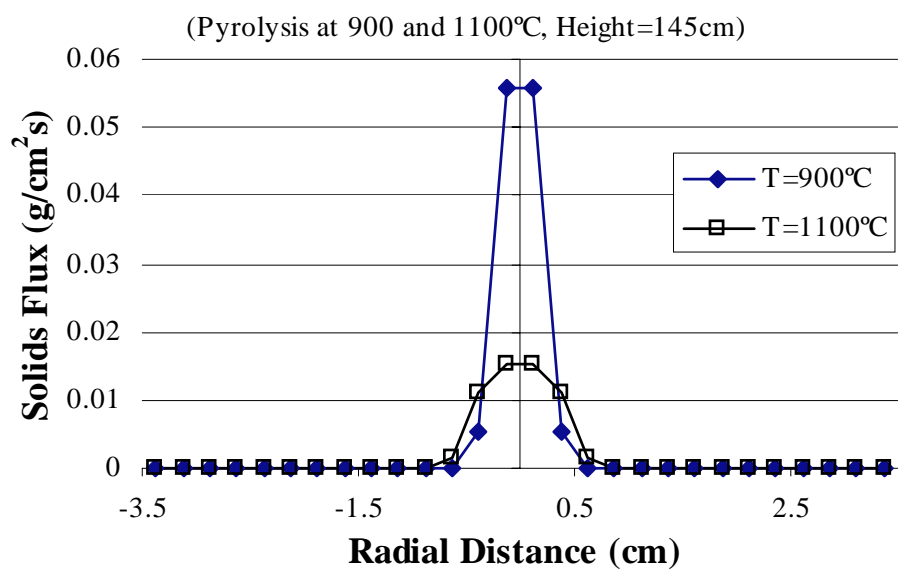

Figure 4-8. Solids flux profiles.
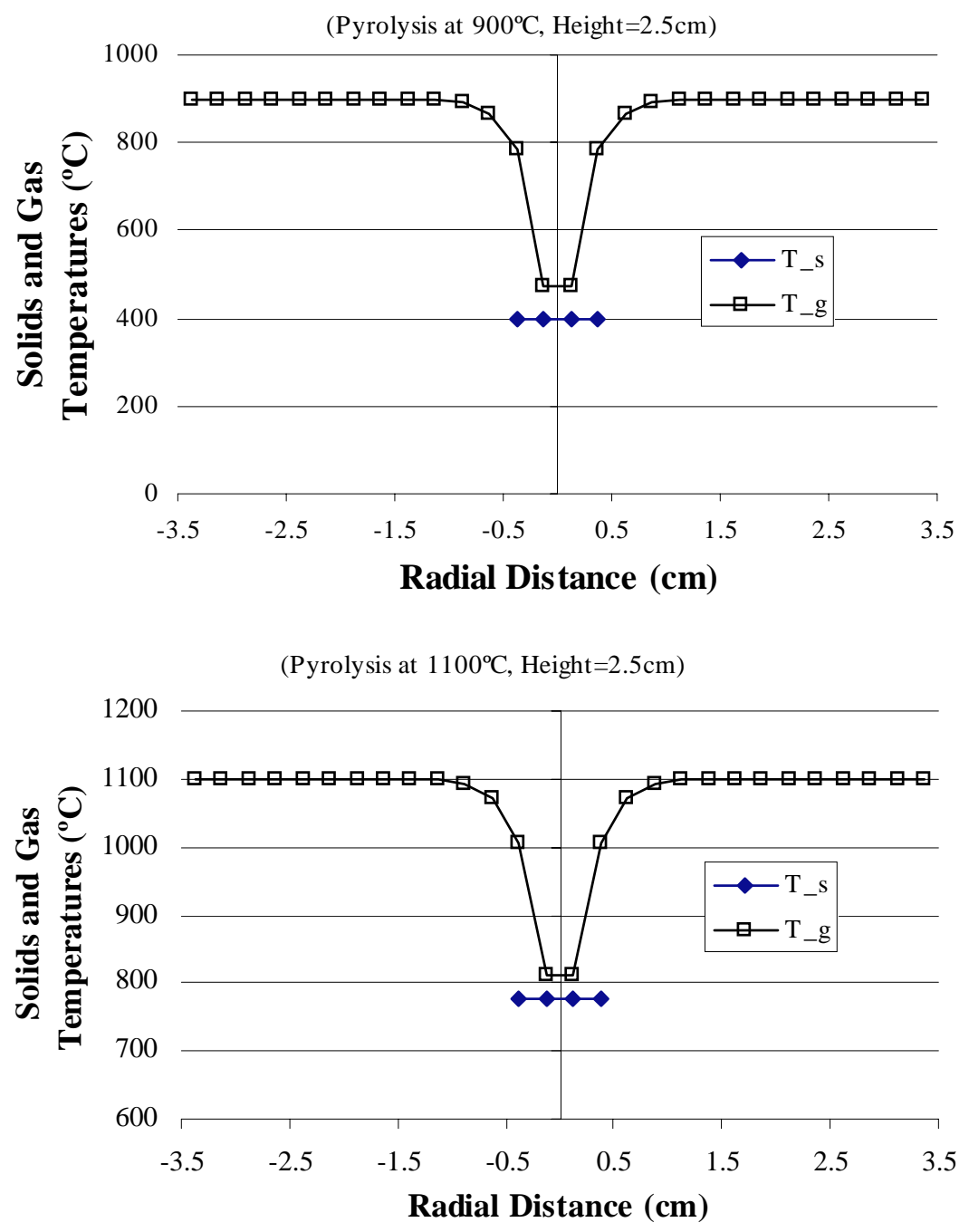

Figure 4-9. Radial temperature profiles. 


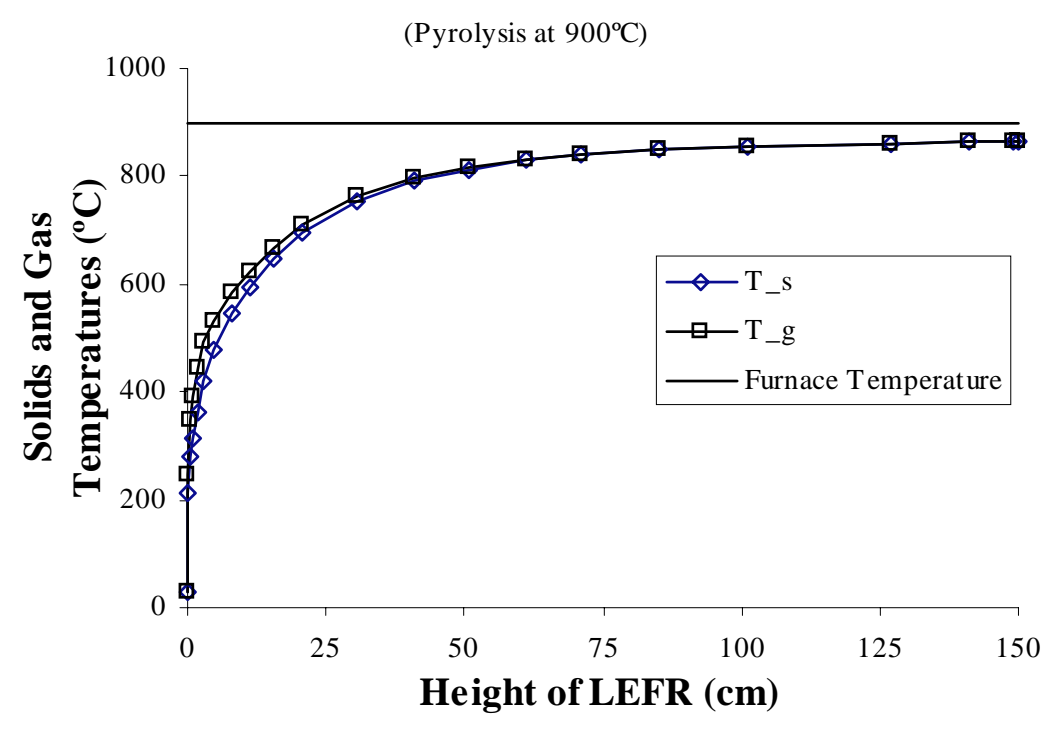

Figure 4-10. Axial temperature profiles.

\subsection{Limitations}

Agreement with published experimental results for pyrolysis of black liquor char particles shows that the reaction kinetics incorporated into MFIX work well. It can be noted that the two equations for sulfate reduction behave differently.

On some plots, it can be seen that the curves for the fraction of the species tends to shoot above one, for small values of residence time. It is thought that the high heat fluxes and strong concentration gradients near the inlet contribute to formation of these "spikes" in the solution. It was observed that the simulations required very small grid sizes and small time steps $\left(\sim 10^{-5} \mathrm{~s}\right)$ to ensure convergence to a sensible solution. The formation of large "spikes" tends to produce meaningless results.

\subsubsection{Changing Diameter of Particles}

Black liquor solids undergo substantial expansion and reduction in the devolatilization and char burning stages, respectively. The char burning stage involves shrinking particles due to loss of mass from the solid phase to the gas phase. The diameter reduces by a factor of six 
[29]. MFIX cannot handle changing particle sizes, thus posing a limitation on the simulations. The results show reasonable agreement in spite of this limitation. As an approximation, the routines containing the code for chemical reactions also compute an "apparent" diameter, which is used only for calculations of reaction rates, using the empirical equation for diameter change from literature [29]. The results subsequent to this change are not presented here.

\subsubsection{Heats of Reaction}

Heats of reaction for the various reactions were not included due to constraints posed by the time taken for each simulation trial and increased difficulty in obtaining convergence. The results presented contain no generation/loss of heat due to chemical reactions. It is reasonable to assume that heats of reaction would have an effect on the temperature profiles and thus the rates of various reactions.

\subsubsection{Limited Results}

The results presented here show the chemical reactions with respect to one dimension, time. The main aim of this research is to incorporate the models for chemical kinetics into MFIX and compare the results from both other experimental data and other modeling data. Published experimental data, show the species concentration or the extent of reaction with respect to residence time only. Thus, further comparisons of results with respect to dimensions in space cannot be made at this time. Upgrading the chemical kinetics to include the heats of reaction, approximations for the changing sizes, and the incorporation of other stages would yield us a comprehensive model, which might be used to study both the fluid dynamics and reaction kinetics with respect to space and time dimensions. 


\subsection{Extending the Model and Future Work}

These simulations model the char burning stage of chemical recovery only. Integration of a complete hydrodynamic model with the rate equations for chemical reactions represents an important step in modeling black liquor chemical recovery. This model permits the simulations of different reactor configurations and is easily extensible and scalable.

Models for other stages like devolatilization are to be found in literature [29]. However, these models are not dynamic and represent little more than mass balance and heat of reaction calculations based on experimental evidence. Translation of these static calculations into rate equations, to approximate a dynamic model, remains to be done.

The inability of MFIX to handle changing particle sizes remains a bottleneck for all these models. Extending the model to cover all the stages of black liquor process is the goal towards which future work needs to be directed.

The rate equations for chemical reactions are based on experimental evidence gathered by different researchers and are a combination of empirical and semi-empirical equations to explain various phenomena (e.g., calculation of change in diameter is explicit from the reaction rate equations and is done with empirical equations). This provides the ground for developing and testing integrated equations which incorporate all changes in terms of chemical reaction rate equation and testing the efficacy of such equations. 


\section{CHAPTER 5}

\section{CONCLUSIONS}

- Acomprehensive CFD model for solving mass, momentum and energy transport equations during black liquor char burning has been developed here.

- The model was found to match experimental data very well.

- Pyrolysis of black liquor char in the presence of $\mathrm{N}_{2}$, gasification by $\mathrm{CO}_{2}$ and $\mathrm{H}_{2} \mathrm{O}$ and combustion in the presence of $\mathrm{O}_{2}$ in addition to $\mathrm{CO}_{2}$ and $\mathrm{H}_{2} \mathrm{O}$ in a Laminar Entrained Flow Reactor were simulated. Results from simulation of pyrolysis of black liquor char matched experimental data for sulfate reduction at $1000^{\circ} \mathrm{C}$. These results also showed that the rate expression from Wag et al. was better in predicting sulfate reduction than the expression from Cameron and Grace.

- Simulation of gasification conditions under-predicted sulfate reduction, which was in line with published modeling results. Results from simulation matched the experimental data for carbon consumption at $1000^{\circ} \mathrm{C}$, indicating the validity of rate equations proposed by $\mathrm{Li}$ et al., for carbon gasification.

- Heats of reaction were not incorporated into the model. It was observed that the temperature of black liquor char particles was important in determining sulfate reduction.

- MFIX is not capable of handling changing particle sizes and hence the particle sizes remained constant during these simulations. 


\section{APPENDIX A}

\section{Diffusion and Mass Transfer Coefficients}

The definition of Sherwood Number is (for any species i) [30],

$$
\mathrm{N}_{\mathrm{SHi}}=\frac{\mathrm{k}_{\mathrm{gi}} \mathcal{D}_{\mathrm{i}}}{\mathrm{d}_{\mathrm{p}}}
$$

Thus, the mass transfer coefficient, $\mathrm{k}_{\mathrm{gi}}$, can be calculated from the above equation. Sherwood number is calculated by the following equation in MFIX routines [32].

$$
\mathrm{N}_{\mathrm{SHi}}=\left(7-10 \varepsilon_{\mathrm{s}}+5 \varepsilon_{\mathrm{s}}{ }^{2}\right)\left(1+0.7 \mathrm{Re}^{0.2} \mathrm{~N}_{\mathrm{SCi}}^{\frac{1}{3}}\right)+\left(1.3-2.4 \varepsilon_{\mathrm{s}}+1.2 \varepsilon_{\mathrm{s}}{ }^{2}\right) \mathrm{Re}^{0.7} \mathrm{~N}_{\mathrm{SCi}}^{\frac{1}{3}}
$$

$\mathrm{R}_{\mathrm{e}}$ is the Reynolds Number and $\mathrm{N}_{\mathrm{Sci}}$, the Schmidt Number is calculated by [30],

$$
\mathrm{N}_{\mathrm{SCi}}=\frac{v}{\mathcal{D}_{\mathrm{i}}}
$$

The diffusivity of component $\mathrm{i}$ in the gas is calculated from the Chapman-Enskog equation [27],

$$
\mathscr{D}_{\mathrm{i}}=\frac{0.001858 \mathrm{~T}_{\mathrm{s}}^{3 / 2} \mathrm{M}_{\mathrm{AB}}^{1 / 2}}{\mathrm{P} \sigma_{\mathrm{AB}}^{2} \Omega_{\mathrm{D}}}
$$

where,

$$
\mathrm{M}_{\mathrm{AB}}=\sqrt{\frac{1}{\mathrm{M}_{\mathrm{A}}}+\frac{1}{\mathrm{M}_{\mathrm{B}}}}
$$

and

$$
\sigma_{\mathrm{AB}}=\frac{\left(\sigma_{\mathrm{A}}+\sigma_{\mathrm{B}}\right)}{2}
$$


$\sigma_{\mathrm{A}}$, the characteristic length, can be estimated from the critical properties of the component as follows [30],

$$
\sigma_{\mathrm{A}}=0.8410 \mathrm{~V}_{\mathrm{C}}^{1 / 3}
$$

$\Omega_{\mathrm{D}}$, the collision integral is estimated by the use of Neufeldt's correlation, [27]

$$
\Omega_{\mathrm{D}}=\frac{\mathrm{A}}{\mathrm{T}^{\mathrm{B}}}+\frac{\mathrm{C}}{\mathrm{e}^{\mathrm{DT}^{\circ}}}+\frac{\mathrm{E}}{\mathrm{e}^{\mathrm{FT}^{\mathrm{o}}}}+\frac{\mathrm{G}}{\mathrm{e}^{\mathrm{HT}^{\circ}}}
$$

The temperature $\mathrm{T}^{\mathrm{o}}$ is given by,

$$
\mathrm{T}^{\mathrm{o}}=\frac{\mathrm{kT}_{\mathrm{gas}}}{\varepsilon_{\mathrm{AB}}}
$$

where,

$$
\varepsilon_{\mathrm{AB}}=\left(\varepsilon_{\mathrm{A}} \varepsilon_{\mathrm{B}}\right)^{1 / 2}
$$

The Lennard-Jones potential, $\varepsilon / k$ for any species can also be imputed from its critical properties, as shown below [30].

$$
\left(\frac{\varepsilon}{\mathrm{k}}\right)_{\mathrm{i}}=0.75 \mathrm{~T}_{\mathrm{Ci}}
$$




\section{APPENDIX B}

\section{Equilibrium/Film Concentrations of Gas Species}

The equilibrium concentrations of carbonyl sulfide and hydrogen sulfide are given by [29],

$$
[\mathrm{COS}]_{\mathrm{eq}}=\frac{\mathrm{P}_{\mathrm{COS}}}{\mathrm{RT}_{\text {gas }}}
$$

where,

$$
\mathrm{P}_{\mathrm{COS}}=\mathrm{P}_{\mathrm{CO} 2} \mathrm{e}^{\left(-16.28+\frac{11078}{\mathrm{~T}_{\mathrm{gas}}}\right)}
$$

and,

$$
\left[\mathrm{H}_{2} \mathrm{~S}\right]_{\mathrm{eq}}=\left[\mathrm{CO}_{2}\right]_{\mathrm{i}}\left[\mathrm{H}_{2} \mathrm{O}\right]_{\mathrm{i}} \mathrm{e}^{\left(-14.2+\frac{11351}{\mathrm{~T}_{\mathrm{gas}}}\right)}
$$

where,

$\left[\mathrm{CO}_{2}\right]_{\mathrm{i}}$ and $\left[\mathrm{H}_{2} \mathrm{O}\right]_{\mathrm{i}}$ are evaluated at the interface by,

$$
\left[\mathrm{CO}_{2}\right]_{\mathrm{i}}=\mathrm{P}_{\mathrm{CO} 2 \mathrm{i}} / \mathrm{RT}_{\text {gas }}
$$

and

$$
\left[\mathrm{H}_{2} \mathrm{O}\right]_{\mathrm{i}}=\mathrm{P}_{\mathrm{H} 2 \mathrm{O}} / \mathrm{RT}_{\text {gas }}
$$

The interface concentrations of various species can be found by, equating the mass transfer rate and kinetic reaction rate, which would be equal, when assumed to be at steady state. [29] Thus,

$$
P_{\text {interface }, \mathrm{i}}=\frac{\mathrm{k}_{\mathrm{g}, \mathrm{i}} \mathrm{P}_{\text {bulk }, \mathrm{i}} \mathrm{A}_{\mathrm{ext}}}{\left(\mathrm{A}_{\mathrm{ext}} \mathrm{k}_{\mathrm{g}, \mathrm{i}}+\mathrm{V}_{\mathrm{p}} \eta_{\mathrm{i}} \mathrm{k}_{\mathrm{r}, \mathrm{i}}\right)}
$$




\section{APPENDIX C}

\section{RRATES.F}

! vVVVVVVVVVVVVVVVVVVVVVVVVVVVVVVVVVVVVVVVVVVVVVVVVVVVVVVVVVVVVVVVVVVVVVC Module name: RRATES (IER)

Purpose: Calculate reaction rates for various reactions in cell ijk C

Author:

Date:

Reviewer:

Date:

Revision Number:

Purpose:

Author:

Reviewer:

Date: dd-mmm-yy c

Reviewer:

Date: dd-mmm-yy

Literature/Document References:

Variables referenced: MMAX, IJK, T_g, T_s1, D_p, X_g, X_s, EP_g, P_g, HOR_g, HOR_s

Variables modified: M, N, R_gp, R_sp, RoX_gc, RoX_sc, SUM_R_g, SUM_R_S

Local variables:partial pressures and concentrations

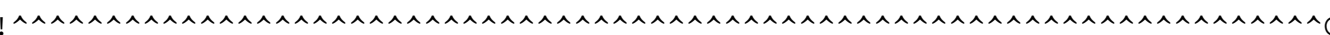

!

!

SUBROUTINE RRATES(IER)

!...Translated by Pacific-Sierra Research VAST-90 2.06G5 12:17:31 12/09/98

!....Switches: $-\mathrm{xf}$

! -----1

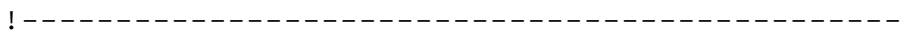

USE param

USE param1

USE parallel

USE fldvar

USE rXns

USE energy

USE geometry

USE run

USE indices

USE physprop

USE constant

USE funits

IMPLICIT NONE

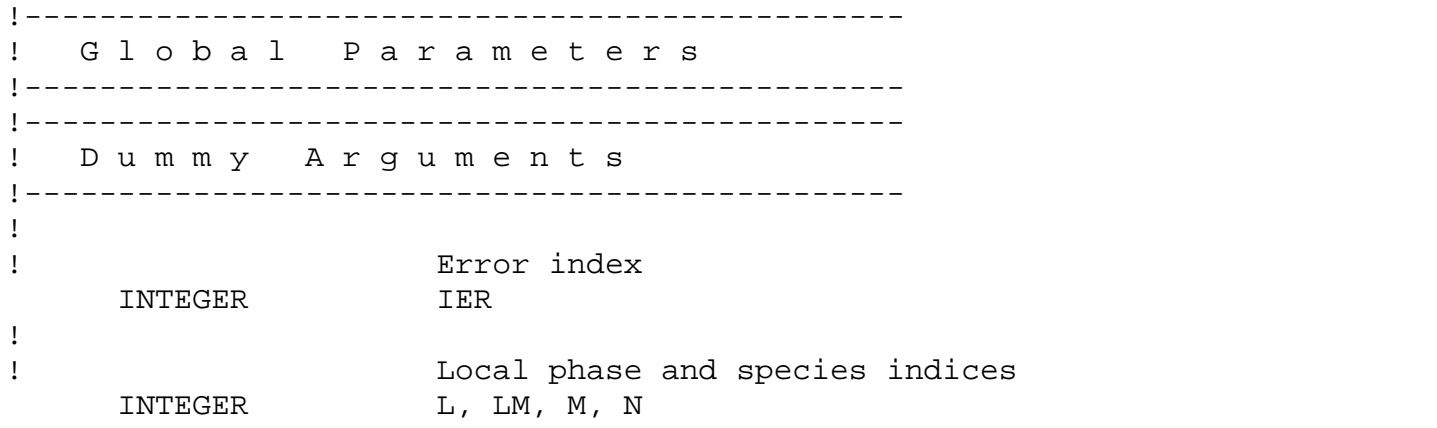




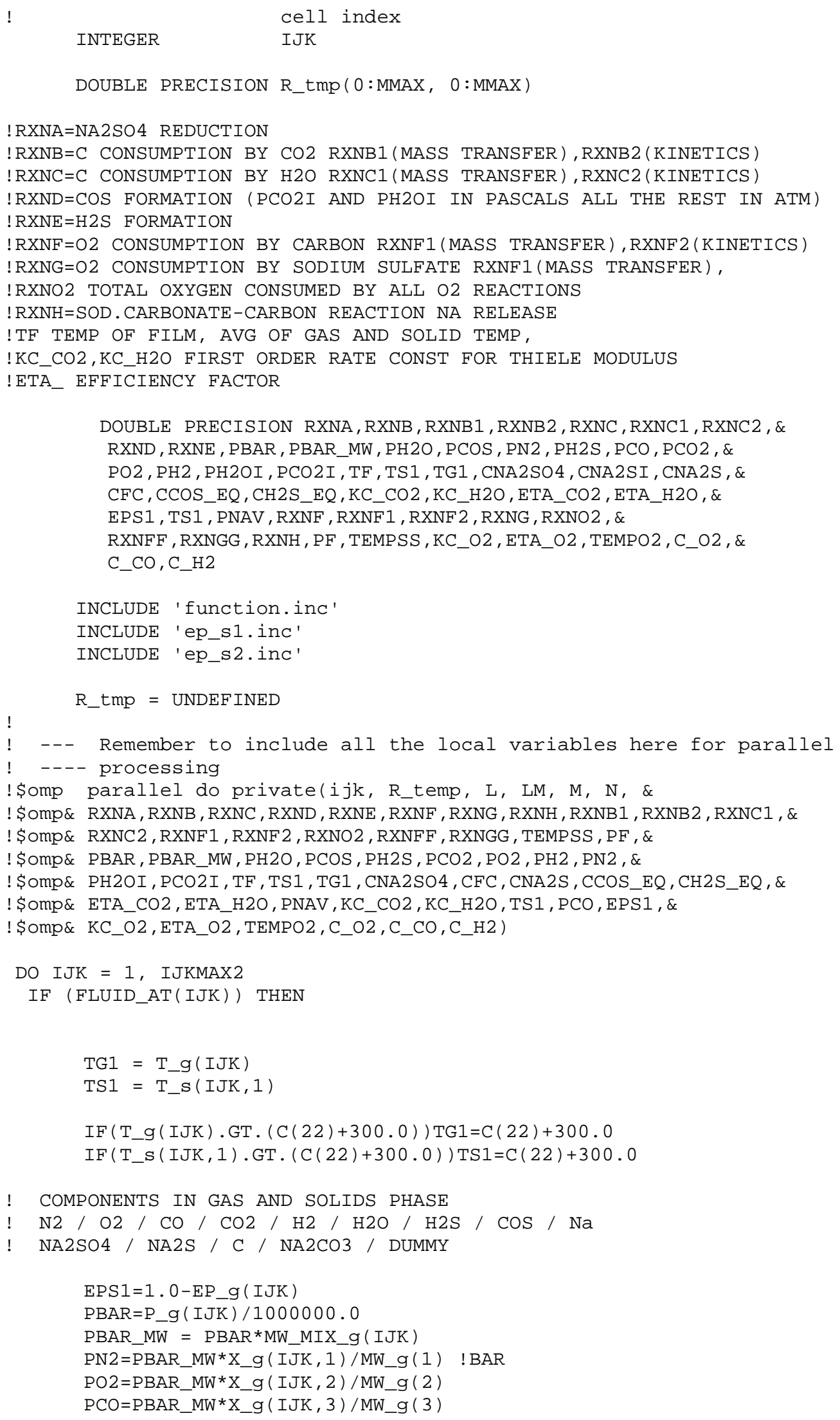




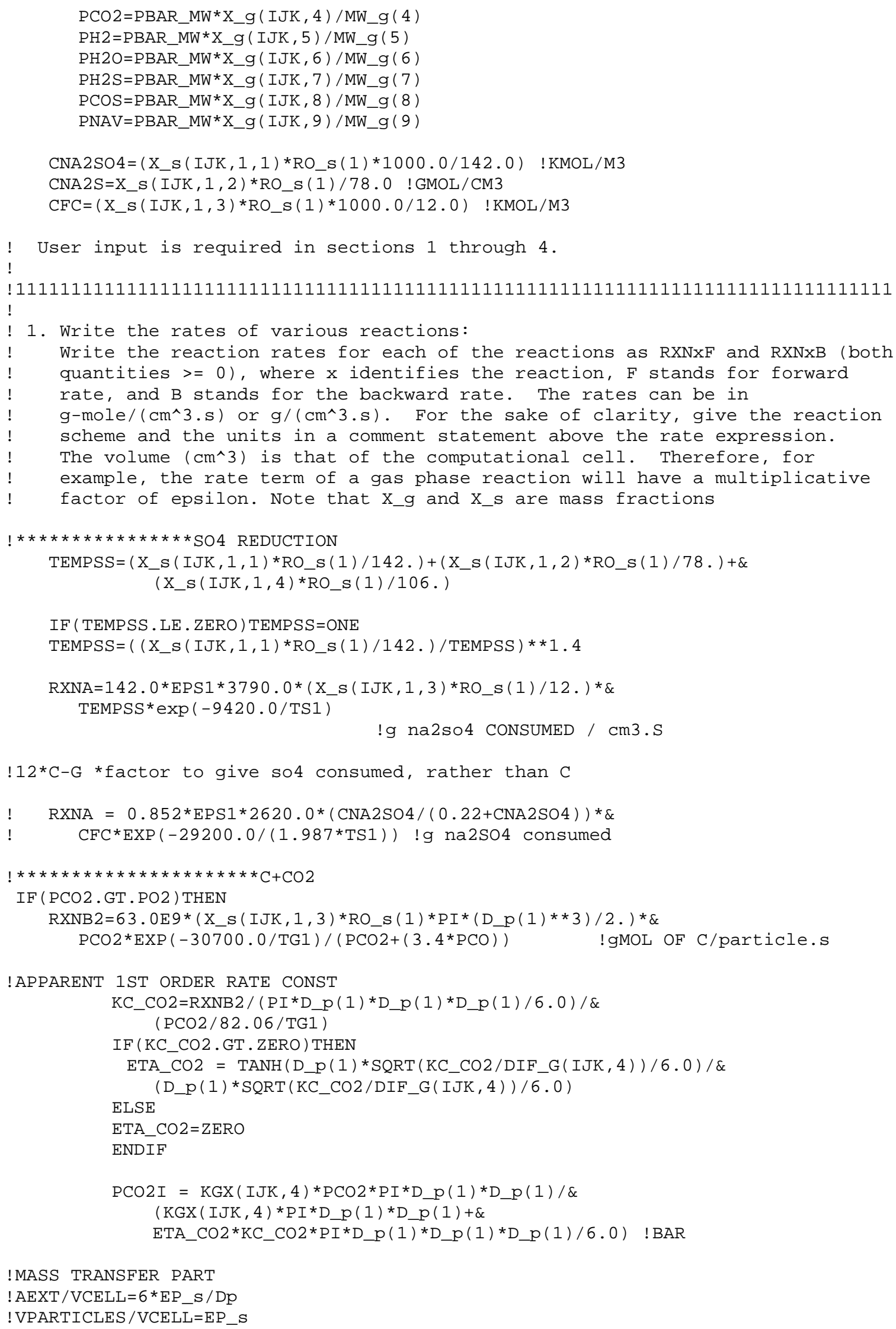

!MASS TRANSFER PART

! AEXT/VCELL $=6 * E P \_S / D P$

! VPARTICLES/VCELL=EP_S 


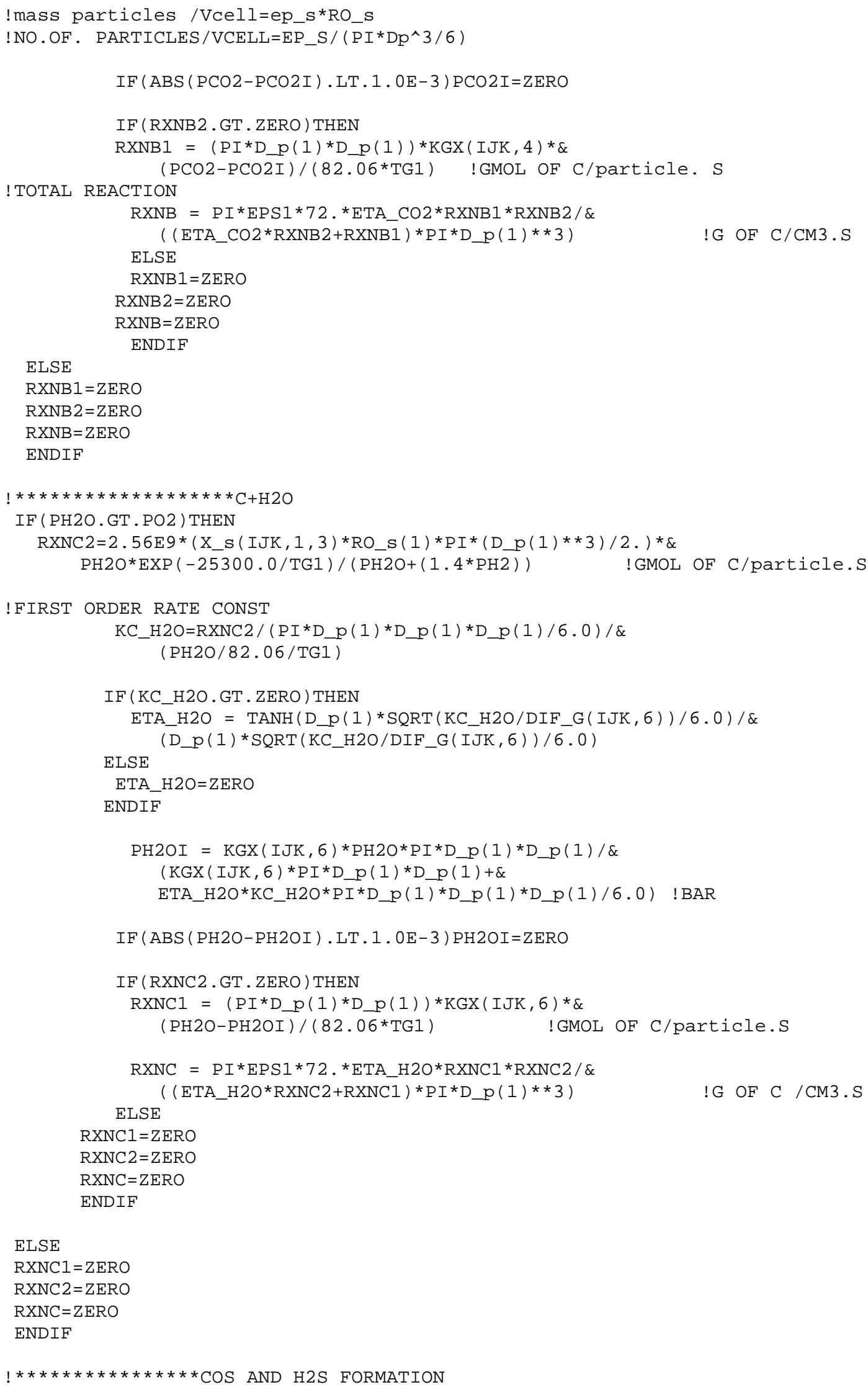




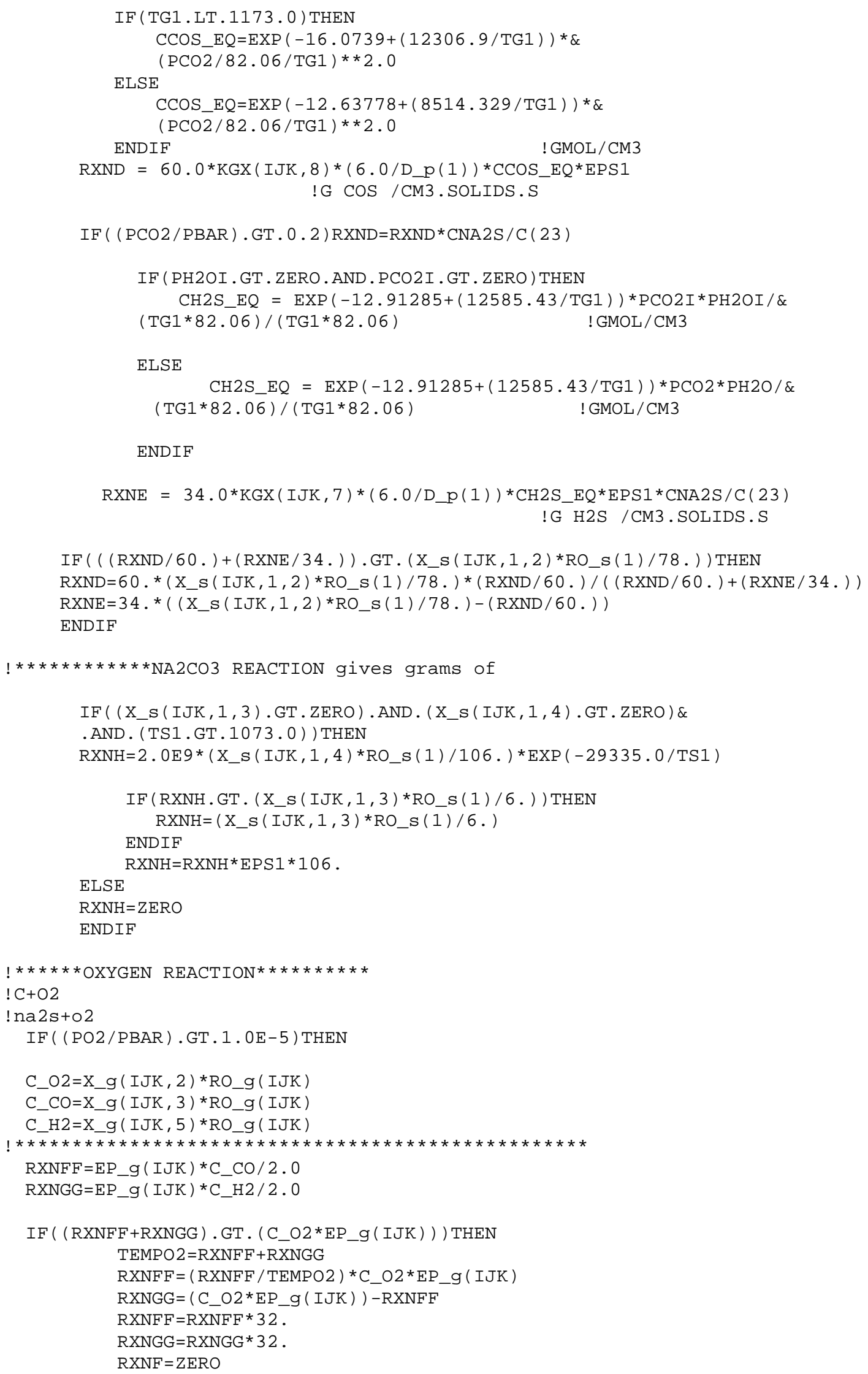

$\operatorname{IF}\left(((\mathrm{RXND} / 60)+.(\mathrm{RXNE} / 34).) . \mathrm{GT} .\left(X_{-} \mathrm{S}(\mathrm{IJK}, 1,2) * \mathrm{RO} \_\mathrm{s}(1) / 78.\right)\right) \mathrm{THEN}$ $\mathrm{RXND}=60 . *\left(X \_s(I J K, 1,2) * \mathrm{RO} \_s(1) / 78.\right) *(\mathrm{RXND} / 60) /.((\mathrm{RXND} / 60)+.(\mathrm{RXNE} / 34)$. $\mathrm{RXNE}=34 . *\left(\left(\mathrm{X} \_\mathrm{S}(\mathrm{IJK}, 1,2) * \mathrm{RO} \_\mathrm{s}(1) / 78.\right)-(\mathrm{RXND} / 60).\right)$ ENDIF 
RXNG $=$ ZERO

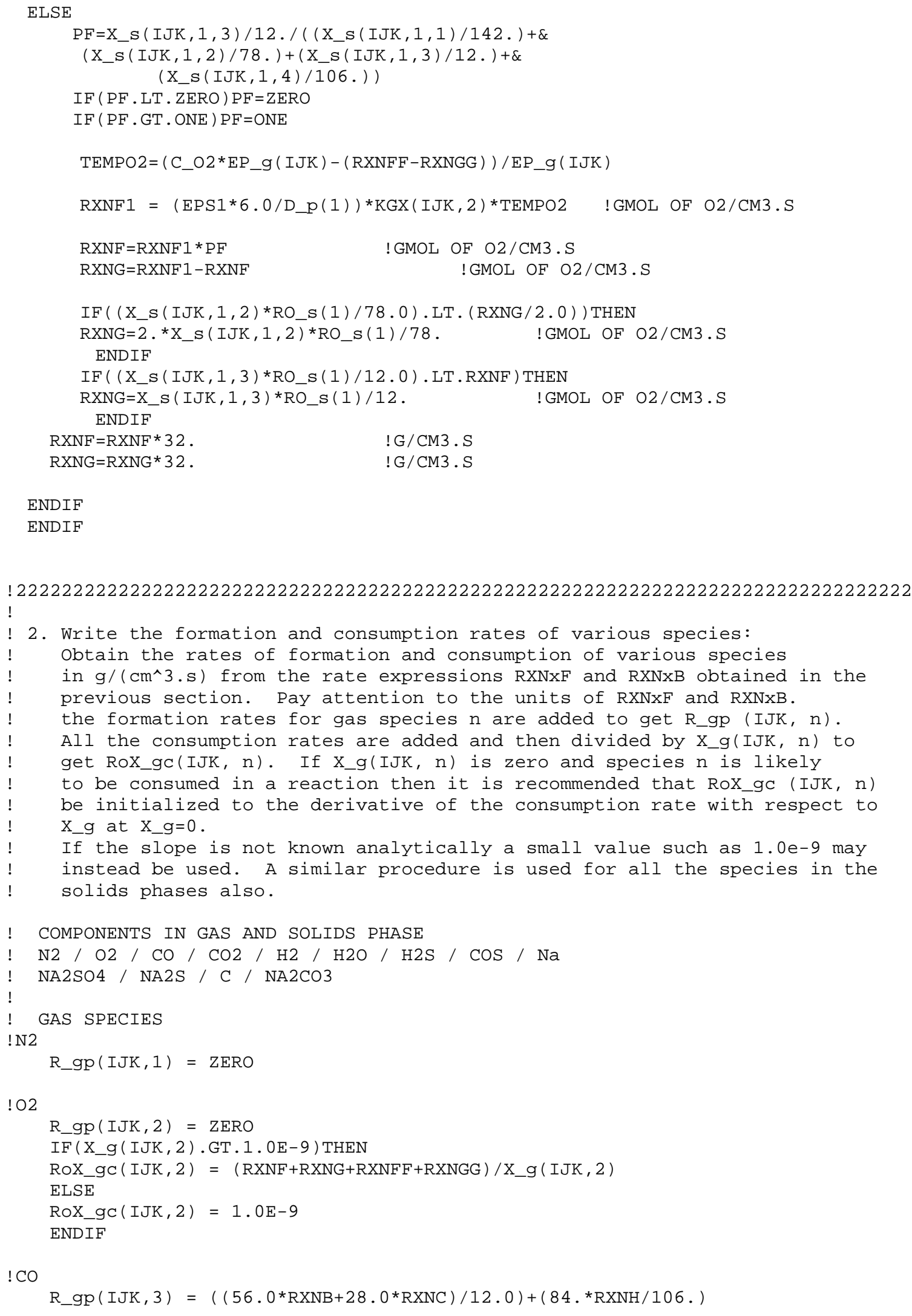


IF (X_g (IJK, 3).GT.1.0E-9) THEN

RoX_gc $(I J K, 3)=(\operatorname{RXNFF} * 28 . / 16.) / X \_g(I J K, 3)$

ELSE

ROX_gC $(I J K, 3)=1.0 E-9$

ENDIF

! $\mathrm{CO} 2$

R_gp $(I J K, 4)=\left(\mathrm{RXNA}^{2} 88.0 / 142.0\right)+(\mathrm{RXNF} * 44 . / 32)+.\left(\mathrm{RXNFF}^{*} 44 . / 16.\right)$

IF (X_g (IJK, 4).GT.1.0E-9) THEN

RoX_gc $(I J K, 4)=((R X N B * 44.0 / 12.0)+(R X N D * 88.0 / 60.0)+\varepsilon$

ELSE

$\left.\left(\mathrm{RXNE}^{*} 44.0 / 34.0\right)\right) / \mathrm{X} \_\mathrm{g}(\mathrm{IJK}, 4)$

RoX_gC $(I J K, 4)=1.0 E-9$

ENDIF

! H2

R_gp $(I J K, 5)=$ RXNC*2.0/12.0 ! GRAMS / CELL

IF (X_g (IJK, 5).GT.1.0E-7) THEN

RoX_gC $(I J K, 5)=(R X N G G * 2 . / 16.) / X \_g(I J K, 5)$

ELSE

RoX_gC $(I J K, 5)=1.0 \mathrm{E}-9$

ENDIF

! H2O

R_gp $(I J K, 6)=$ RXNGG*18./16. ! GRAMS/CELL

IF $\left(X \_g(I J K, 6) . G T .0 .0\right)$ THEN

RoX_gC $(I J K, 6)=\left(\left(R_{X N C} \star 18.0 / 12.0\right)+(R X N E \star 18.0 / 34.0)\right) / X \_g(I J K, 6)$

ELSE

RoX_gC $(I J K, 6)=1.0 \mathrm{E}-9$

ENDIF

! H2S

R_gp $(I J K, 7)=$ RXNE !GRAMS / CELL

! COS

R_gp $(I J K, 8)=$ RXND ! GRAMS / CELL

! $\mathrm{Na}$

R_gp $(I J K, 9)=$ RXNH$* 46 . / 106 . \quad$ ! GRAMS $/$ CELL

! SOLIDS SPECIES

! $\mathrm{Na} 2 \mathrm{SO} 4$

R_sp $(I J K, 1,1)=($ RXNG*142./64.) !GRAMS /CELL

IF (X_S (IJK, 1, 1).GT.1.0E-9) THEN

RoX_SC $(I J K, 1,1)=$ RXNA/X_S $(I J K, 1,1)$

ELSE

ROX_SC $(I J K, 1,1)=1.0 \mathrm{E}-9$

ENDIF

! NA2S

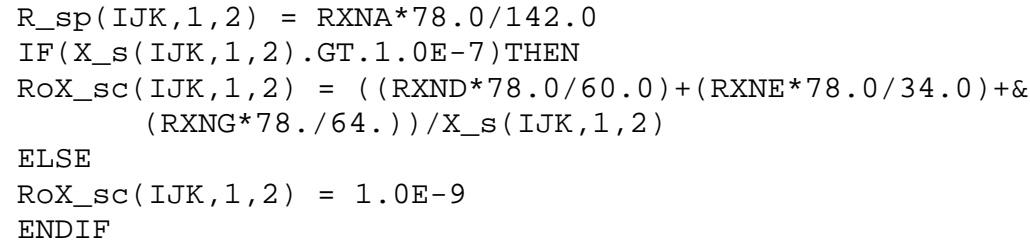

! C

R_sp $(I J K, 1,3)=0.0$

IF (X_S (IJK, 1, 3).GT.1.0E-9) THEN

RoX_SC $(I J K, 1,3)=(($ RXNA $24 . / 142)+.($ RXNB + RXNC $)+\varepsilon$

$\left.\left(\mathrm{RXNF}^{*} 12 . / 32.\right)+(\mathrm{RXNH} * 24 . / 106).\right) / \mathrm{X} \_\mathrm{s}(\mathrm{IJK}, 1,3)$ 


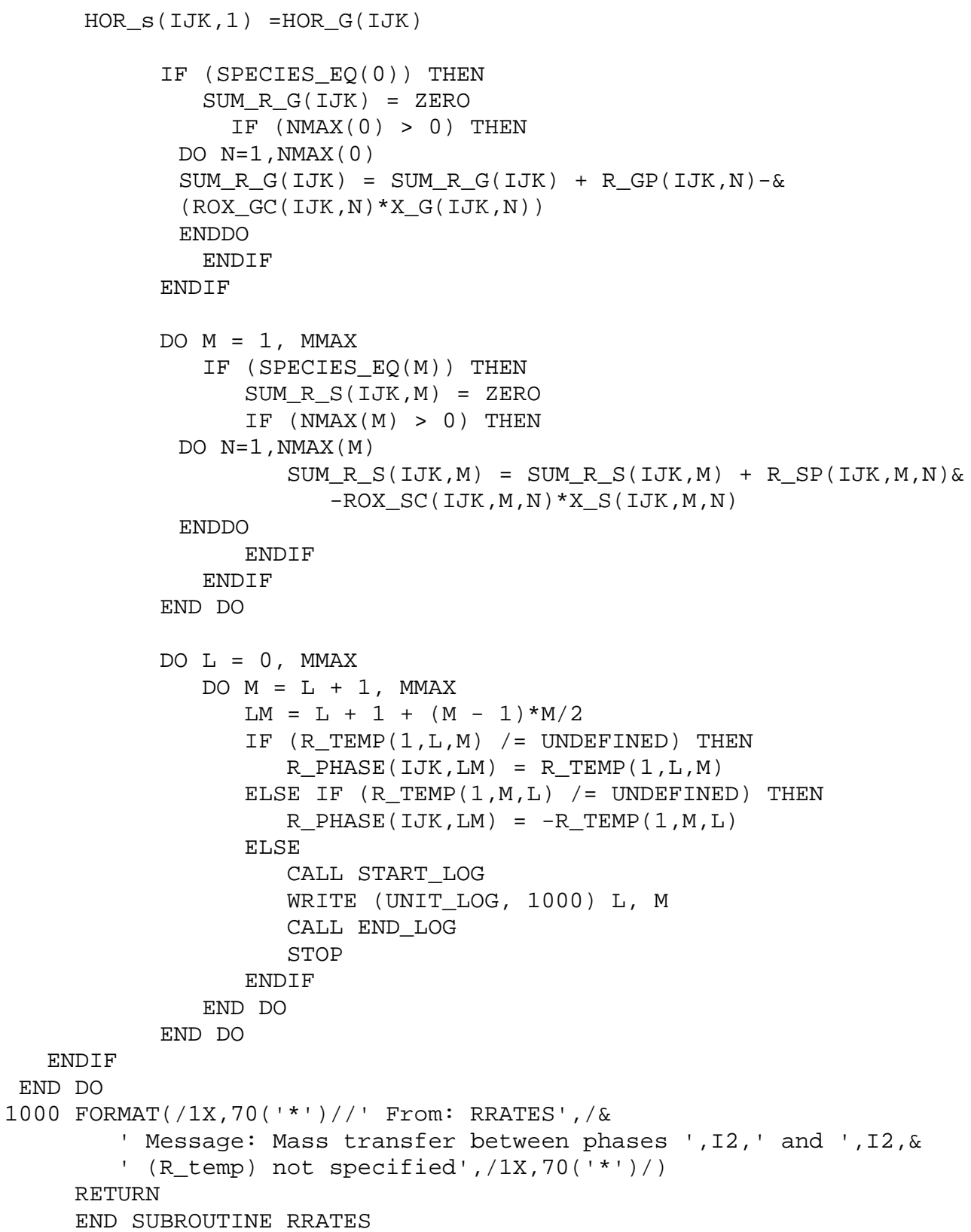




\section{APPENDIX D}

\section{CALC_DIF_G.F}

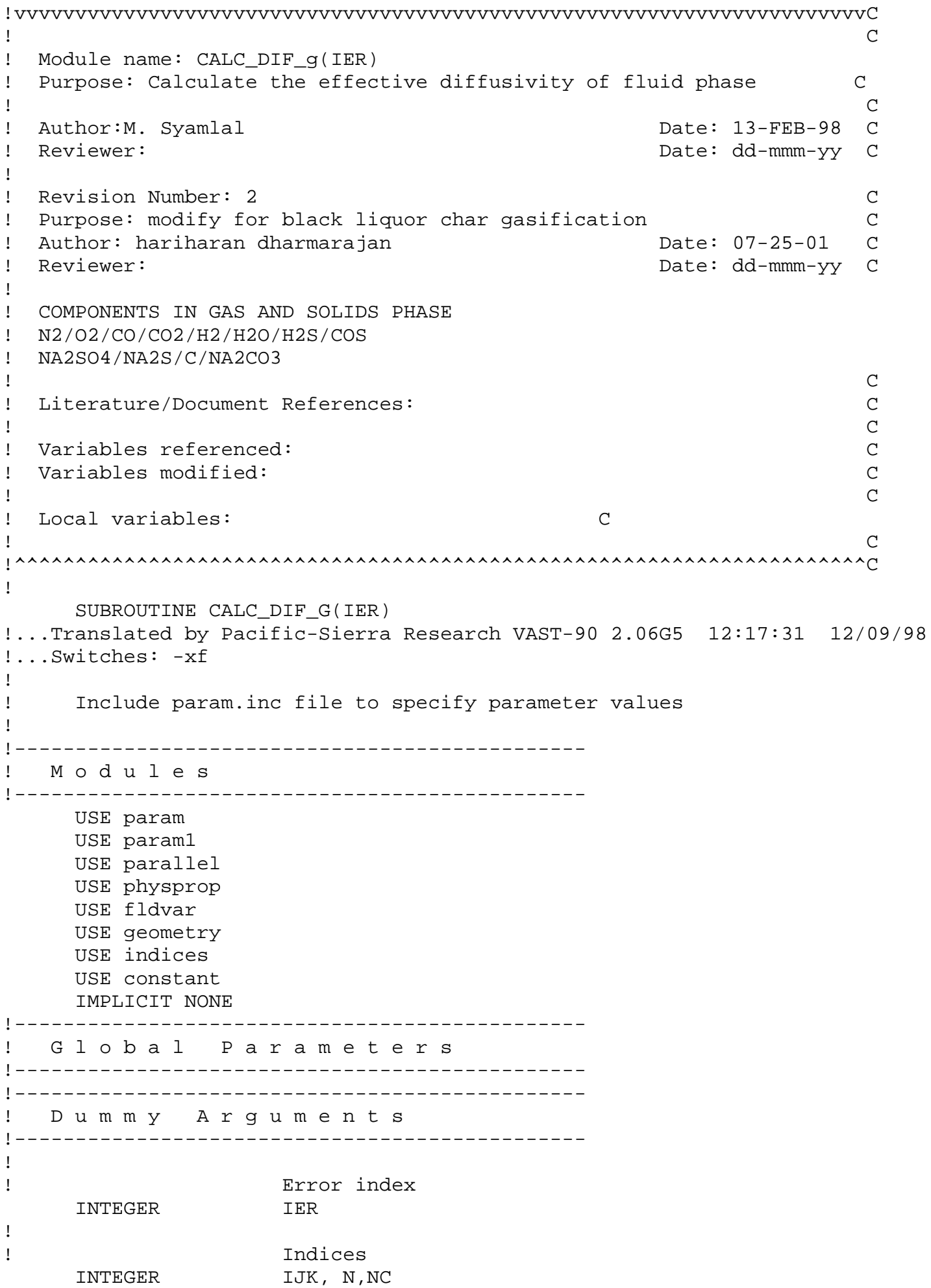


DOUBLE PRECISION UGC, VGC, WGC, USCM, VSCM, WSCM, VREL, RE, TS1, TG1, EPG1

INTEGER IMJK, IJMK, I JKM, I

!

INCLUDE 'function.inc'

INCLUDE 'fun_avg1.inc'

INCLUDE 'fun_avg2.inc'

IF (DIF_GO /= UNDEFINED) RETURN

!! \$omp parallel do private(ijk) \&

!! \$omp\& schedule (dynamic, chunk_size)

DO $N=1, \operatorname{NMAX}(0)$

DO $I J K=1$, IJKMAX2

IF (FLUID_AT (IJK)) THEN

IF (X_g (IJK, N) .GT.0.0) THEN

$\mathrm{EPGI}=\mathrm{EP} \_\mathrm{g}(\mathrm{IJK})$

$\mathrm{TG1}=\mathrm{T} \_\mathrm{g}(\mathrm{IJK})$

$\mathrm{TS} 1=\mathrm{T} \_\mathrm{S}(\mathrm{IJK}, 1)$

IF (T_g (IJK).GT . (C (22) +300.0)) TG1=C (22) +300.0

IF (T_S $(I J K, 1) . G T .(C(22)+300.0)) T S 1=C(22)+300.0$

! Gas diffusion coefficient

!revised on $11 / 06$ assuming the bulk gas to be air

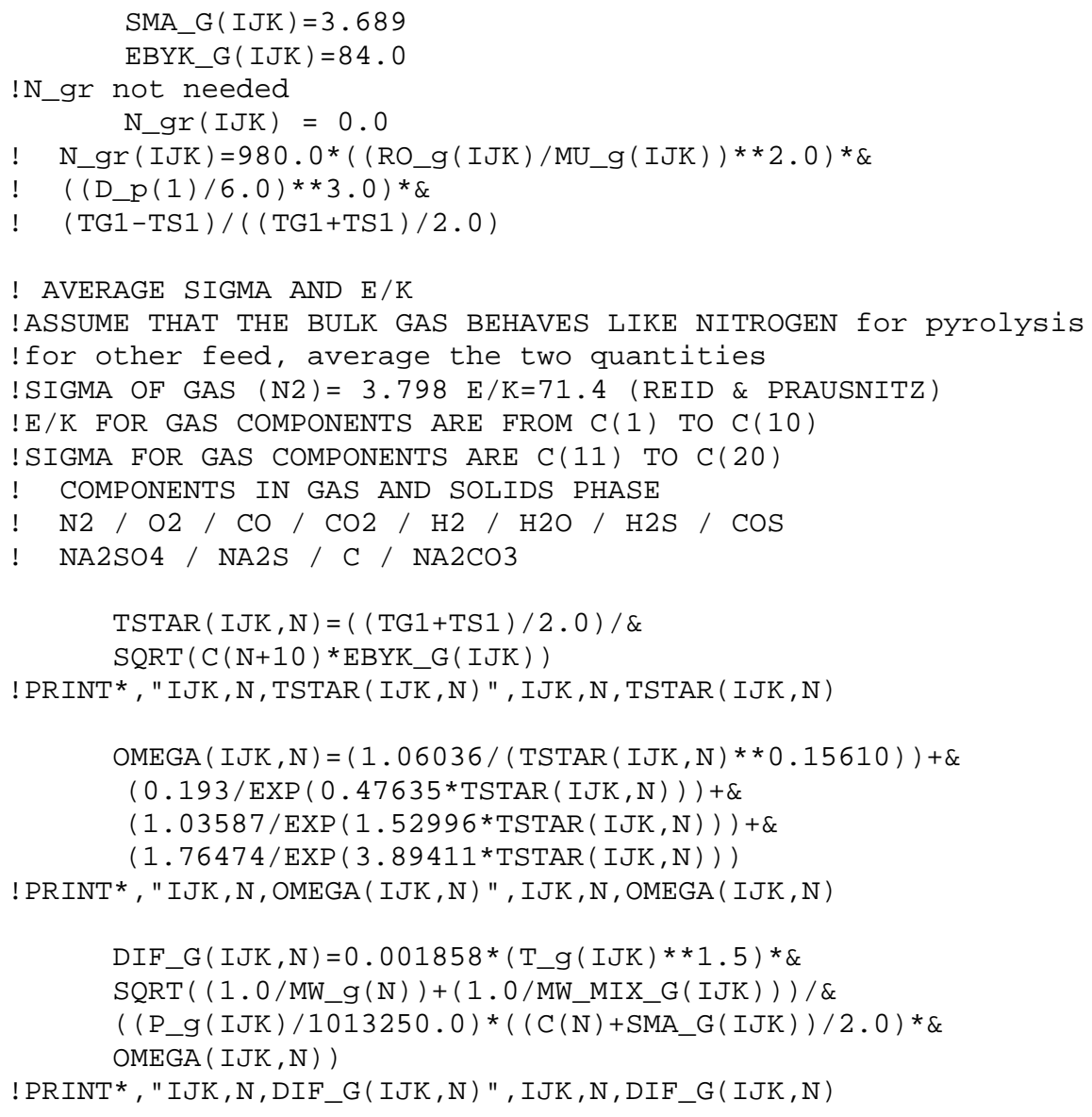




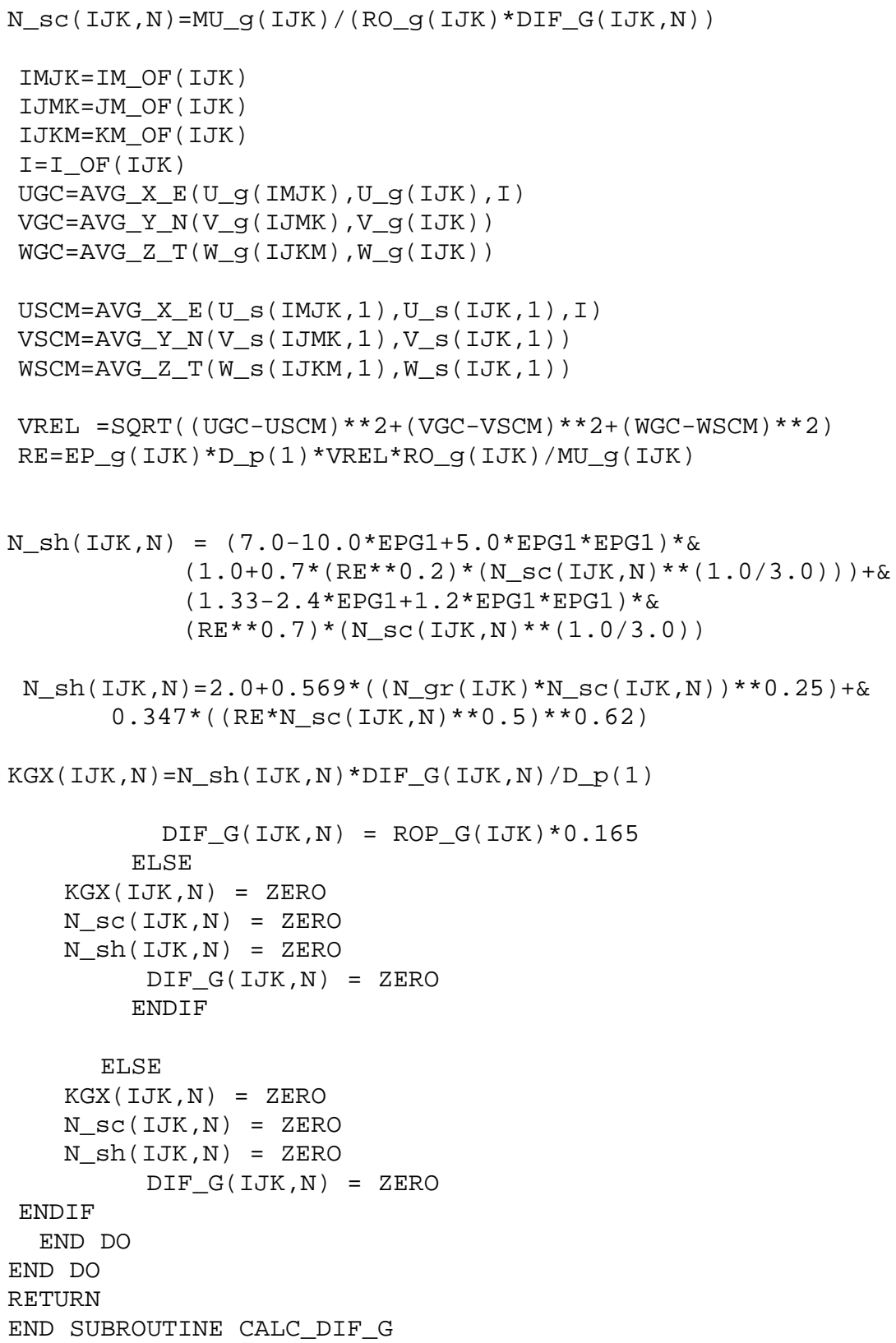




\section{APPENDIX E}

\section{Mfix.dat}

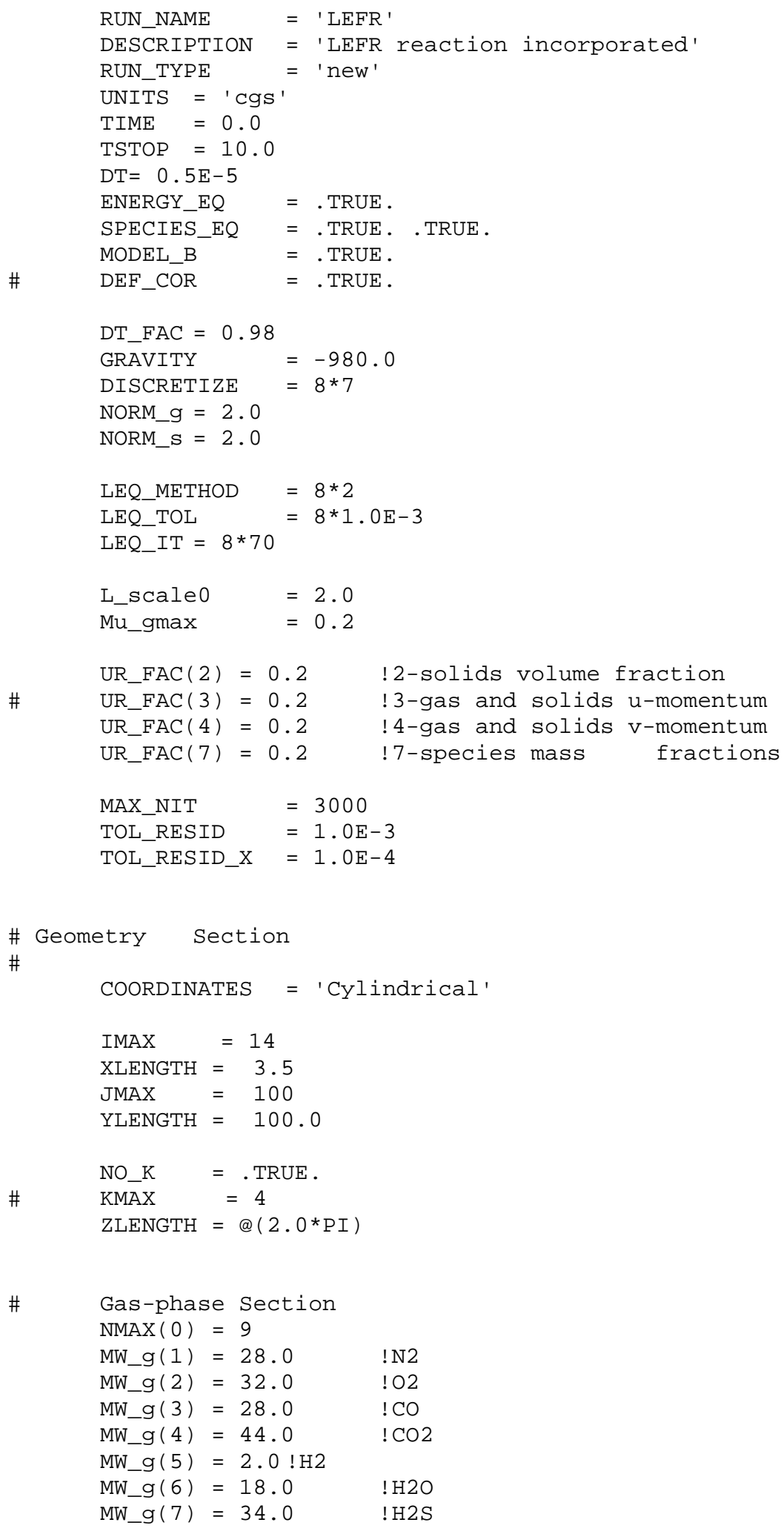




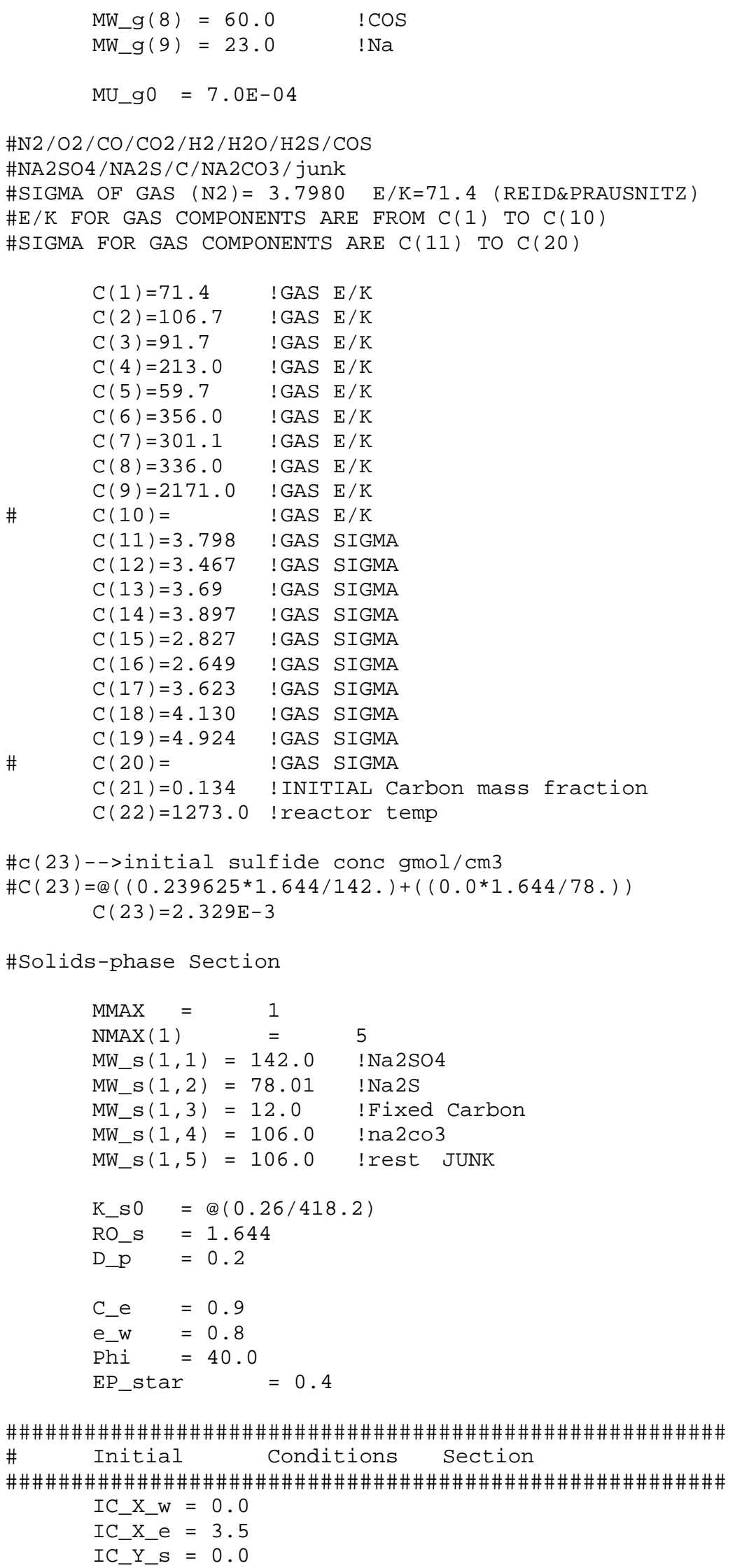




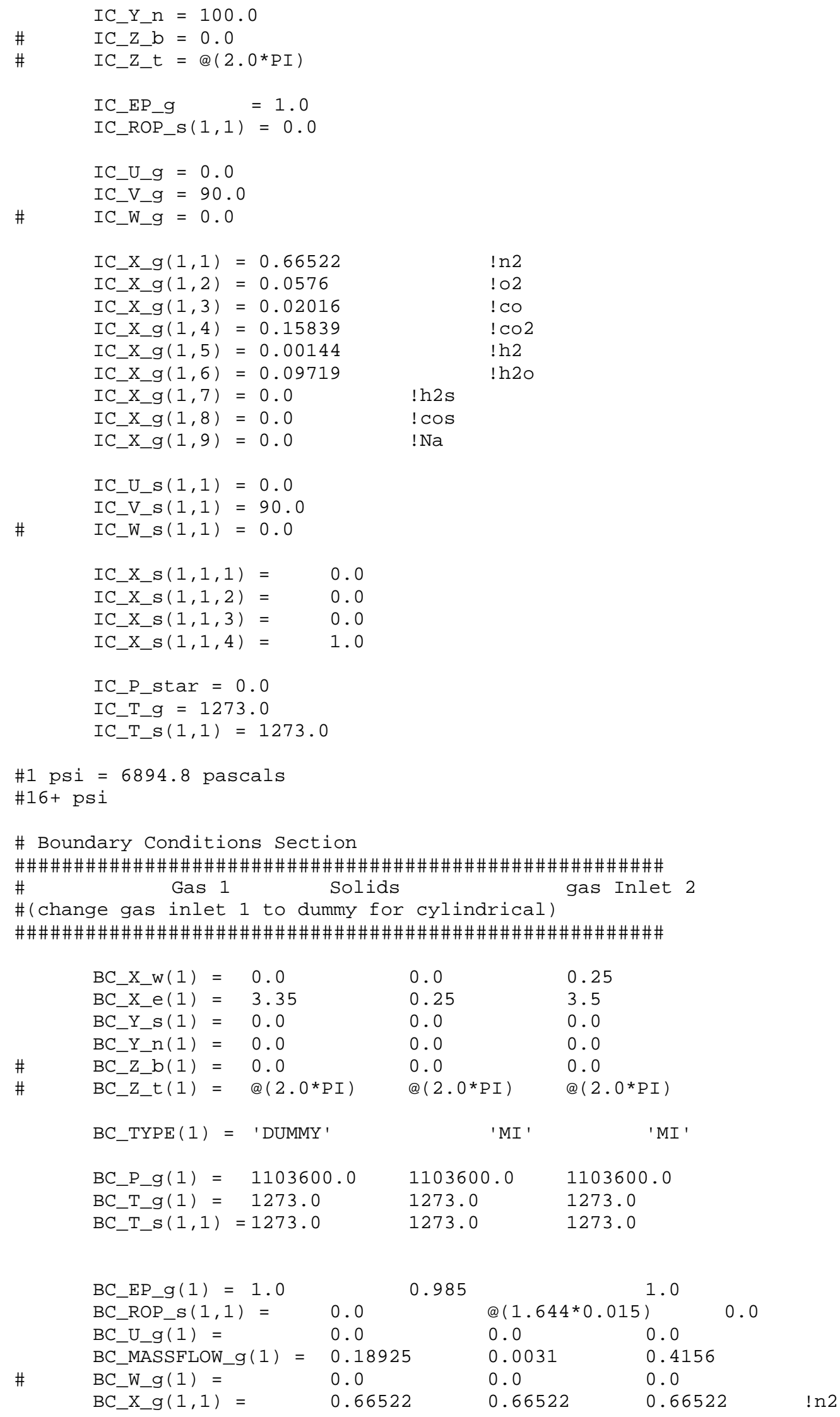




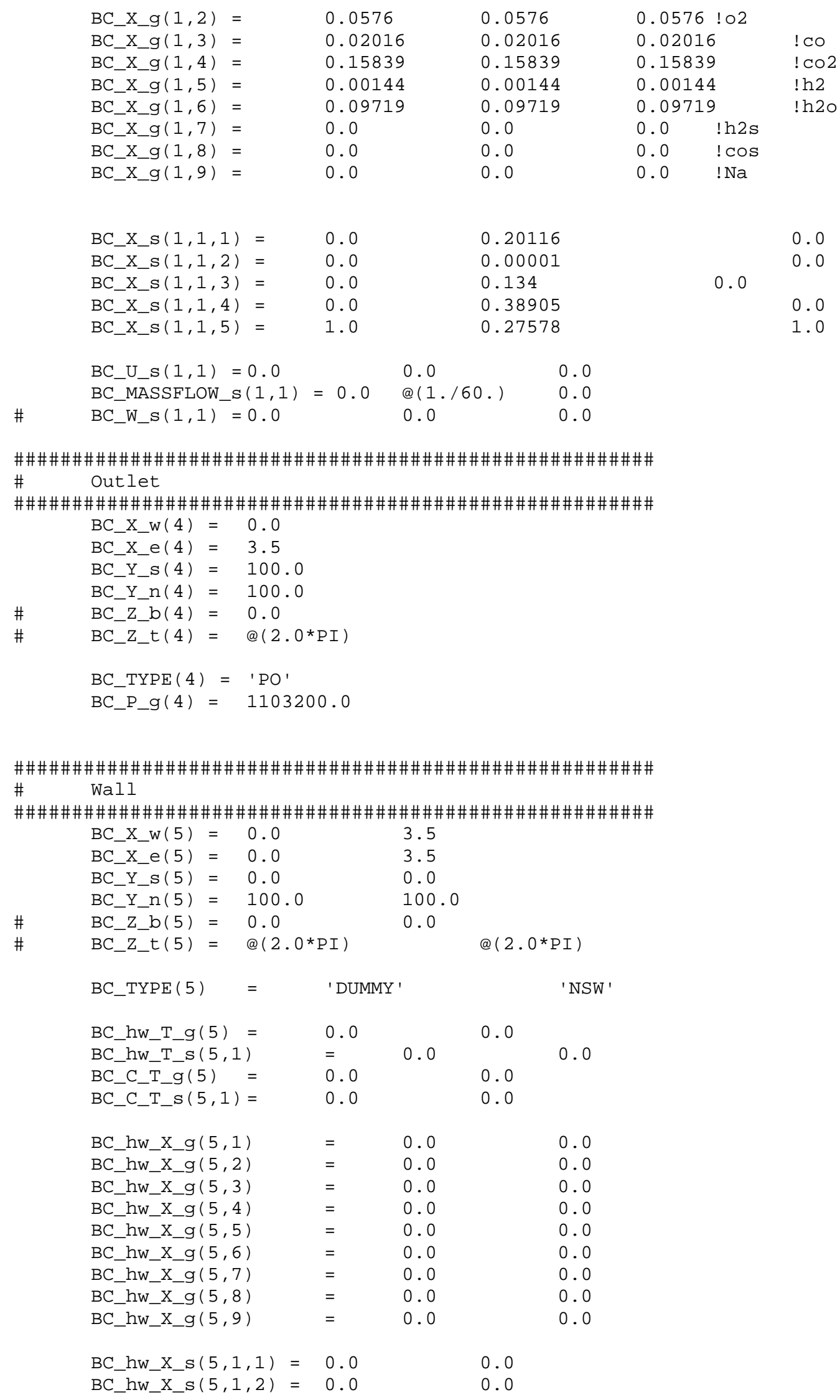




\begin{tabular}{|c|c|c|c|c|c|}
\hline \multicolumn{2}{|c|}{ BC_hw_X_s $(5,1,3)$} & $=$ & 0.0 & \multicolumn{2}{|l|}{0.0} \\
\hline BC_hw_X_s $(5$, & , 4) & $=$ & 0.0 & 0.0 & \\
\hline BC_hw_X_s (5, & ,5) & $=$ & 0.0 & 0.0 & \\
\hline BC_C_X_g $(5,1$ & $=$ & & 0.0 & 0.0 & \\
\hline BC_C_X_g $(5,2$ & $=$ & & 0.0 & 0.0 & \\
\hline BC_C_X_g $(5,3$ & & & 0.0 & 0.0 & \\
\hline BC_C_X_g $(5,4$ & $=$ & & 0.0 & 0.0 & \\
\hline BC_C_X_g $(5,5$ & $=$ & & 0.0 & 0.0 & \\
\hline BC_C_X_g $(5,6$ & $=$ & & 0.0 & 0.0 & \\
\hline BC_C_X_g $(5,7$ & $=$ & & 0.0 & 0.0 & \\
\hline BC_C_X_g $(5,8$ & $=$ & & 0.0 & 0.0 & \\
\hline BC_C_X_g $(5,9$ & & & 0.0 & 0.0 & \\
\hline BC_C_X_s $(5,1$ & & & $=$ & & 0.0 \\
\hline BC_C_X_s $(5,1$ & & & $=$ & & 0.0 \\
\hline BC_C_X_s $(5,1$ & & & $=$ & & 0.0 \\
\hline BC_C_X_s $(5,1$ & & & $=$ & & 0.0 \\
\hline BC_C_X_s (5, & $1,5)$ & $=$ & & & 0.0 \\
\hline BC_Tw_g (5) & $=$ & & 1273.0 & 1273.0 & \\
\hline BC_Tw_s $(5,1)$ & $=$ & & 1273.0 & 1273.0 & \\
\hline BC_T_g (5) & $=$ & & 1273.0 & 1273.0 & \\
\hline BC_T_S $(5,1)$ & $=$ & & 1273.0 & 1273.0 & \\
\hline
\end{tabular}

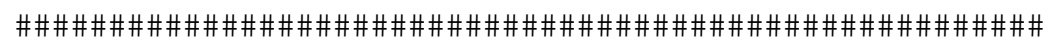
\#OUTPUT CONTROL SECTION

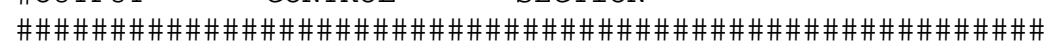

$\begin{array}{lll}\text { RES_DT }= & 0.005 & \\ \text { OUT_DT }= & 10.0 & \\ \text { SPX_DT }= & 8 * 0.01 & 100.0 \\ \text { USR_DT }(1) & = & 0.1 \\ \text { NLOG }= & 50 & \\ \text { \#FULL_LOG }= & \text {.TRUE. }\end{array}$




\section{APPENDIX F}

\section{Heat Capacities and Heats of Formation}

$$
\begin{aligned}
& \mathrm{Cp}^{\circ}=\mathrm{A}_{1}+\mathrm{B}_{1} \times \mathrm{t}+\mathrm{C}_{1} \times \mathrm{t}^{2}+\mathrm{D}_{1} \times \mathrm{t}^{3}+\mathrm{E}_{1} / \mathrm{t}^{2} \quad \text { (Shomate Equation) [33] cal/gmolK } \\
& \mathrm{H}^{\circ}-\mathrm{H}^{\circ}{ }_{298}=\mathrm{A}_{1} \times \mathrm{t}+\mathrm{B}_{1} \times \mathrm{t}^{2} / 2+\mathrm{C}_{1} \times \mathrm{t}^{3} / 3+\mathrm{D}_{1} \times \mathrm{t}^{4} / 4-\mathrm{E}_{1} / \mathrm{t}+\mathrm{F}_{1}-\Delta \mathrm{H}_{f, 298}^{\circ} \quad \text { [33] kcal/gmol }
\end{aligned}
$$

Table A-1. Constants for Shomate Equation.

\begin{tabular}{|c|l|l|l|l|}
\hline & \multicolumn{1}{|c|}{$\mathrm{Na}_{2} \mathrm{SO}_{4}$} & \multicolumn{1}{|c|}{$\mathrm{Na}_{2} \mathrm{~S}$} & $\mathrm{C}$ & $\mathrm{Na}_{2} \mathrm{CO}_{3}$ \\
\hline $\mathrm{A}_{1}$ & 36.83951 & 13867.88 & $\mathrm{C}_{\mathrm{p}}=2.553 \mathrm{cal} / \mathrm{molK}$ & -255.0191 \\
\hline $\mathrm{B}_{1}$ & 2.92774 & -25021.27 & & 590.1864 \\
\hline $\mathrm{C}_{1}$ & 11.8052 & 16739.29 & & -437.1558 \\
\hline $\mathrm{D}_{1}$ & -3.686791 & -3913.671 & & 120.8767 \\
\hline $\mathrm{E}_{1}$ & -0.045462 & -1650.069 & & 23.94407 \\
\hline $\mathrm{F}_{1}$ & -341.407 & -7681.405 & & -145.1061 \\
\hline $\mathrm{G}_{1}$ & 81.2326 & 17179.3 & & -324.1969 \\
\hline $\begin{array}{c}\Delta \mathrm{H}^{\circ}{ }_{\mathrm{f}, 298} \\
(\mathrm{kcal} / \mathrm{mol})\end{array}$ & -330.043 & -87.5 & 0.0 & -270.2605 \\
\hline
\end{tabular}

\begin{tabular}{|c|l|l|l|l|}
\hline & \multicolumn{1}{|c|}{$\mathrm{N}_{2}$} & \multicolumn{1}{c|}{$\mathrm{O}_{2}$} & \multicolumn{1}{c|}{$\mathrm{CO}$} & \multicolumn{1}{c|}{$\mathrm{CO}_{2}$} \\
\hline $\mathrm{A}_{1}$ & 6.236138 & 7.088672 & 8.401219 & 13.9021 \\
\hline $\mathrm{B}_{1}$ & 1.964341 & 1.466841 & 0.31073 & 0.650113 \\
\hline $\mathrm{C}_{1}$ & -0.472309 & -0.283585 & -0.049216 & -0.11766 \\
\hline $\mathrm{D}_{1}$ & 0.038067 & 0.022892 & 0.003239 & 0.009284 \\
\hline $\mathrm{E}_{1}$ & 0.01062 & -0.052501 & -0.784603 & -1.540941 \\
\hline $\mathrm{F}_{1}$ & -1.909472 & -2.356929 & -30.5539 & -101.797 \\
\hline $\mathrm{G}_{1}$ & 52.82505 & 56.87094 & 55.3805 & 63.0049 \\
\hline $\begin{array}{c}\Delta \mathrm{H}_{\mathrm{f}, 298} \\
(\mathrm{kcal} / \mathrm{mol})\end{array}$ & 0 & 0 & -26.41661 & -94.05411 \\
\hline
\end{tabular}

\begin{tabular}{|c|l|l|l|l|}
\hline & \multicolumn{1}{|c|}{$\mathrm{H}_{2}$} & \multicolumn{1}{c|}{$\mathrm{H}_{2} \mathrm{O}$ vapor } & \multicolumn{1}{c|}{$\mathrm{H}_{2} \mathrm{~S}$} & \multicolumn{1}{c|}{ COS } \\
\hline $\mathrm{A}_{1}$ & 8.160469 & 7.192161 & 12.2422 & 14.4174 \\
\hline $\mathrm{B}_{1}$ & 0.120441 & 1.633011 & 0.991273 & 0.415471 \\
\hline $\mathrm{C}_{1}$ & 0.088919 & 1.62367 & -0.153816 & -0.050187 \\
\hline $\mathrm{D}_{1}$ & -0.009225 & -0.605755 & 0.009948 & 0.003372 \\
\hline $\mathrm{E}_{1}$ & -1.929914 & 0.019632 & -2.500921 & -1.225831 \\
\hline $\mathrm{F}_{1}$ & -5.071415 & -59.962 & -13.3547 & -40.30371 \\
\hline $\mathrm{G}_{1}$ & 38.74116 & 53.39309 & 58.24331 & 68.7489 \\
\hline $\begin{array}{c}\Delta \mathrm{H}_{\mathrm{f}, 298} \\
(\mathrm{kcal} / \mathrm{mol})\end{array}$ & 0 & -57.7979 & -4.900101 & -33.08009 \\
\hline
\end{tabular}




\section{REFERENCES}

1. Frederick W. J "Combustion Processes in Black liquor Recovery: Analysis and Interpretation of Combustion Rate Data and an Engineering Design Model", US DOE Report DOE/CE/40637-T8 (DE90012712) (Mar. 1990).

2. Clay, D.T., Lien, S.J., Grace, T.M., Macek, A., Amin, N., Semerjian, H.G. And Charagundla, S.R., "Fundamental Study of Black Liquor Combustion." Report No. 2Phase 1, US DOE DOE/CE/40637-T2 (DE88005756) (Jan. 1987).

3. Clay, D.T., Lien, S.J., Grace, T.M., Macek, A., Amin, N., Semerjian, H.G. And Charagundla, S.R., "Fundamental Study of Black Liquor Combustion." Report No. 3Phase 1,2, and 3 US DOE DOE/CE/40637-T7 (DE89014547) (Apr. 1989).

4. Frederick, W.J. and Hupa, M., "Combustion Properties of Kraft Black Liquors", Department of Energy Report, DOE Contract No. DE-FGO2-90CE40936 (1993).

5. Frederick. W J., Lisa, K., Wåg, K. J., et al., "Sodium and Sulfur Release and Recapture During Black Liquor Burning". U.S. DOE Report DOE/CE/40936- T2 (DE96006558).

6. Wåg, K.J., Frederick, W.J., Grace, T.M. and Kymäläinen, M., "Sulfate Reduction and Carbon Removal During Kraft Char Burning", 1995 International Chemical Recovery Conference, Canadian Pulp and Paper Association, p.B35 (1995).

7. Kymäläinen, M., Janka, K., Frederick, W.J., et al., "Sulfate reduction in an Entrained Flow Black Liquor Gasifier", 1995 TAPPI-CPPA International Chemical Recovery Conference, Toronto, Canada, Paper 7 b6 (1995).

8. Sricharoenchaikul, V., Frederick W. J. Jr. and Grace, T.M., "Sulphur Species Transformations During pyrolysis of Kraft Black Liquor", Journal of Pulp Paper Science 23(8):J394--J400 (1997).

9. Sricharoenchaikul, V., Frederick W. J. Jr. et al., "Pyrolysis of Kraft Black Liquor: Formation and Thermal Conversion of Volatile Products and Char", Journal of Pulp Paper Science 24(2):43-50 (1998).

10. Reis, V. V., Frederick, W. J., Wåg, K. J., et al., "Mathematical Model for the Release of Inorganic Emissions during Black Liquor Char Combustion", TAPPI Journal 80(5): 135-145(1997).

11. Li, J. and van Heiningen, A.R.P -. "Kinetics of $\mathrm{CO}_{2}$ Gasification of Fast Pyrolysis Black Liquor Char", Industrial Engineering Chemistry Research 29(9): 1776-1785 (1990). 
12. Verrill, C.L., Grace, T.M. And Nichols, K.M., "The Significance of Sodium Release During Devolatilization on Fume Formation in Kraft Recovery Furnaces", Journal Pulp Paper Science 20(12): J354-J360 (1994).

13. Frederick, W J. and Hupa, M., "Gasification of Black Liquor at Elevated Pressures", TAPPI Journal, 74(7): 177-184 (1991).

14. Demirbas et al., "Kinetics for Low Temperature Pyrolysis of Black Liquor", Fuel Science and Technology International, 10(2), 185-197 (1992).

15. Bhattacharya, P., et al., "Pyrolysis of Black Liquor Solids", Ind. Eng. Chem. Proc. Des. Dev. 25: 420-426 (1986).

16. Bhattacharya, P., et al., "Pyrolysis of Black Liquor", Journal of Chemical Technology. Biotechnology. 35A: 223-233 (1985).

17. Van Heiningen, A.R.P., et al., "Effect of Liquor Type and Pyrolysis Rate on the Steam Gasification Reactivities of Black Liquors", Pulp and Paper Canada, 95(9): 5560 (1994).

18. Verrill, C.L., et al., "Detailed Black Liquor Drop Combustion Model for Predicting Fume in Kraft Recovery Boilers", TAPPI Journal 81(9): 139-148 (1998).

19. Whitty, K., R. Backman, et al., "An Empirical Model for Black Liquor Char Gasification as a Function of Gas Composition and Pressure", AICHE Symposium Series, 90(302): 73-84 (1994).

20. Mikkanen, P., et al., "The Particle Size and Chemical Species Distributions of Aerosols Generated in Kraft Black liquor pyrolysis and Combustion", AICHE Symposium Series, 90(302): 46-54 (1994).

21. Frederick W. J. Jr., et al., "Effect of Temperature and Residence Time on the Distribution of Carbon and Nitrogen Between Gaseous and Condensed Phase Products from Low Temperature Pyrolysis of Kraft Black Liquor", AICHE Symposium Series, 95(322): 119-127 (1999).

22. Salmenoja K., et al., "Studies on Black Liquor Gasification", AICHE Symposium Series, 90(302): 85-94 (1994).

23. Cameron, J.H. and T .M. Grace, "Kinetic Study of Sulfate Reduction with Kraft Black Liquor Char", Ind. Eng. Chem. Fundamentals 24(4): 443 (1985).

24. Li, J. and Van Heiningen, A.R.P., "Kinetics of Gasification of Black Liquor Char by Steam”, Ind. Eng. Chem. Res. 30(7): 1594-1601 (1991). 
25. Li, J, Van Heiningen, A.R.P "Sulphur Emission During Slow Pyrolysis of Kraft Black Liquor", TAPPI Journal 1.74(3): 237-239 (1991).

26. Li, J., "Rate Processes During Gasification And Reduction Of Black Liquor Char", Ph.D. thesis, McGill Univ., Montreal, October 1989.

27. Reid, R.C., Prausnitz, J.M. and Poling, B.E., "The Properties of Gases and Liquids", Fourth ed., McGraw-Hill Book Company, New York (1987).

28. Treybal, R.E., "Mass Transfer Operations", Third Edition, McGraw-Hill Book Company, New York, (1981).

29. Wåg K.J, “Characterization and Modeling of Black Liquor Char Combustion”, Ph.D. thesis, Oregon State University, Corvallis, October 1996.

30. Perry, R.H, et.al. "Perry's Chemical Engineering Handbook", $7^{\text {th }}$ Edition, McGrawHill Book Company, New York, p.5-48, 49, 1997.

31. Smook G.A., et al., "Handbook for Pulp and Paper Technologists". TAPPI, Atlanta. 1982.

32. Syamlal M., et al., "MFIX Documentation, Theory Guide", DOE/METC-94/1004 (DE94000087), U.S DOE, Morgantown, 1993.

33. Chase, M.W., Jr., "NIST-JANAF Thermochemical Tables", Fourth Edition, J. Phys. Chem. Ref. Data, Monograph 9, 1998, 1-1951. (http://webbook.nist.gov/chemistry)

34. Syamlal M., et al., "MFIX Documentation, Numerical Technique", DOE/METC94/1004 (DE94000087), U.S DOE, Morgantown, 1993.

35. Gidaspow, D., Multiphase Flow and Fluidization, Academic Press, Inc., 1994.

36. Gunn, D.J., "Transfer of Heat or Mass to Particles in Fixed and Fluidized Beds." Int. J. Heat Mass Transfer, 21, 467-476, 1978. 